\title{
Assessment of Water Resources for Nuclear Energy Centers
}

\author{
G. Samuels
}




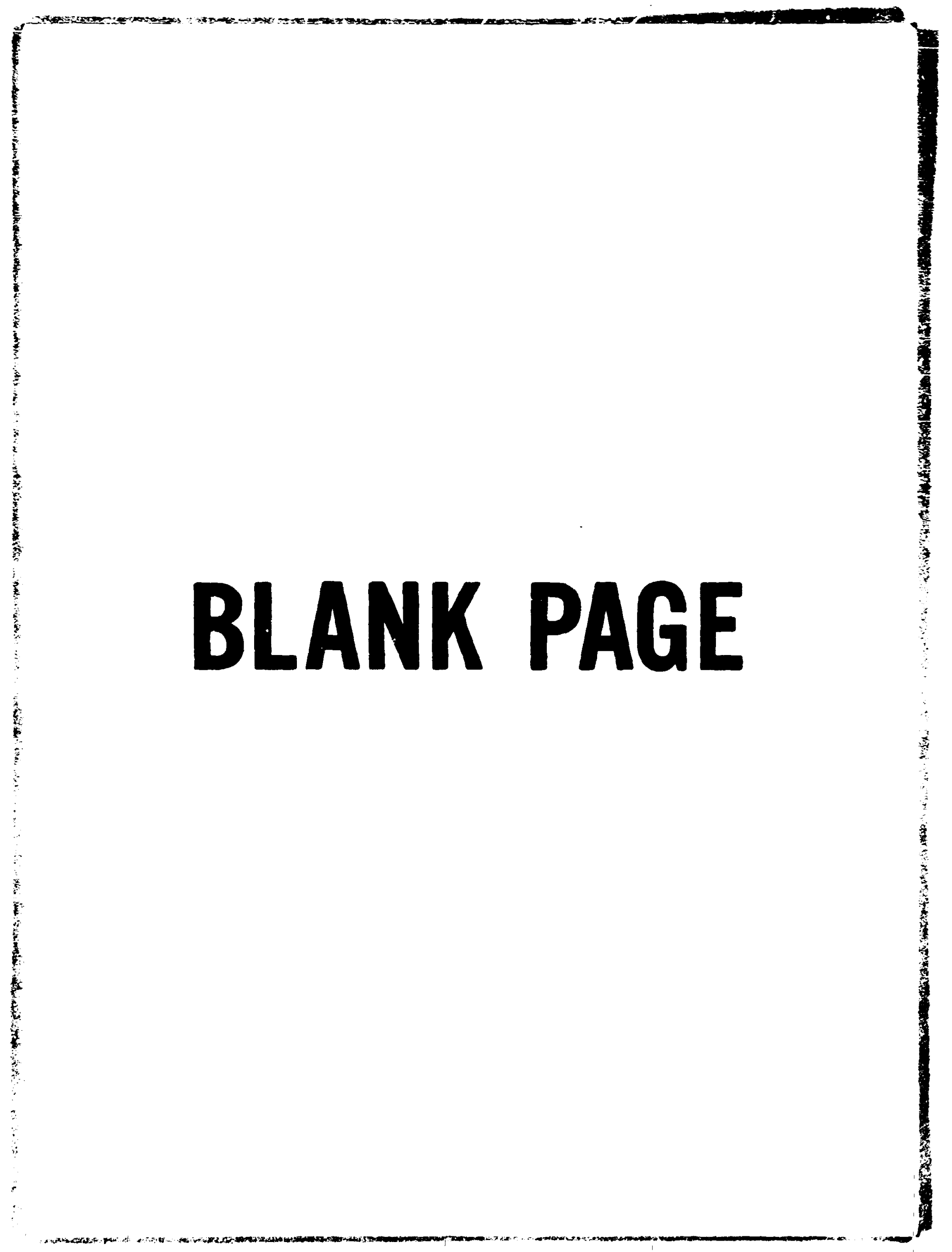


Prinied in the Un:ted States ut Amprica Arzidabe trom

Nai:onal Texhnicai frifurmation Servica

U.S. Department of Cumne ete

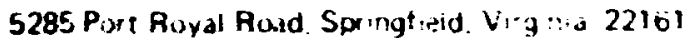

Price Pinted Cocy \$5 50. Pdicrot : he \$2 25

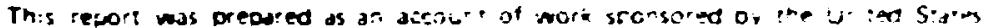

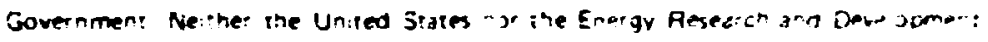

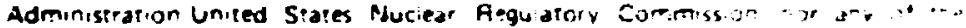

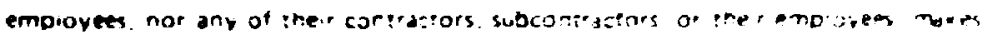

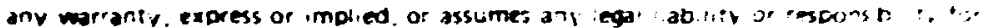

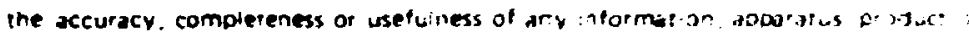

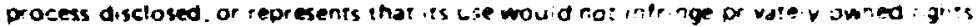


Cont ract No. $4-7405-e n 8-26$

EXECY DIIISION

ASSESSTEST OF WATER RESURTCES FOR MECLAR ENERGY CEXTERS

r. Samels

SEPTEMBER 1976

This scudy was performed for the Nuclear Regulatory Comission in connection with the developant of their Nuclear Energy Center site Survey repott to Congress.

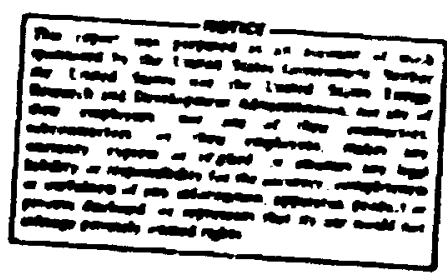

GAK RIDCE MATIOHAL LABORATORY

Dak Ridge. Tennessee 37830 operated by

INION CARBIDE CORPORATION

for the

FNERGY RESEARCH AND DEVELOPYENT ADMINISTRATION

or N-7405 ENG-26 
1. IxTmodiction

2. COASURTIVE hatER ISE ..................

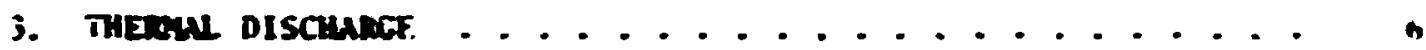

4. Hater cialtí . . . . . . . . . . . . . . . . in

5. HATER RESUURCES ASD PRUECTED DEUND .............. Is

3.1 Hater Resouries. . . . . . . . . . . . . . 11

3.2 Deand Profecrloos ................

b. Reservolr coastockAitoss . . . . . . . . . . . . B:

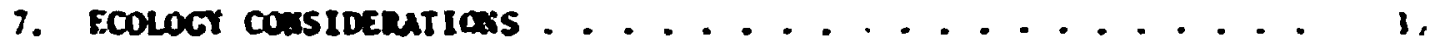

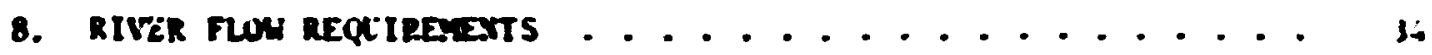

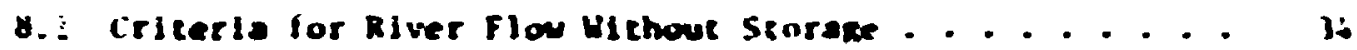

B.2 Cricerta fur River flon with blorage . . . . . . . 3i

9. Riter flow rates . . . . . . . . . . . . . . . . is

9.1 bata Suurces. Lialeatlons, and incerptetartons . . . . ti

9.: Power Capaciey of hajor River kasina . . . . . . . . i:

10. Reglonal Warer Resouries and Requirementx ......... ST

10.1 Sortheast Reglon ................. Sn

10.2 Middlo At Jantic Reglun ............... hi

10.1 South delantic Reglun ............... hh

10.. Florida Region................... as

lo.s South central florida ................ II

10.6 Miduest Rexion................. il

10.7 Surthern Cireat wakes Region ............. il

10.8 Cerseal Plaíns keglon ............... i it

10.9 Southwast kugion.................. M

10.10 Norethwest Rection................... ns

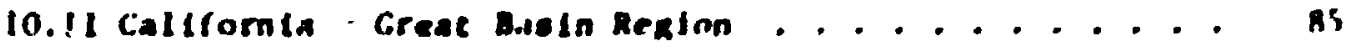

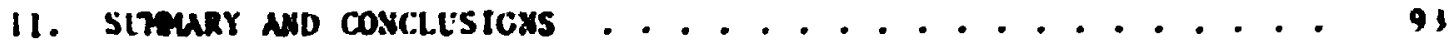

APPEXDIX ...................... . . . . . . . .

REFERENCES. . . . . . . . . . . . . . . . 99 
Fonanges

Section 207 of the Easray Reorganizat lou Act of 1974 requited the nuclear Regulatory Comisaion to conduct a nuclear eanery center site survey and report its findines to the congreas and the conacil of Enviromental Oadity. The Survey iacluded a semeral screenin of the 48 contiguous States to ideatify large land areas that could be likely to contain sites poteatially suicable for muclear emerey centers. It evaluated the techaical and practical considerations involved in locatIne the production of electric powet at a muclear earers center and comared these considerat loas with thoce involved in prodecins an equivalewt sovat of pourer at diepersed sices.

This accougt of the ascesswent of witer resoutces for auclear eneres ceaters he been developed as part of the techafical banis for the

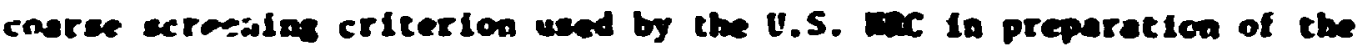
mecss-7s teport to Congreas. Weither this accovat wor the criterls ued

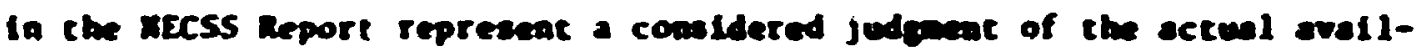
ability of wier or the eaviromental inpact of a specitic cencer inich wighe be proposed. Dather. the daca presented berela represenc an overviaw of the scope of problen and interactions wheh atght be eacountered should circunsturces dictate a deeper exealantion of the feastbitity and practicalley of a epectflc eaclear energy ceacer. 


\begin{abstract}
ASTTRACT
Maps of the conceninous lnited States showing the rivers with sufficient flow to be of interest as potential sites for nuclesr energy centers are presented. These uaps show the rivers with (1) man annual flows greacer than $3000 \mathrm{cfs}$, with the flow rates ident if ied tor ranges of 3000 to 6000,6000 to $12,000,12,000$ to 24,000 , and greater than 24,000 cfs; (2) wathly. 20-year 100 flows greater than $1500 \mathrm{cfs}$, with the flow rates ident fified for ranges of 1500 to 3000 , 3000 to 6000,6000 to 12,000, and greacer than 12,000 cfs; and (3) annual, 20-year low flows greacer than $1500 \mathrm{cfs}$, with the flow rates ideat ified for ranges of 1500 to 3000,3000 to 6000,6000 to 12,000, and greater than 12,000 cEs.

Criteris relating river flow rates required for various size generating stations both fcr sites located on reservoirs and for sices without local storage of coolsa water are discussed. These criteria are wed is conjunction with plant weter consemption rates (based on bolh instantaceous peak and annual average usage rates) to estimate the installed penerating capacity that my be located at one site or within a river basin.

Projections of fucure power capacisy requitenents, future demand for vacer (boch vichdrawals and consuntion), and regions of expected wacer shorcages are also presenced.

Regional anps of water avaliability, based on annual, 20-year low flows, are also shows. The feasibillty of locating latge enprgy centers in these regions is discussed.
\end{abstract}




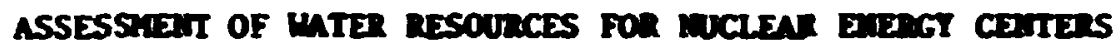

\section{Invosuction}

The purpose of this report is to discuss vater supply vs requirenents for the United States, with a vies toward ideatifying areas that have potential water resources sufficient to support mulear energs ceaters (AECS). I This report does not discuss social or institutional restraints on, or national priforities for, the use of wer or the developent of wier resources. There are areas of the United States that have, or are projected to have, serious water supply problems, and these areas are identif ied. The approach taken is to comple iaformtion on vater resources as they curreatly exist, from wich those areas with sufficient weter to wartant furcher evaluation are enpped.

Although wECs are defined is imetallations of 10 or more reactors, the water resource aps of this section also show those rivers with sufficient flow to be of interest for andler s- to 10-unit power atations. The resson for including ibe sivers with lower flows is that woter way be puped sone distance to sufply an we. Thus, to rivers within a shart distance of each other, each with suff icieat flow to support 5 units, could be used to supply a 10-unit MfE. Also, the foclusion of rivers with lower flows gives imight as to the additionsl areas that my he aval'able for a saller pouner complex.

I.) perfore a survey of possible $\mathrm{EEC}$ sites, it is firat necesanty to establish criteris or guidelines for the WEC requitenents and fo: the necessaty resources to neet these requirenents. The water reguirenents for an BEC will depead on the type of cooling systen uad, which for this survey is aseund to be wet cooling towers. It is aiso as guned that the cooling water is draws from local surface waters and that some percentage of this intake is returned an blowdown from the NEC cooling system.

The vacer demand for a power plant cooling syatem can the expreased as a withdraval rate (the quantity taken from local sources) or as the consuptive use, which in this case is the quantity evaporated in the cooling towers. The difference between these quantities is the bioudown 
fron the oysted. Drift losece from the tower, although possibly ifportant from the viempolat of local exiromeatal effects, tave a negligible effect on weter requireneats. The ratio of the ofthdraval rate to the bloudoun rate is the concentration ratio, or the waltiple to which the inpurities in the intake miter are concentrated before being diacharged frow the cooline syete.

The consunptive we. In this cace the weter evaporated by the cooling systen. represents the demad placed on local weter rewources. The coscentration ratio has esseatialiy no effect on the anowe of water used. Bonever, this racto vill affect the hat aded to local surface witer and, depeading on the cooling water systen treacaeat witain the plant, wy affect che level of inpurities in the water. Doth of these are discuased lacer.

The asound nse of wet cooline turers reaults in a stenter eveporative use of cooling weter (about $40 \mathrm{f}$ greater) tha once-through gysces. The differeace in the evaporation rate between the tur ojuten is caused by the higher cepperature at ubict the cooling cakes place in a coolias touser. This higher caperature, and thos high seter vapor pressure, Increases the ratio of the anot of heat crabaferred by evaporation to that trameferted as sensible beat.

As ar aid to the reader, the definition of sone of the note commonly used h,drologic tern and conversion tables for units of volune and flow are given in the Appeadix. 


\section{COASURPTIVE WATER USE}

The quantity of water evaporated to reject a given acout of heat in a wet cooling tower will depeod on the wet-and dry-bulb temperatures and the water temperature to and from the cooling tower. Thus, the water demand w11 vary seasonally and from one location to another. The water denand will be bigbest during bot weacher, when afr and thus cooling weter teperatures are highest. In ast parts of the country having adequate fresh weter resources for an $\mathrm{ALC}$, about 80 to 852 of the heat is rejected by evaporation of the cooline vater during warn weather, and the renining 15 to 200 goes to raisias the cenperature of che air drawn through the cooling touer. If It is afsuned that this split of beat rejection is 852 by evaporation and 152 to the air and that the average wer teperature in the coollas tower is $100^{\circ} \mathrm{F}$ (lateat beat of evaporation, $1037 \mathrm{Btu} / \mathrm{Lb})$, the cotal beat rejected for each poud of wacer nvaporated is 1037/0.85, or 1220 Btu. The asout of water eveporatic $n$ for each kilowate of power senerated depends on the efficlency of the fwer plant, wich for weter reactors is about 1/3. Thus, for each kilowit generated, 2 hi (6826 Btu/hr) of bent wist be rejected. This requiles the evaporation of 5.6016 of water for each kilowatehour of electricity. Which Ifplles that a cyplesl 1200-ible weter reactor wil consunt a maxima of about $6,720,000$ ib of wer per hour (equivalent to about 3.) (fs). In actual operacios, sone and part of the heat (1 to 35) w1! be rejected by the blowdow from the plant. An wec of from ten co forty 1200-tive reactors would comene from 300 to 1200 cfs of water by esaporation. These water use rate are for warmmenther conditlons. During cold wether, a larger persentage of the heat is given to the air. and the water consuption rate w11 be less (about 75 to 852 of the sumer consuption rate in nost parts of the United States).

Typlcal performance curves for a nacural-draft cooling tower are given in Pig. I for a range (wacer teperacure change ia passing through the cooling tower) of $30^{\circ} \mathrm{F}$ and an abient air relative humidity of 702 . The air dry-bulb temperature is shom for reference purposes and is determined by the air wet-bulb ceperature and the resative huidity. The conling cower operating condictons are primartly decermined by the 


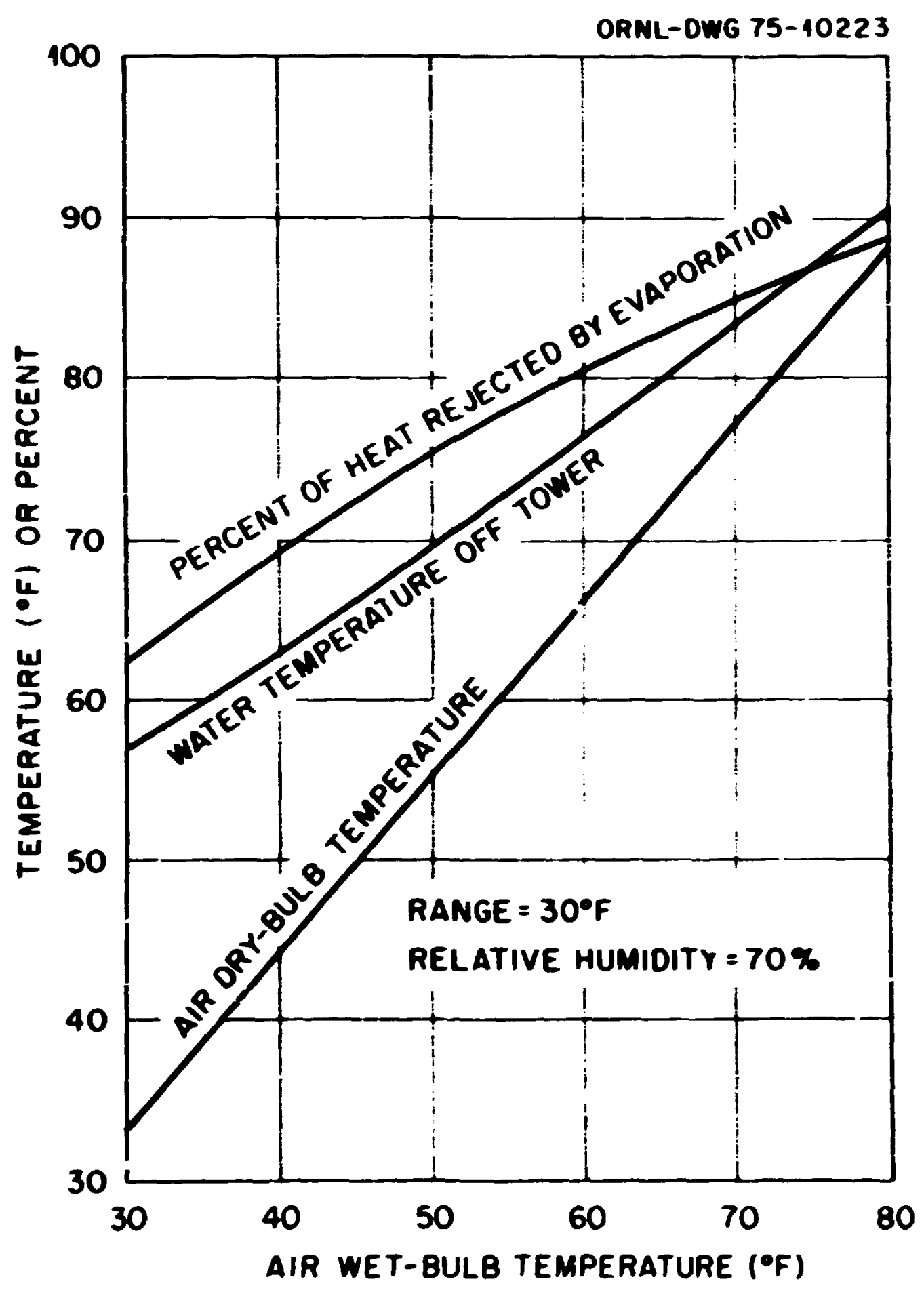

Fig. 1. Typical natural-draft cooling rover performance. 
wet-bulb temperature, with some saller influerce by the dry-bulb tecperature. The upper curve of Fig. I shows the variat ton of the percent of the heat rejected by evaporation as a function of the wetbulb temperature for the assuned range and relative huidity. The water cemperature off the comer is the temerature to which the vacer is cooled in passing through the coner. The difference between the water zemperature of $f$ the tower and the wet-bulb temperature is tine coner spproach.

Design air cepperacures vary widely across the counery, and the relat ive huidity of $70 \%$ used in sig. 1 is representacive of peak sumer anditioas, averaged over a 24-hr period, in the eastern part of the councry. Iyolcal simer day desigan dry-bulb cemperatures range tetween the upper 80's and upper 90's. Design wet-bulb terperatures are usually in the 70's, and the relative huddicy is about 50z. The day-to-aight dry-bulb temperature change is about $20^{\circ} \mathrm{F}$, and with a constant air wisture content, the wet-buib temperature decreases about $5^{\circ} \mathrm{F}$ and the relative huidity iacreases to about 90 . Tilus. peak 24 thr sumer condicioas are a wet-bulb cemperature in the low 20 's, a relative hunidity "I about 70;, and a corresposdine dry-bulb teeperature of about $80^{\circ} \mathrm{F}$. thout 85 or 86 ; of the hest is rejected by evaporation for these condiinons. For very hot arid areas, the percentage of heat rejected by evaporation is somewat greater, while for wre bueid conditsons or for cold wather, the hear rejec:ed by evaporation, is less.

The water temerature off the tower $\left(\mathrm{Fi}_{\mathrm{g}}\right.$. 1) shows a trend that can cause cheral discharge probles durias winter operation. As the air temperafure decteases, the wet temperature, which is al so the terperatcre of the pleat blowdoun strean, decreases, but at a slower rate. The river temperature also follow the air cemperature, and as the cower approach increases, so does the cemperature difference between the hlowoow strea and the river. Furthermore, the cooling cower responds to ir changes wuch wore rapidly then the river. A sudden air cemperature increase can lead to a rather large difference between the temperacures of the blowdown stream and the river and can rause a significant increase in the river cemperature. This is discussed in detall in the following section. 


\section{THERAAL DISCHARGE}

The thermal discharge or heat rejected to local surface waters with a cooling towe: systee depends on the concentration rat $: 0$ and is on the order of 1 to $3 \%$ of that typical of once-through run-of-river cooling. As aoted previously, the concentration ratio $R$ is equal to the withdrawal rate $W$ divided by the blowdown rate $B$, while the evaporation race $E$ is the differeace between the withdrawal and blowdown rate. Thus,

$$
\begin{aligned}
& E=W-B, \\
& R=W / B,
\end{aligned}
$$

and by substitution,

$$
E=R B-B=B(R-1) \text {. }
$$

or

$$
B=E /(R-1) .
$$

The rate of heat rejection by the blowdown, $Q_{b}$, is equal to the product of the blowdown rate, the heat cupacity, $C_{p}$, and the temperature difference, $\Delta T_{b}$, between the blowdown and the local water source. Thus,

$$
Q_{b}=B C_{p} \Delta T_{b}
$$

and

$$
q_{b}=E C_{p} \Delta T_{b} /(R-1) .
$$

Using a value of $E$ equal to $5.6 \mathrm{lb} / \mathrm{hr}$ for each kilowatt of electricity generated, $Q_{b}$ can be expressed in dimensionless form, $Q_{r}$, as the ratio of heat rejected to the power generated: 


$$
Q_{r}=0.00164 \Delta T_{b} !(R-1) \text {, }
$$

when $\Delta T_{b}$ is in degrees Fahrenheit. A graph of this equation is shown in Fig. 2. Another manner in which the thermal ef fects of blowdown can be expressed is the effect on the temperature of the receiving body of water. If the local water source is a river, then the temperature -ise in the river can be expressed as a function of the fraction of the river flow shat is evaporated, the concentration ratio, and the temperature difference between the blowdown f low and the river. If the river flow rate is $S$ and the increase in the average river temerature caused by the blowdown is $\Delta T$. (assuning instantaneous wixing at the polit of blowdown entry), then a heat balance gives

$$
(S-E) \Delta T_{S}=B \Delta T_{b}=E \Delta T_{b} /(R-1),
$$

or

$$
\Delta T_{S} / \Delta T_{b}=\frac{E}{(S-E)(R-1)}=\frac{E / S}{(1-E / S)(R-1)}
$$

where E/S is the fraction of the river flow evaporated and $\Delta T_{s} / \Delta T_{b}$ is the ratio of the river temperature rise to the blowdown temperature rise. A graph of this equation is shown in Fig. 3. The critical pertod for increases in the rive: temperature will be during relatively warm humid periods during the winter or early spring, when the river is cold. The blowdown $\Delta T_{b}$ during this time may be as high as $40^{\circ} \mathrm{F}$, and if the 1 imit on the increase in rijer cemperature is $4^{\circ} \mathrm{F}$, then a cooling system with a concentration ratio of 2 would be 11 inited to an evaporation rate of about 9\% of the river fluw rate. During the summer and early fall, the valuc of $\Delta T_{b}$ ill usually be smaller; however, limitations on the maximum allowable river temperacure, rather than the increase in river cemperature, may be a restriction. Thus, even with a wet cooling tower, the thermal discharge from the NEC may restrict the amount of water that can be used. 


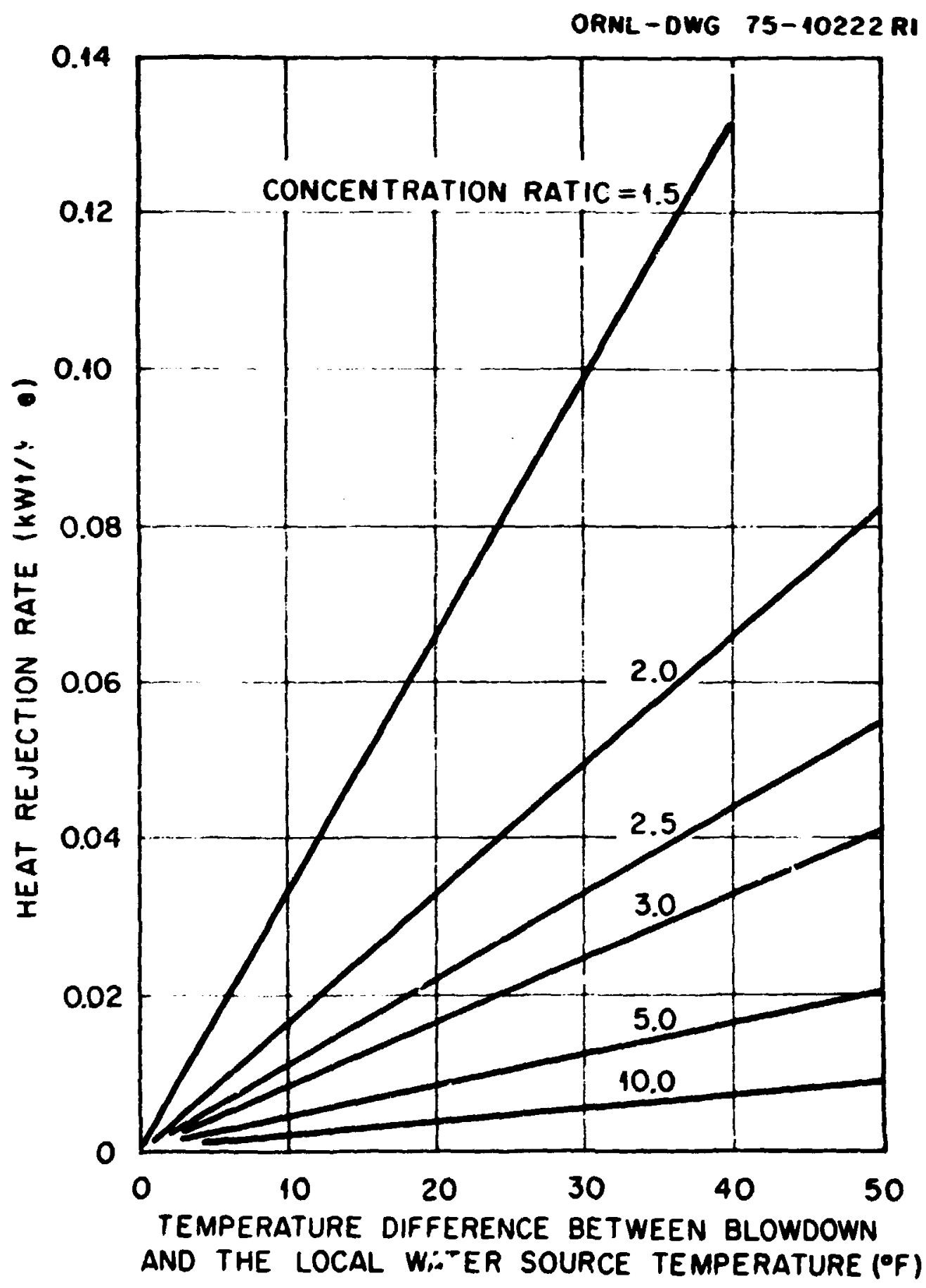

Fig. 2. Heat rejection rate as a function of the concentration ratio and the temperature difference between the blowdown and the local water source. 


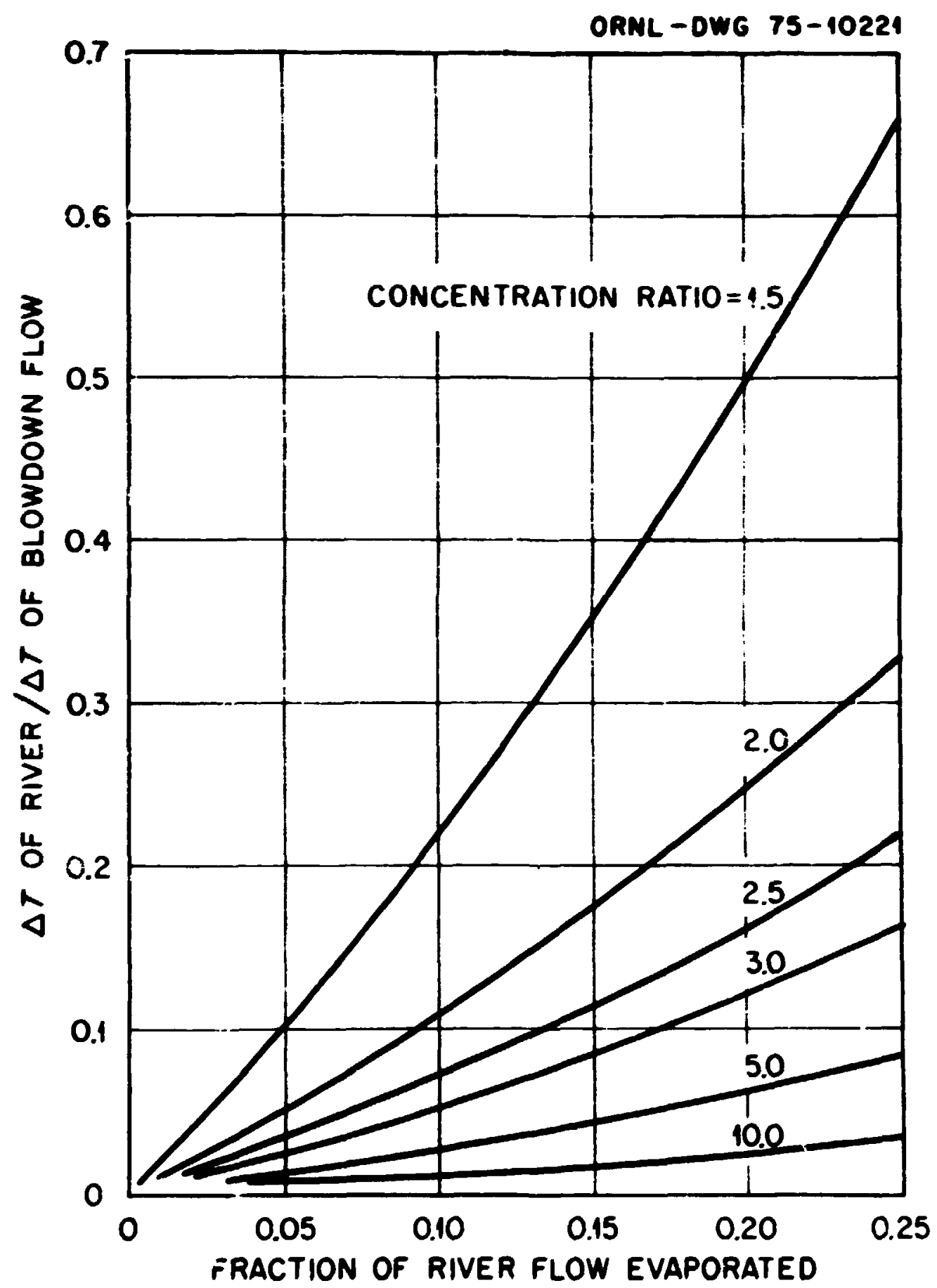

Fig. 3. Ratio of river temperature rise to blowdown temperature rise as a function of the fraction of the river flow evaporated and the concentration ratio. 


\section{HATER GUALITY}

Water quality must be evaluated for its intended use. For use in cooling towers, one is most concerned with the dissolved solids, especially those affecting the hardness of the water, and the suspended solids. Because of the wide variability of water qualiz; for cooling purposes throughout the country (as shown in Figs. 4 and 5$)^{2}$ and the variety of treatment thods available, the problems associated with water quality and treatment are site-dependent. Furtherwore, the effect of an NEC on the water quai iry for other purposes is also difficult to general,ze and requires site-specific data.

If the river water is used in the plan! cooing system without treatment, that is, without addition of chemicals or elimination of naturally occurring impurities, then the concentration ratio is a dirert measure of the degree to which the impurities are concentrated in the blowdown. However, the sencentration ratio has no effect on the total quantity of impurities in the river downstrean from the point of blowdown return. Because the total quantity of impurities is the same downstrean as at the point of water withdrawal, the increase in the concentration (outside of a local mixing zone) is proportional to the derrease in the river flow, and the decreased flow depends almost cotally on the evaporation rate. For cooling systems without blowdown, where all of the water withdrawn is evapurated on site, the concentration of impurities is unchanged. However, the water consumed by the plant may have an adverse effect on downstream quality because of the reduced flow available to dilute wastes added to the river. In current practice, practically all evaporative cooling systems use blowdown and some form of chemical treatment. The cooling system concentration ratio depends on the local water quality and the water treatment used and should be evaluated on a site-by-site basis.

Much of the current concern about water quality Involves the addition of wastes to rivers and the effect of these wastes on the oxygen content of the water. As noted by Burwell, ${ }^{3}$ cooling towers are effective water aerators and will be beneficial in this respect. A detailed study of current and projected water quality problems in the inited states is given by Wollman and Bonem" and is discussed later. 


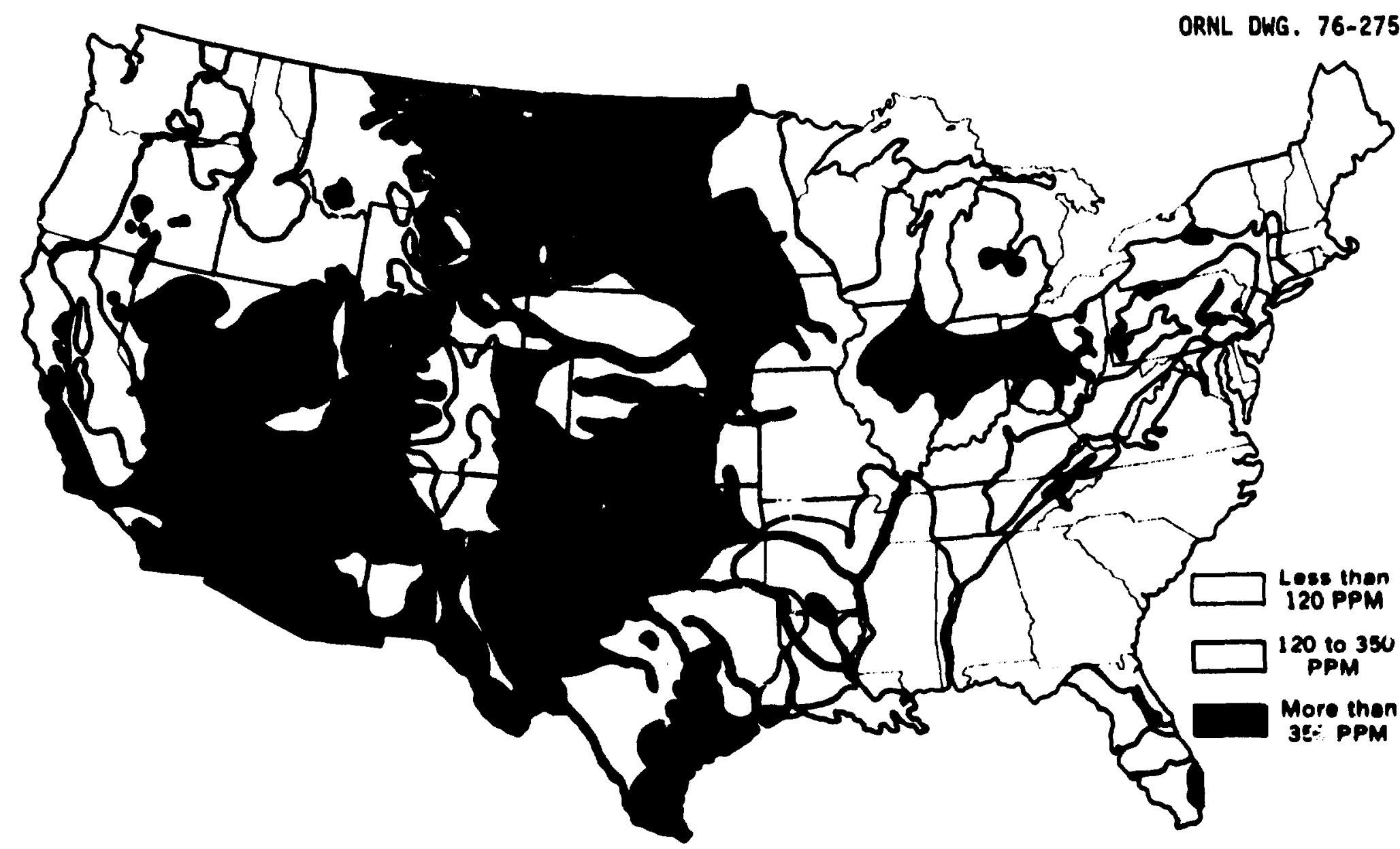

F18. 4. Concentration of dlesolved ocllde In etreamflow. Source: U.S. Water Resources Counc11, The Nation's Water Resouroes, U.S. Governaent Printins Offlce, Washington, D.C., 1968. 


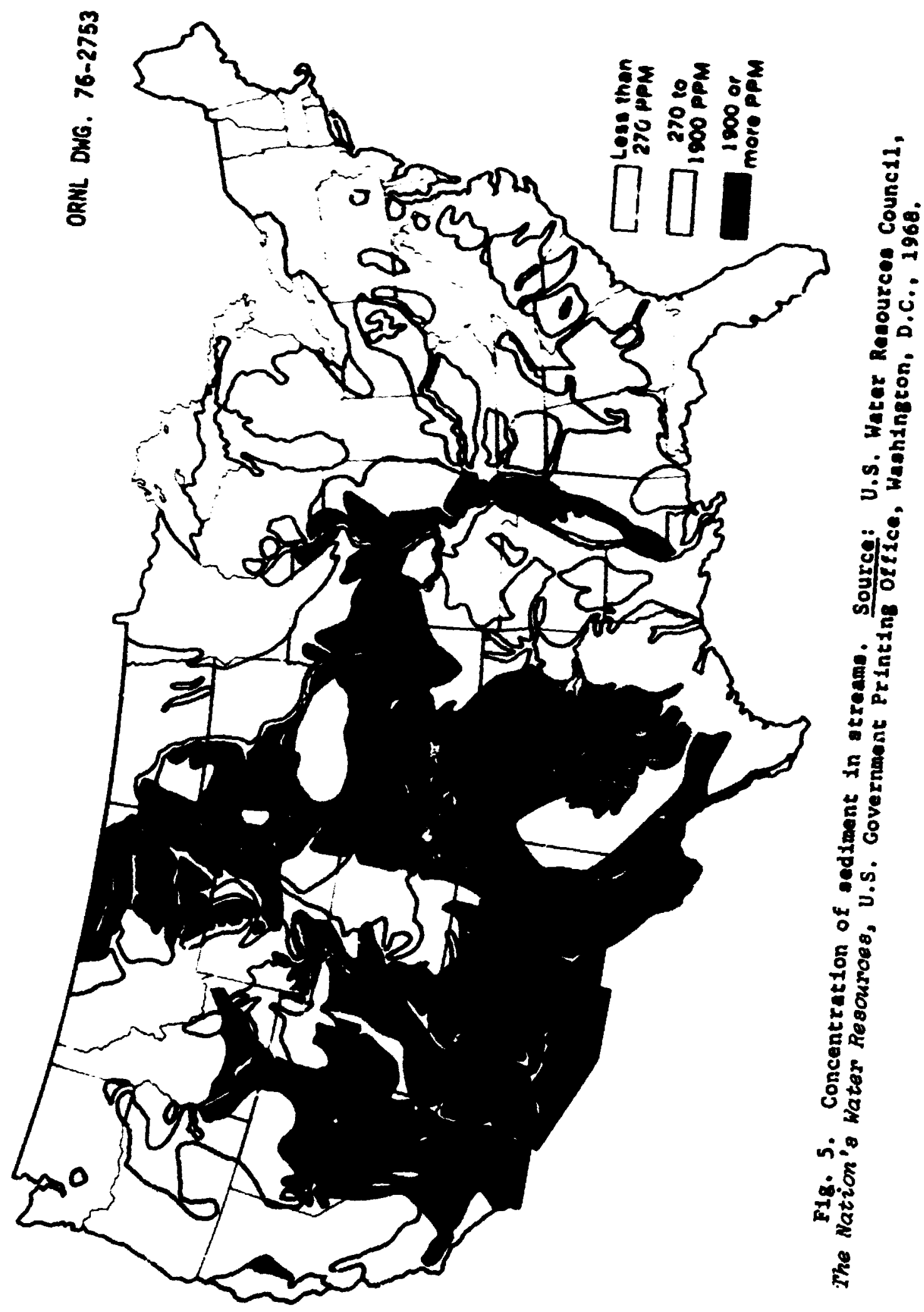




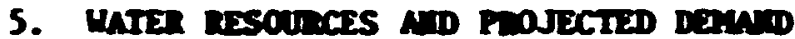

The prianty purpose of this section is to revied beckground inforation useful in derivins a set of guidelines that will enable one to deternive (1) the quantity of flow needed as a water source for an MIC; (2) whecher, and when, storage of water is required; and (3), If storage is required, the mount needed. The maners to these questions will depend on the quatity and depeadability of local water resources and the iraction of these resources that can be used for the kif.

\section{S.1 Water Resources}

To arrive at a set of guidelines, a considerable anout of background information concernins witer resources aust be understood, and the ecological, as well as other, effects of drawing on there resources must be evaluated. There is a wealth of information avallable on water resources in the Un'tted States, and a review of sone of the nore basic infornation and other considerations affecting design guidelines is given below.

As a whole, the Inited States has abundant water resources, having an annual average precipitation of $30 \mathrm{in}$. for the conterninous Intted States and an average natural runoff of 1200 billion gallons per day (equivalent to $1,860,000 \mathrm{cfs}$ ). However, these resources are not uniformly distributed, as the annual precipitation ranges from a low of about $4 \mathrm{in}$. In the Great Basin and lower Colorado regions to over 100 in. In coastal areas of the Colubia-North Pacific region (see Pig. 6). Water probles in the wre arid regions of the country are ade even more severe by high evaporation and potential evapotranspiration loses. Potential evapotranspiration is defined as the evapotranapiration that would occur if an adequate supply of water were avallable at all times and, for practical purposes, may be asouned to be nearly equal to evaporation from a free water surface as shown in Pig. $7 .^{2}$

Areas of the country in which a water surplus or deficiency comonly exists are show in Fig. 8.2 The values shown were deterndned by subtracting the pctential evapotranspiration rate frov the averace annual 


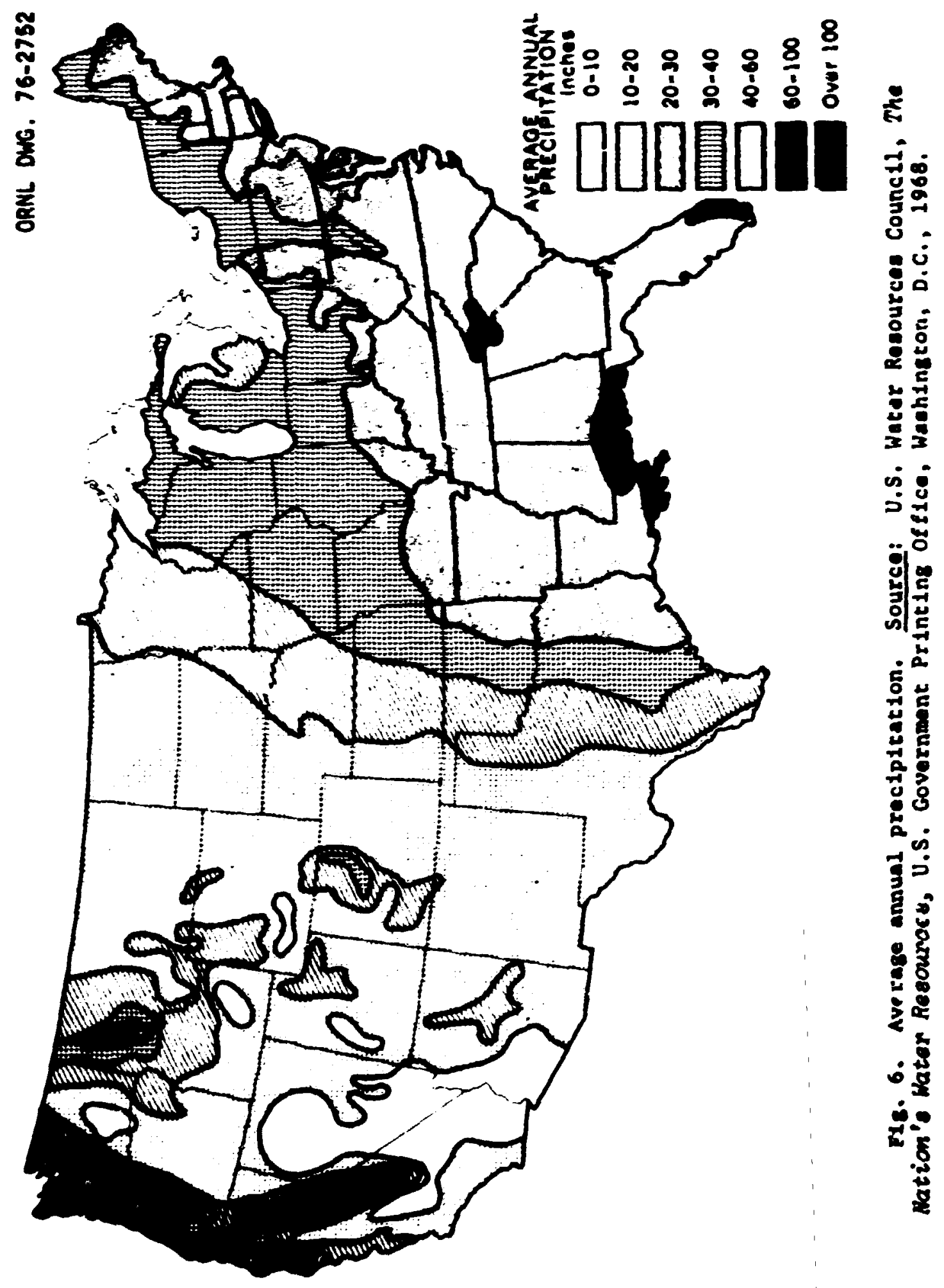




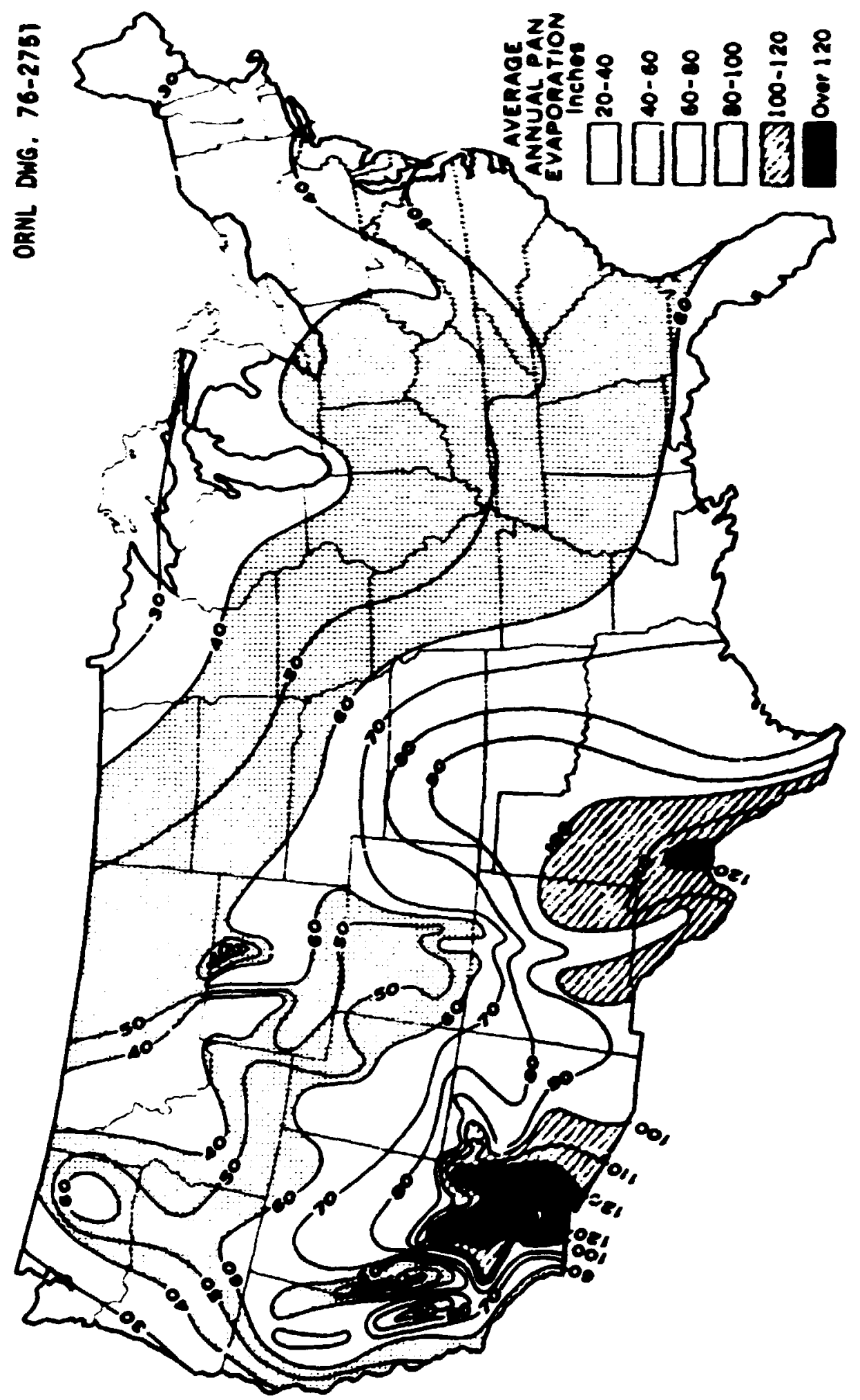

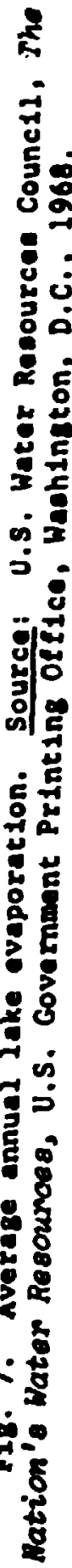




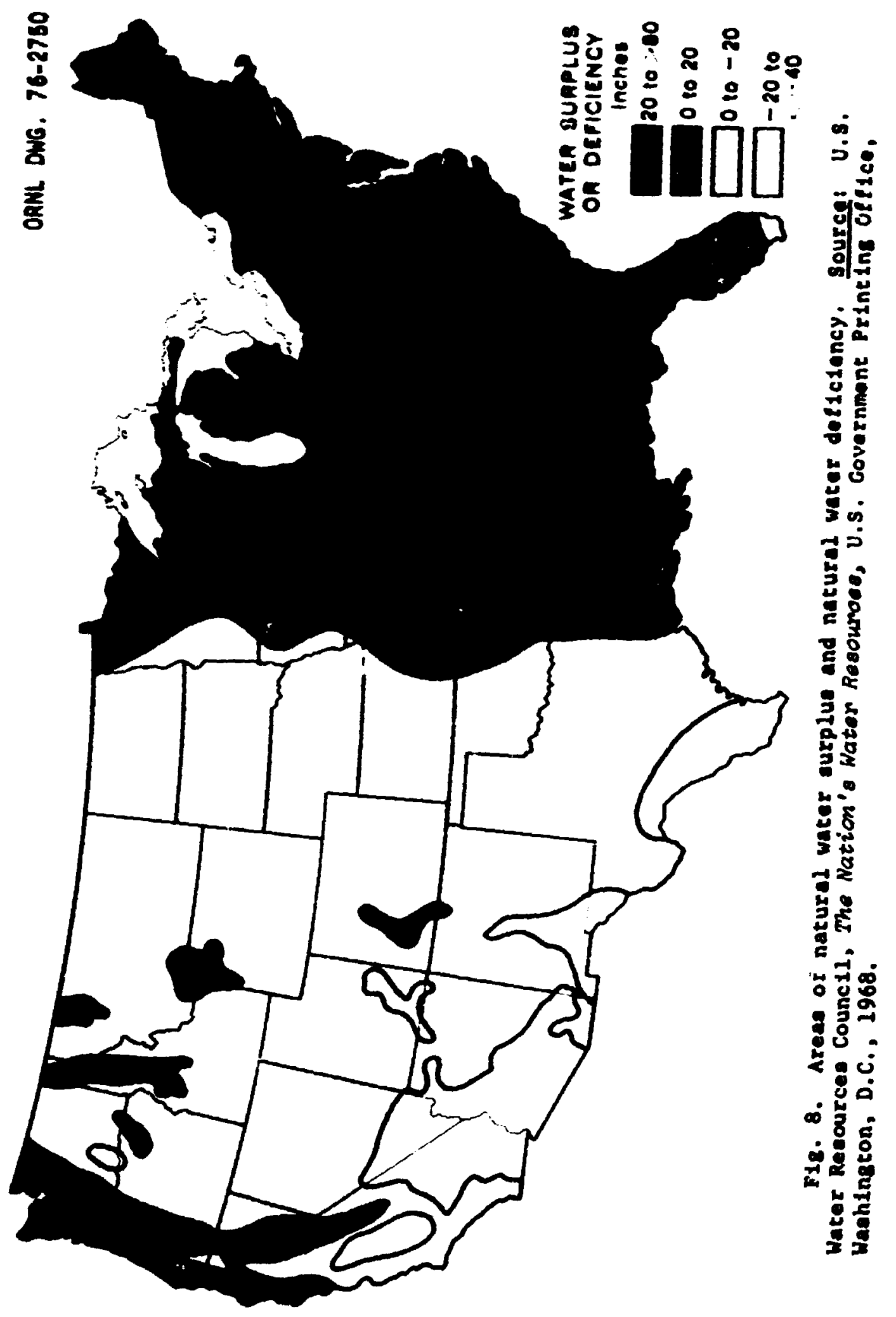


precipitation. Bowever, evea in areas mermlly uring a veter surplos, there are often seascanl or short-tere periods of deficiensy.

inland wa sites, depending on freat water for cooling, will be located wear large rivers or the Great Lakes. The avallability of weter

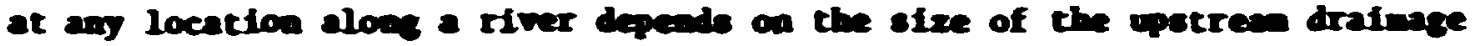
area of the river baetn, earface beter rooff for the dratmage area, and upstrem coavuptive wee or other loses. The dratinage areas of the various eajor river basios an cheir tributaries are well doctented in the U.S. Geoiogical Surves (WSCS) poblication, as are cheir surface witer runoffs (sce PIs. 9). A racher afple relation between the wean anwal flow in a river, noblecting upetrea wes and losees, and the runoff and drainge aree is as follow: The flow froe a river basto is 0.074 cfs per square ale of drainage area for eash inch of amounl rumoff. Conversely, It requitea an average rusoff of about $13.6 \mathrm{In}$. for a river to have a flow of 1 cfs per square alle of dratinge area, a value that is eypical of way rivers in the eastern balf of the Ondted States.

In addition to the wean abounl flow, the ansunl and seasosal rartattons in flou mat be considered in ang site selection proceas. The variability of amanl rinoff for the variou werer resources regions (see Fis. 10 for a eap of theae reations) is shown in F18. 11 . In the one driest vear out of 20 , the andual satural rwoff will be equal to or less then the indicated percent of the man. Seseonal flows also vary widely throughout the United States, wot oaly as to quantity, but also as to the seseon in which high and 10 flow occur. Figure 12 sbow the seasons of low flow for the United States. 5 The mubre sbown in the figure represent the woth in which the 100 flow wormlly occurs (1 for Jamuny, 2 for Pebrunty, etc.). Caution mot be exarciead in interpretIng anaual runoff or historical date on river flows because of changes that have been ande to the river bastos durias the period In which the

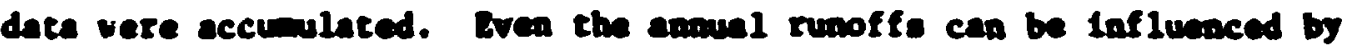
upstrese reservolrs because engy of thace hove storaye capacited greater thas helr anousl throughflow. Date and analytical techalguas are ovallable to predict flon variotions, which can be applied on a ste-by-alte basts. In considaration of the very large loveatane in an WSC, criterin 


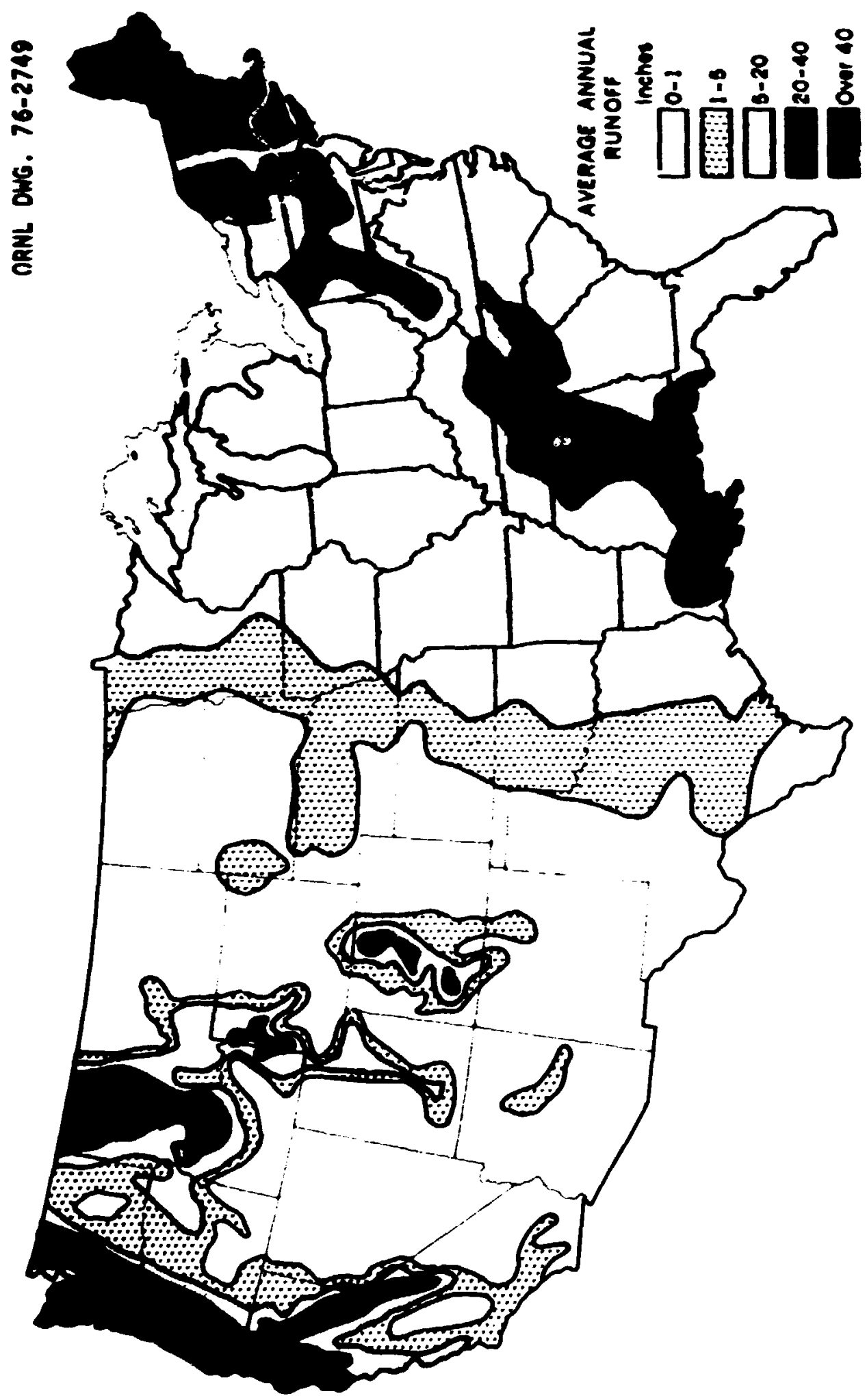

:

형

8 :

范

둥

$i^{3}$

28

붑

ํํㅇㅎㅏ

둔

4

을

돈

ㄱ.

롱

có

अ

2

- $\frac{7}{8}$

$\therefore$

in

8
0
0
3 


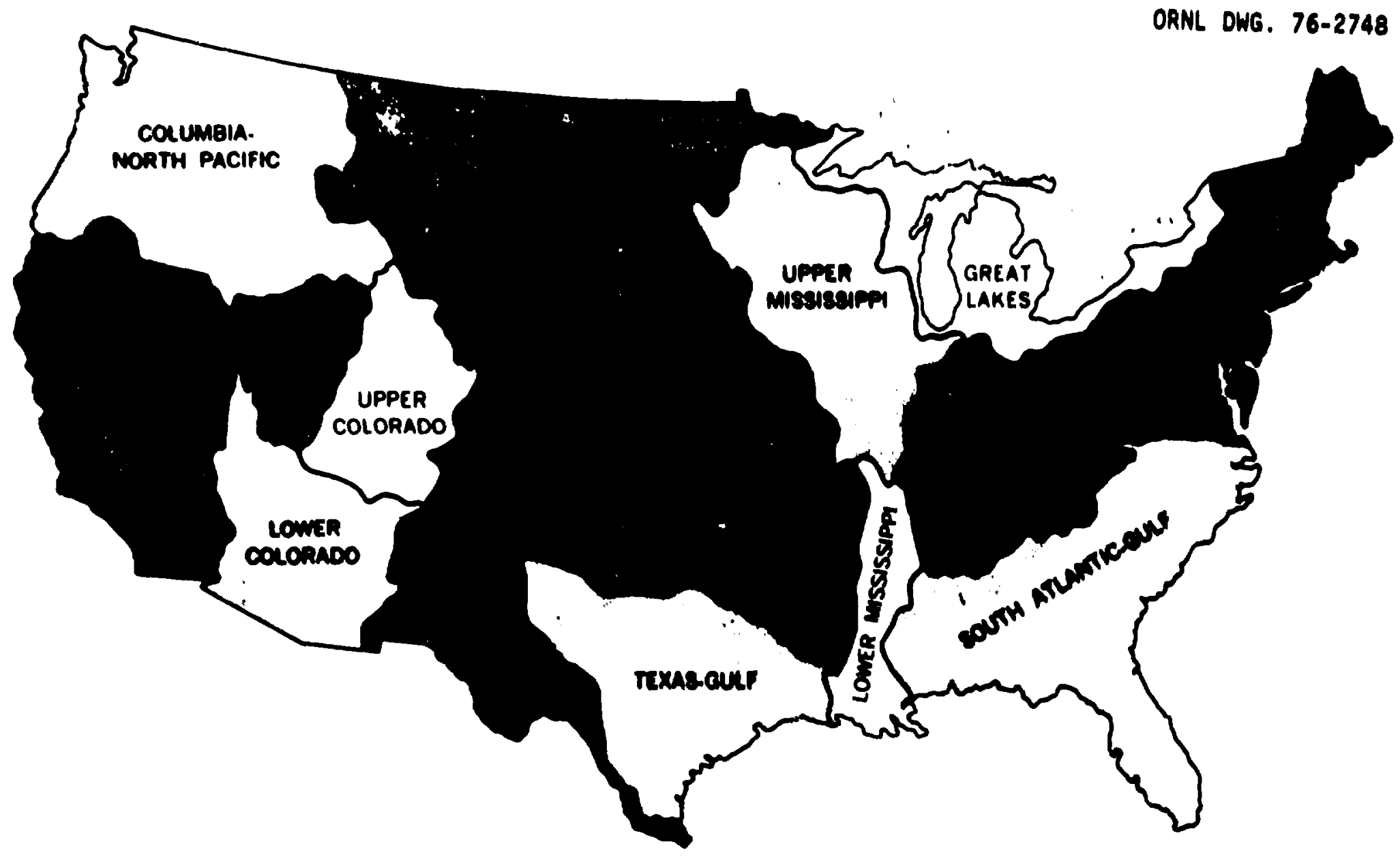

F18. 10. Water resources regione. Source: U.S. Water Resourcso counc1l, The Nation's Water Rescurces, U.S. Government Printing OCfICe, Washington, D.C., 1968. 
ORAL DNG. 76-2755

MeAN ANmUA:

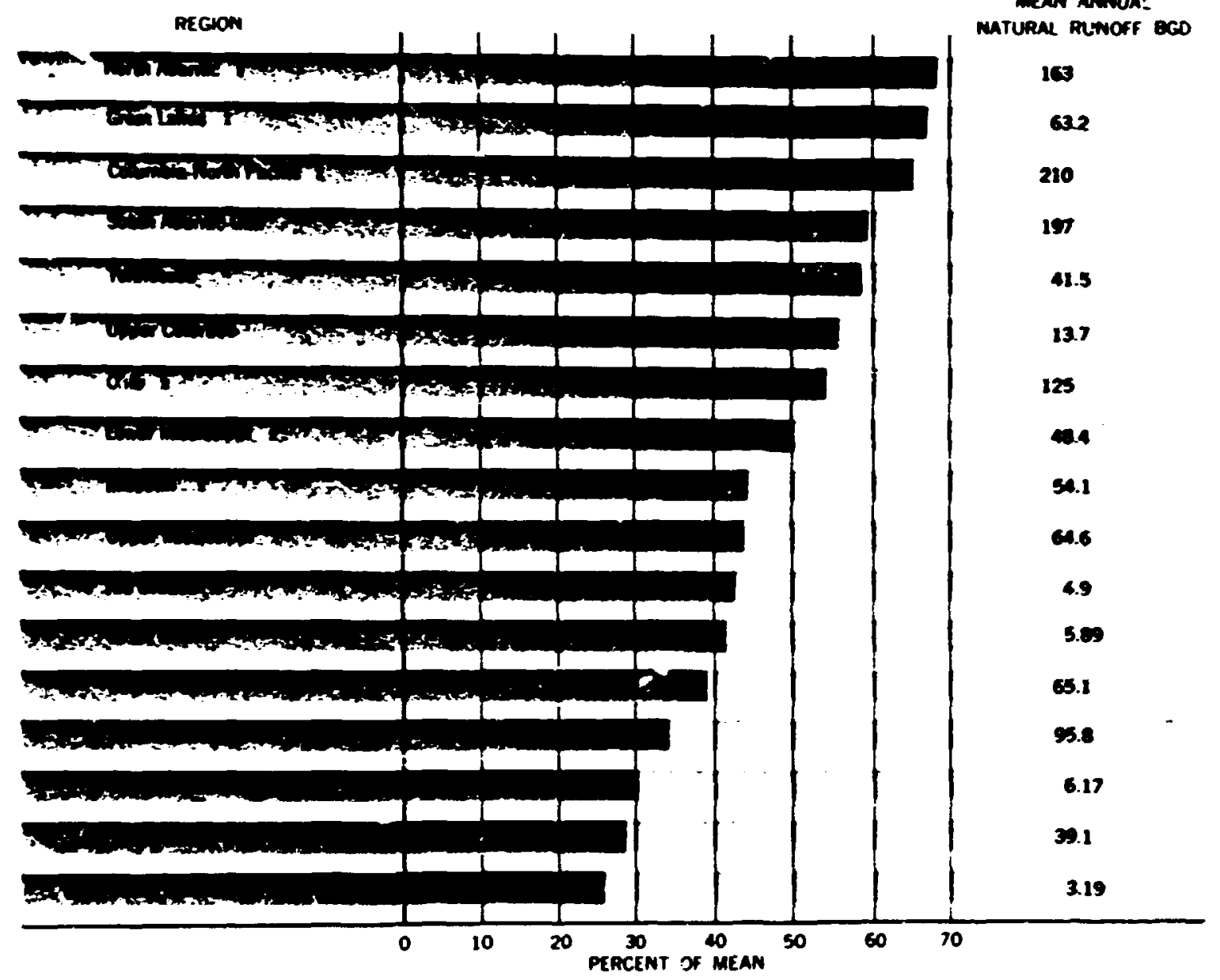

1 Does nor include runoft irom Caneda.

2 Does not melude runoff derived trom upstream regions

3 tors not include runott from Mexico

Fig. 11. Variability in annual natural runoff. In the 1 driest year out of 20 , the annuril :atural runoff will be equal to or less than the indicated pcrcent of the mean. Source: U.S. Water Resources Counc1?, The Nation's Water Rescurces, U.S. Government Printing Office, Washington, D.C., 1968. 
ORNL DWG. 76-2747

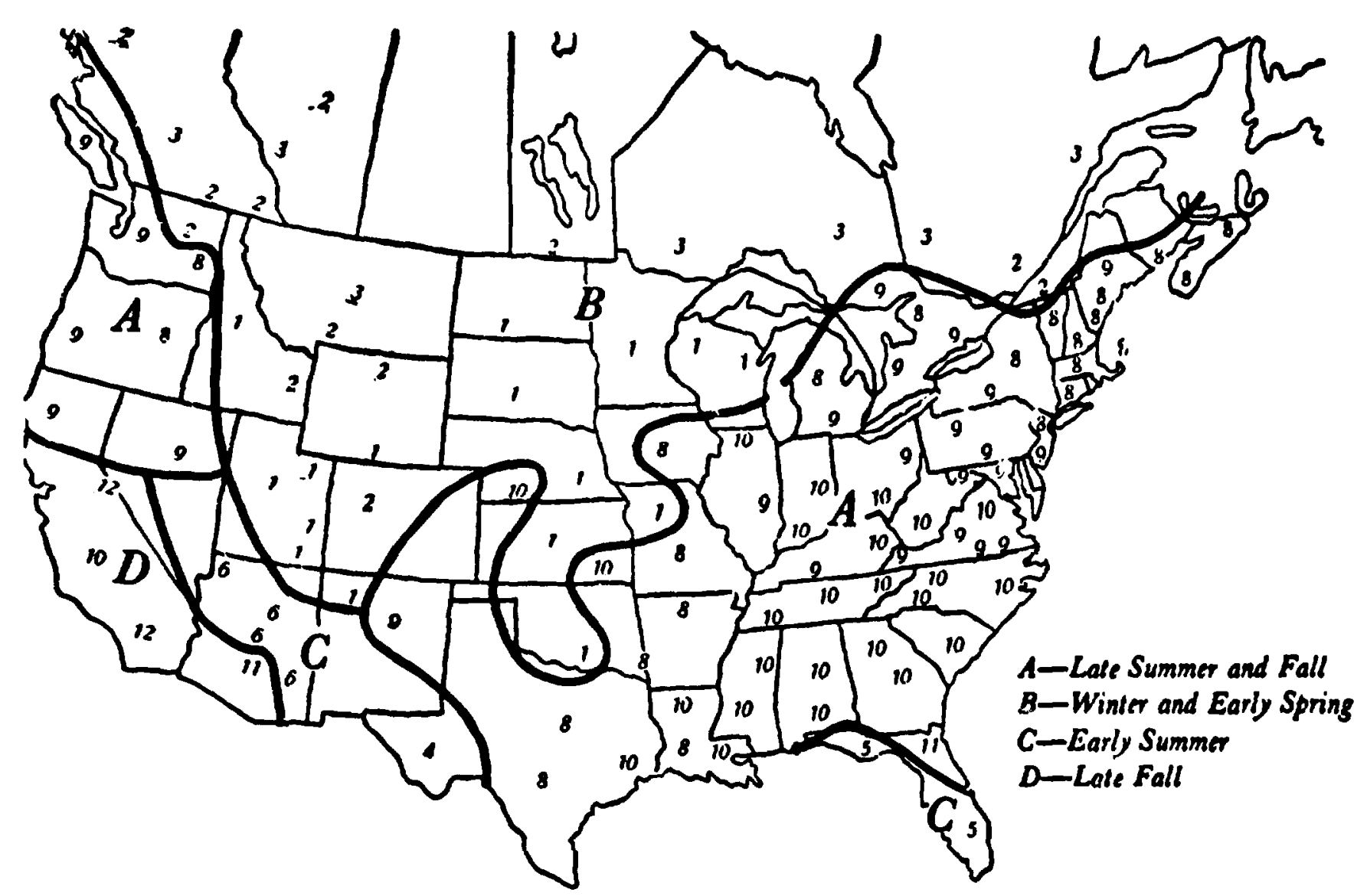

Fig. 12. Seasons of lowest flows. Source: U.S. Department of Agriculture. The Yearbook of Agriculture 1955: Nater, U.S. Government princing of $f$ ice, Washingcon, $D . c$. 
used as a basis for ident ifying potential sices should be chosen to ensure a high probability that adequate conling water supplies will be available during the center's long operating life.

\subsection{Demand Projections}

A sumary of projected withdrawals and consumptive uses of water for different purposes is given in Table 1 for the United States, and a projection of total withdrawals and consumptive uses for the various water resource regions is given in Table $2 .{ }^{2}$ These projections are based on greater efficiency of water use. Furthermore, the withdrawals estimated for year 2020 in relation to the runoff indicate a large increase in water reuse and thus a need for increased investment in water development, water cunditioning, waste treatment, and water management to meet the estimated reyuirements.

Figure 13 shows projected fresh wist: withdrawals and consumptive uses as a percent of the estimated supply. The 100 shown on each of the graphs represents the estimated average supply. The significance of these projections and precautions in interpreting the figure are taken directly from Ref. 2 and are quoted below:

In interpreting Fig. [13], attention must be given to the following points: ( 1 ) the water use figures include use of mined groundwater, which is particularly prevalent in southwestern regicns and cannot continue indefinitely, (2) the water use requirements include some saline withdrawals by self-supplied industries; (3) the water use figures do not include phreatophyte and other channel losses which are particularly important in the arid regions; (4) the water use data do not include requirements for instream uses; and (5) the data do not reflect seasnnal variations or within-region locational aspects of supply-use comparisons.

When the regional withdrawal index is 100 , the resion is withdrawing an anount of sater equal to the estimated supply (Fig. $|13|$ ). Since these withdrawals are not located at one point in the region, some parts will be reusing return flows of upstream withdrawals. The withdrawal index gives an indication of water maragement and pollution control protlems, but nut neressarily of water shortage.

The regional consumptive use index on the other hand does give an indication of water shurtage. When the existing or projected index is 50 , the region would be 
Tablo 1. Liclmated water use and projected requirements, by purpose, United States (in Mgd)

\begin{tabular}{|c|c|c|c|c|c|c|c|c|}
\hline \multirow[b]{3}{*}{ Type of use } & \multicolumn{4}{|c|}{ Withdrawals } & \multicolumn{4}{|c|}{ Consumptive use } \\
\hline & \multirow{2}{*}{$\begin{array}{l}\text { Used } \\
1965\end{array}$} & \multicolumn{3}{|c|}{ Projected requirements } & \multirow{2}{*}{$\begin{array}{l}\text { Used } \\
1965\end{array}$} & \multicolumn{3}{|c|}{ Projected requirements } \\
\hline & & 1980 & 2000 & 2020 & & 1980 & 2000 & 2020 \\
\hline Rural domestic & 2,351 & 2,474 & 2,852 & 3,334 & 1.636 & 1,792 & 2,102 & 2,481 \\
\hline $\begin{array}{l}\text { Munioipal (publ } \\
\text { supplied) }\end{array}$ & 23,745 & 33,596 & 50,724 & 74,256 & 5,244 & 10,581 & 16,478 & 24,643 \\
\hline $\begin{array}{l}\text { Industrial (self } \\
\text { supplied) }\end{array}$ & 46,405 & 75,026 & 127,365 & 210,767 & 3,764 & 6,126 & 10.011 & 15.619 \\
\hline \multicolumn{9}{|c|}{ Steam-electric power } \\
\hline Fresh & 62,738 & 133,963 & 259,208 & 410,553 & 659 & 1,685 & 4,552 & 8,002 \\
\hline Sial ìte: & 21.800 & 59,340 & 211,240 & 503,540 & 157 & 498 & 2,022 & 5,183 \\
\hline \multicolumn{9}{|l|}{ Agriculture } \\
\hline Irrigat ton & 110,852 & 135,852 & 149,824 & 160,978 & 64,696 & 81,559 & 89,964 & 96,919 \\
\hline I. ivestuck & 1,726 & 2,375 & 3,397 & 4,660 & $1,62.6$ & 2,177 & 3,077 & 4,238 \\
\hline Trtal & 269,617 & 442,626 & 804,610 & $1,368,088$ & 77.782 & 104,418 & 128,206 & 137,085 \\
\hline
\end{tabular}

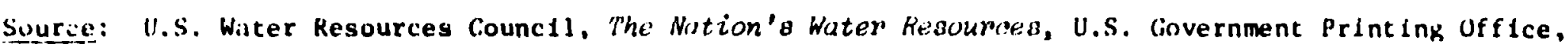
Wilshington, D.C., 1968. 
Tuble 2. Ristimated water use and projectod requirements, by reglons, Unitod states (in Mgd)

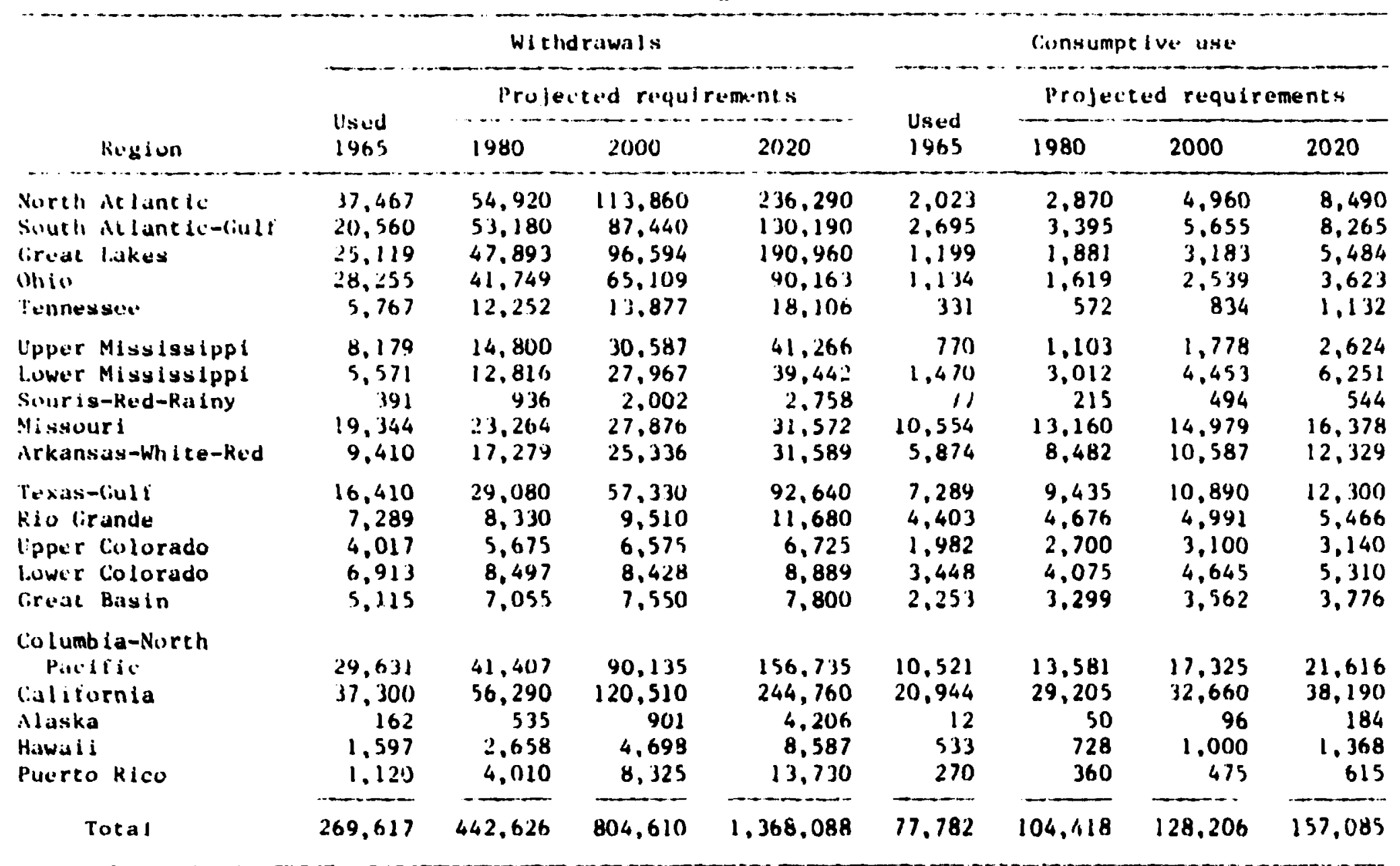

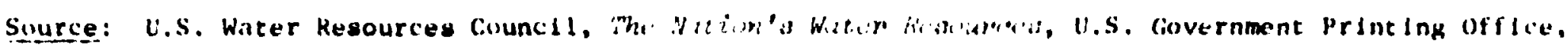
Wishingtun. D.c., 1968. 


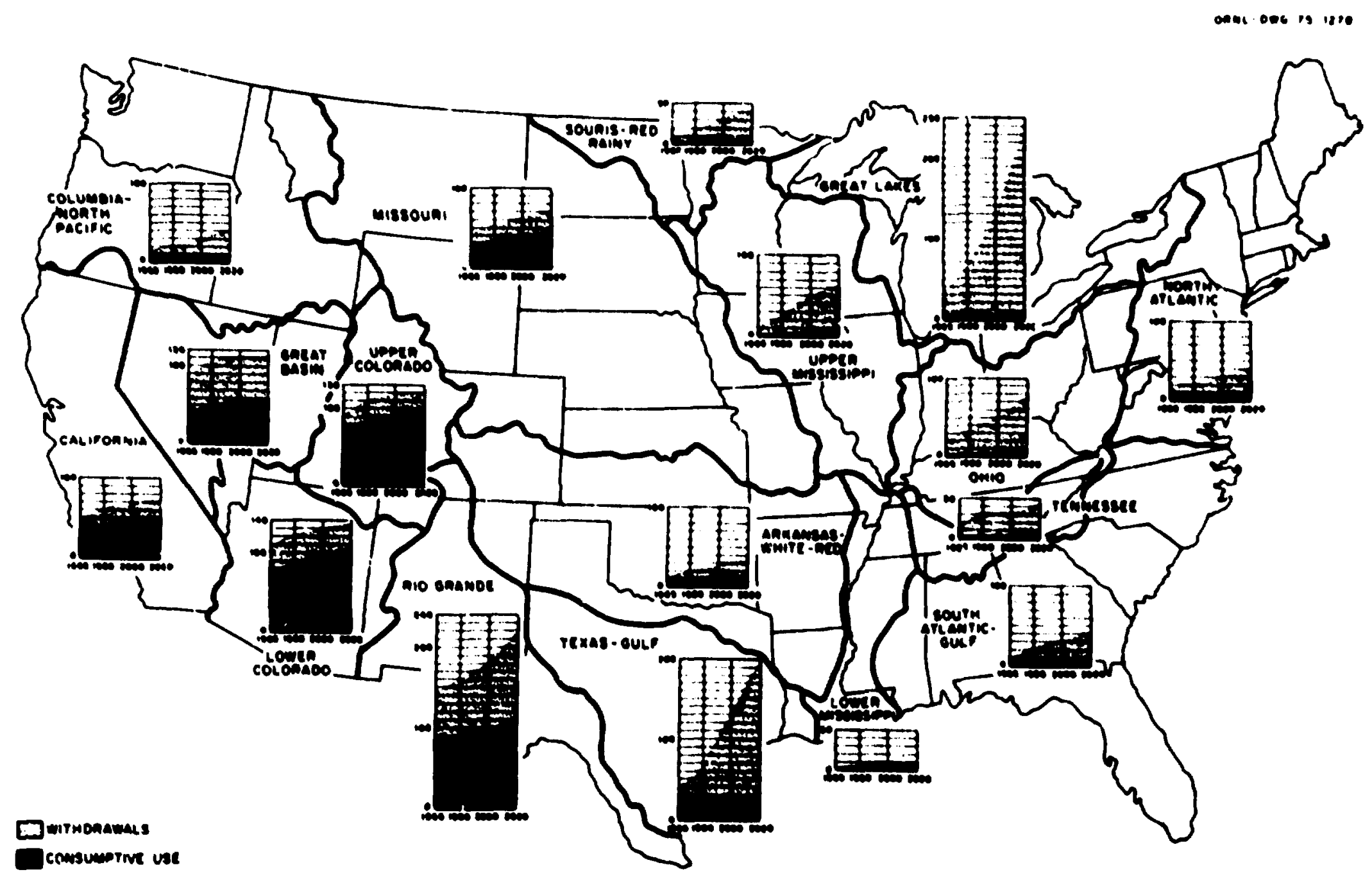

Fig. 13. Peglont 1 indices of projected water withdrawals and conauptive unes, 1965-2020 (estimaced average su iply equals 100). Source: U.S. Water Resourcen Councll, Tha' Hation'a Water Kr:surven, U.S. Government Print ing Office, Washington. D.C., 1968. 
consuning $50 \%$ of the available supply. The consupptive use Index understates the water shortage problea because account has not been taken of seasonal shortages. Also, the reglonal indices are based on averages for large regions and cover up the seriousness of water-shortage problems in local areas.

There are wany local areas in all parts of the country where shortage of water restrains economic activiny, but these areas cannot be ident if ied with the general approaches used in this analysis. Even with this linited analysis, however, the Council has identiffed several regions in which existing water resources are now inadequace or over the next 50 years will not sustain the patterns and rates of growth experienced in recent years and projected over the next 50 . The effect of water shortages, ur less counter masures are taken, will be an adjustment in the pattern of economic acti?lties. In some cases it may mean a slowdown in the rat: of increase in total economic activity in the region. In view of the present and projected inadequacy over the next 50 years of the water supplies available to met requirements in several regions, the Council finds that alternative means of alleviating such water shortages and the national interest therein should be identified and considered. Any study of surh alternative should include consideration of transfer of water between basins, interstate and international terms and conditions of such possible transfers, protection of areas of origin, econosic alternatives avallable to the areas of need, and the national interest in both areas of origin and need.

In a later study" of water resources and their relationship to energy self-sufficiency, the Water Resources Council (WRC) identified several areas of the country that may have critical water-related problems in 1985. These areas are shown in Fig. 14. There appears to be some question as to the rate of growth in energy-related water requitements used in this study; however, these growth projections primarily affect the tining of the shortages (i.e., a critical supply in 1985 or in 2000) rasher than the basic conclusions. A sumary of the problems associated with the critical areas is quoted from Ref. $h$ in the following two paragraphs:

The most severe water supply probler in the Fastern ritical regions is assocfated with fresh water consumptive use for cooling of electric power generation facilities, related thermal and refinery pollution problems and the incompatibility of develupment wi:h the desire for return 



\begin{abstract}
to or mainteaance of a natural envirunaent beld by a large rucal segant of the population. The solution to this problew lies in giving proper atceacion to environmental and social concerns as well as utilizing, wherever possible. sal ine off shore waters for cooling purposes.

The most severe water supply probles in the Hestern regions is assoclaced with fresh water consuptive use and salinicy problese for mining and processing of the oil shales and coal reserves currently plenand to be exploticed. The cost significant constraint related to this protlem is of an instituctonal nature (water rights) and wust be resulved before significant increases in consuptive use for eargy development can be accomodated. The solution to this problem is very complex and will require major State/federa] actions which are mutually acceptable to both parties.
\end{abstract}

Wollman and Bonea, ${ }^{4}$ in their honk the irat louk gr ator, present a detailed study of water supply and requirements; they profect future water dewind on the basis of mintaining adequate water quality (a minimum of 498 of dissolved oxygen per liter). Their approacin, basing the required flow on that necessary for the dilution of industrial and municipal wastes, gives a detailed economic analysis which considers the cost of both waste treatment and the reservoirs for augmenting low stream flows. The study emphasizes the need for large expenditures for waste treatment facilities to reduce waste loads and for reservoirs to improve stream flow regulation. This is illustrated in Table 3, which shows the 1964 and maximum attainable flow and projections of demands by region through 2020. The denands are based on medium projections of population and economic activity and their "minimum flow" case, which assumes a $97.5 \%$ biochemical oxygen demand removal from both industrial and municipal wastes (tertiary treatment). Both regulated flow conditions are based on a reliability of $98 \%$. The $98 \%$ reliability is defined as the probability of the flow shown being available (at al). times during the year) for all but 2 years in each 100 years. The maximum regulated flow is defined as the maximum flow that can be attained with reservoirs regardless of cost, that is, no restriction or the cost of the added flow.

In Table 3, the required flows that exceed the present regulated flow for a specific region are shown in parentheses, and the required 
Table 3. Present and aximan regulated flow and total required flow (In Mad)

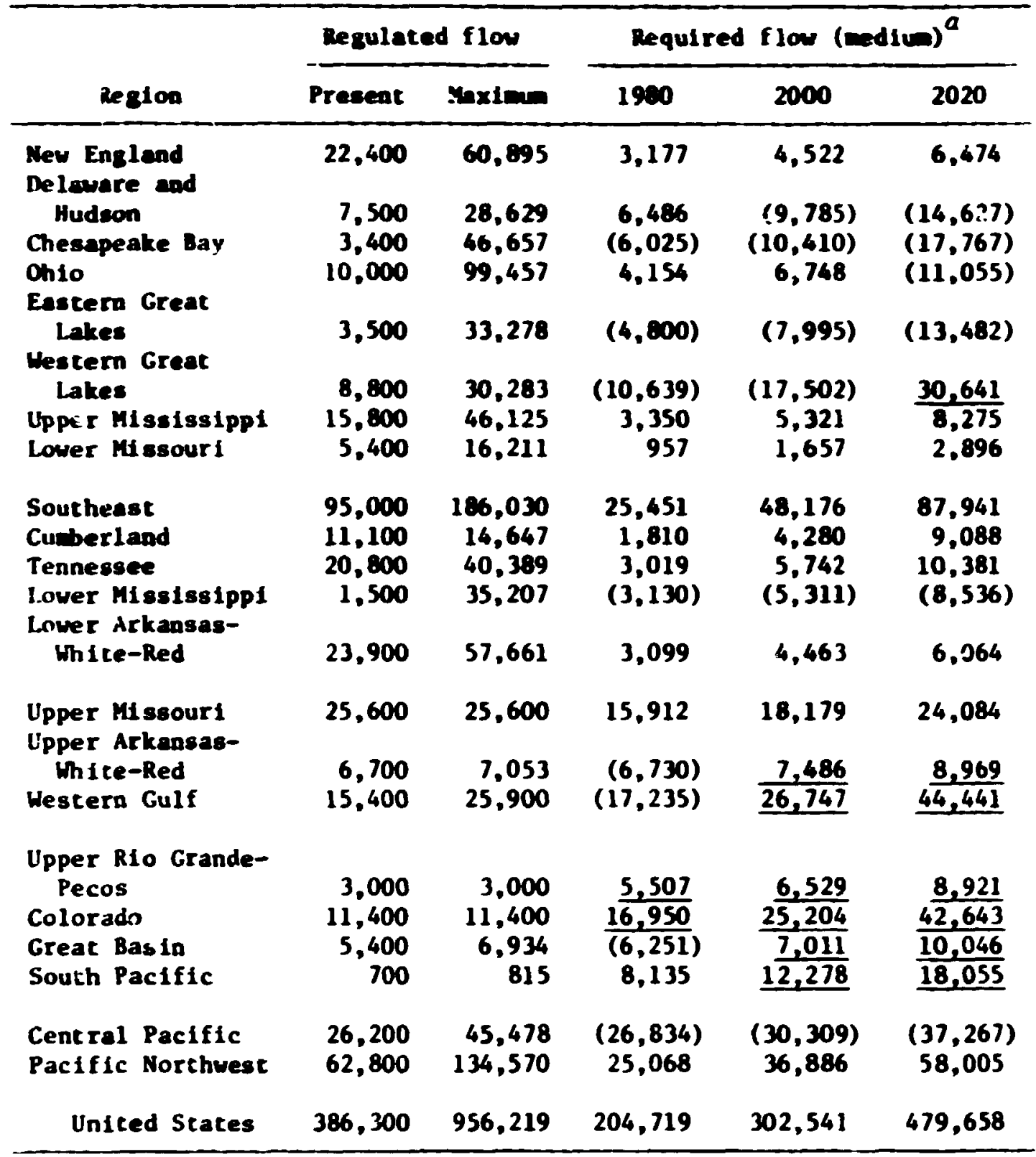

$a_{\text {Parentheses indicate projected requirements exceed present }}$ regulated flows; underlining indicates projected requi rements exceed maximum regulated flows. 
flows that exceed the maxim regulated flow are underlined. The total present and aximm potentiai regulated flows for the United States are 386 and 956 billion gallons per day (bgd). The Hater Resources Council (HRC) ${ }^{6}$ gives values for currenc and potential surface supply, with a 987 confideace, of about 300 and 800 bgd. The whC current supply of 300 bgd Is based on the sesuption that only $50 z$ of the current reservoir capacity is used to ilprove low flow conditions; whether or not restrictions were placed on the potential supply is wit stated. Considering that the average rumoff fron the United States is about $1200 \mathrm{bgd}$ and that the low runoff in one year out of 20 is about 700 bgd, a flow of either 800 or 956 bgd, with a confidence level of 987 , will requite an enormous reservoir systen, wost of which must be built.

The difficulty of maintaining a dissolved oxygen level of $4 \mathrm{~m}$ !liter is further emphasized by consideration of the EPA-proposed criteria for water quality. ' The section of the EPA report for dissolved oxygen states:

(1) Minimum acceptable lint ts of dissolved oxygen for all water shall be based upon seasonal temperatures. Minimu acceptable linits are presented in the table below:

\begin{tabular}{lccc} 
Oxyger levels & $\begin{array}{c}\text { Minimal levels } \\
\text { for protection } \\
\text { of salmonid } \\
\text { spawning } \\
\text { saturation } \\
\text { (mg/1iter) }\end{array}$ & $\begin{array}{c}\text { Minimal levels } \\
\text { for protection } \\
\text { of aquatic 1ife } \\
\text { (mg/liter) }\end{array}$ \\
\hline 36 & 7 & 6.4 & 5.8 \\
27.5 & 8 & 7.1 & 5.8 \\
21 & 9 & 7.7 & 6.2 \\
16 & 10 & 8.2 & 6.5 \\
7.7 & 12 & 8.9 & 6.8 \\
1.5 & 14 & 9.3 & 6.8 \\
\hline
\end{tabular}

(2) As an exception, under extreme conditions for short periods of not more than 24 hours, a minimum limit of $4 \mathrm{mg} / 1$ is acceptable for waters above $31^{\circ} \mathrm{C}\left(87.8^{\circ} \mathrm{F}\right)$. 
It is not the inteat of this report to diecuses national or indwetrial priorifles for water uee. Howner, the value of water for power plant cooling purposes is high if che alterastive is the use of dry cooling towers. A coeparison of puwer generatias costs (derived from Ref. 8) shows the porer coet for a plant uith dry tomers to be 1.63 -11ls/klinr greacer than for a plant with wet towers. For a 1200-iwe plant. this is about $\$ 2000 / h r$. The conouptive wee of water for the plant is between 2.0 and 2.5 acre-ft/hr. Thus, the value of water for this comparison is about $\$ 900$ to $\$ 1000 / a c r e-1 t$ and is far greater than the value of water for irrigation of field crops. 


\section{RESERVOIR CONSIDERATIONS}

For those NEC sites that require storage of water for perfods when the flow avallable from adjacent sources is Insufficient, losses (evaporation and percolation) from the reservolr must be considered. Especially, evaporation and percolation losses will increase the deand on local water resources in arid regions, where evapotranspiration losses are norally low. In sizing the reservolr, the net loss (or gain), which is the difference between the evaporation (Fig. 7) and percolation loss and the local prectpitation (Fig. 6), should be used. However, the evaporation rate will be highest during the sumer or early fall when the reservoir is probably most needed.

The reservoir capacity required will depend on the individual river flow characteristics, water demand, and reservoir losses and must be evaluated for each specific site. For most locations, a useful storage capacity equal to the plant withdraval rate during 90 to 120 days of operation should be sufficient for seasonal variations. Bu using the sumer consumption rate of $30 \mathrm{cfs} / 1200$-Me plant, a concentration ratio

of 3, and a storage capacity equivalent to 100 days of full power operation, the capacity required per plant is $3.9 \times 10^{2} \mathrm{ft}^{3}$, or about 9000 acre-ft. Although reservoir losses are neglected, the assumptions of the maximum water consumption rate and all units operating at full power should more than compensate for these losses.

There are many existing reservoirs having sufficiently large through-flows to be attractive for NEC sites. Many of these serve many purposes such as production of hydtuilectric power; thus, there may be some concern abou' the loss of power output caused by the use of water by an NEC. This can he put in perspective by noting that an NEC will produce 40,000 kHe for each 1 cfs of water evaporated, as compared with about $7 \mathrm{kWe}$ for the same amount of water dropping $100 \mathrm{ft}$ througt. a hydroturbine. 


\section{ECOLOGY COUSIDERATIONS}

The impact of the NEC water consuption and blowdown on the ecology of a lake or river basin must be considered in establishing the anount (or fraction) of water that can be consured. The ecologist is most concerned about strean flow during periods $c$ f very low flow and during the spring runoff (freshet); for example, withdrawals and imoundant of the freshet may upset flood-triggered events such as breeding cycles. Regulation of rivers and the ultimate impact of this regulation on the river ecology is a complex problen. Results of Hollman and Bonea indicate that the maintenance of oxygen levels of $4 \mathrm{mg} / \mathrm{liter}$ in rivers in most parts of the country will require an extensive reservoir system. Thus one is faced with the question of whetner it is better to impound the freshet to augaent low flow conditions to dilute wastes or to pass the freshet through the reservoir and have lower flows and probably lower quality during periods of low runoff. As vill be noted in the next section, this question has little effect on either the river flow rates or the size of reservoirs required for an NEC.

Periods of very low flow will be the mosi difticult from an ecological viewpoint. The $90 \%$ duration flow (the flow equaled or exceeded $90 \%$ of the time) has been used as a low-flow criteria by fishery biologists in anadromous $f$ ish restoration because this flow is considered adequate co ensure a stream's usability for spawning. This flow critcria is probably conservative in that the $90 \%$ duration flow is about twice the 7-day, 10-year low low for unregulated rivers.

other factors that may limit the withdrawal rate from a river are (1) as the withdrawal rate is increased, the amount of life in the river that is drawn into and destroyed within the plant cunling system is increased. and (2) the consumption of water from lower river basins that ieed estuaries must he evaluated from the standpoint of the effect on the estuary and the upstream movement of the salt front. The general importance of esturies to the marine life cycle may severely iestrict their use as either a water source or a point of rischarge for blowdown. 


\section{RIVER FLOW REQUIREMENTS}

The water resources required for an NEC will depend primarily on what fraction of the water can be consumed and whether storage (either existing or added) is used. The most important consideration is the availatility and dependability of an adequate amount of water. As noted previously, the peak water consurption rate for each 1200-Mile unit is about $30 \mathrm{cfs}$, and this rate progresses arithmetically as the number of NEC units increases. The local water resources must be sufficient to reliably sipply this q.entity without serious impact on the area. Another significant factor cuncerns water quality (e.g., impurities and temperature) and its effect on requirements for water treatment and management of cooling tower blowdown.

There are some arid regions in western areas of ihe country with acute or impending water shortage problems where river flow criteria have no aning because of the heavy water withdrawals already being practiced. These rivers, such as the Colorado, upper Snake, and Sacramento, must be evaluated on an individual basis, and, in general, any si;nificant use of water from these rivers will require further basin development, purchase cf water rights, or reallocation of these resources.

Although each site must eventually be judged on the basis of local considerations, the following general criteria will be used for screening purposes to identify areas that appear to have suf ${ }^{c}$ icient water to support an NEC. Kestrictions affecting reactor steing or iocal insttutionjl reitraints on the use of water are not considered.

\subsection{Criter :a for River Flow Without Storage}

The criteria used to evaluate the adequacy of a river to support an NEC, without storage, will consist of two factors. The first is that the maximum consumptive use w111 be no greater than $10 \%$ of either the 7-day, 10-year or che monthly, 20-year low flow. For mariy rivers, the l bus for threse two condtions are about the same. The second condicton is that the withdrawal rate will be no greater than $15 \%$ of the 7 -day, 
10-year or monthly, 20-year low flow. These two conditions will be equally restrictive for a concentration ratio of 3 . For concentration ratios less than 3 the withdraval restriction will be liniting, and for ratios greater than 3 the consuptive use restriction will be liniting. These criteria will be based on projected flows for the rivers considering their current state of regulation and will be applied to both regulated and unregulated river systens.

These criteria can also be applied, with modifications to include plant factors, to the cunulative effects of several energy cencers distributed along a major river systes. (This is discussed in detall later.) Even for a single energy center, as the number of plants increases, the probability of having all plants in operation at the same time decreases. Thus the value used for water consurption and withdrawal rates becones nore conservative as the nuber of plants increases.

The ecological ilpact of these criteria can be evaluated by using approximations for unregulated rivers. The $90 z$ duration flow, which corresponds to about 202 of the mean annual flow, has been used by fishery biologists in anadromos fish restoration prograne as adequate to ensure a strean's usability by anadrowous fish for spawing. For unregulated rivers, the 7-day, 10-year low flow 18 about half of the $90 z$ duration flow, or 108 of the mean annual flow. A consuption rate of $10 \%$ of the 7-day, 10-year low flow inplies that there will be a $5 z$ reduction in the $90 z$ duration flow. Because the accuracy of river flow measurements is about 57, the inpact of this consuption rate should be small. Furthernore, most river basins with sufficient flow to support an NEC will be at least partially developed with flow augentation during months of animan flow, It is probable that the 7-day, 10-year low flow on these regulated rivers; after $10 z$ consuffition by an MEC, will be greater than the $90 \%$ duration flow for the rivers in their natural state.

Restrictions on the withdrawal rate are to limit therwal discharges and the amount of aquatic life that is drawn into and destroyed within the NEC cooling system. With the withdrawal restricted to $15 \%$ of the 7-day, 10-year low flow, there would be a short period of from one to 
several days during the life of the NEC in which the withdraval rate would approach $20 z$ if the center was operated at full capacity during this low flow period.

Also, for a consumption rate of $10 z$ of river flow and a concentration ratio of 3 , the thernal discharge due to blowdown flow will increase the mean river temperature by an amount between 5 and 62 of the texperature difference between the blowdown flow and the river (see Fig. 3). This would normally linit the river temerature rise to less than $3^{\circ} \mathrm{F}$ for the most adverse conditions of ambient air and river uater temperatures. Even during those short time pertods when the river flow rate is less than the 7-day, 10-year low flow, the river temperature rise, with the above restrictions, should be within the $5^{\circ} \mathrm{F}$ linit proposed by EPA.

The percent of the wean annisal flow that way be consumed with these restrictions will vary widely, depending on the variability of seasonal runoff and the degree of stream regulation. By using approximations for unregulated eastern rivers, about 17 of the mean flow may be consumed. Two examples that show how videly this percentage way vary are the Arkansas and Tennessee Rivers. The Arkansas River at Little Rock has a mean annual flow of $39,800 \mathrm{cfs}$, but the projected monthly (October), 20-year in flow is expected to be only $2100 \mathrm{cfs} .9$ Using 102 of this $2100 \mathrm{cfs}$ restricts the consumption to $210 \mathrm{cfs}-0.537$ of the mean annual flow.

The Tennessee River is an example of a well-regulated river basin having relutively seall variations ir: annual runof $f$. The mean annual flow near Paducah, Kentucky, is 63,100 cfs and the expected monthly (September), 20-year low flow is $23,600 \mathrm{cfs} .9$ Ten percent of this low flow is $2360 \mathrm{cfs}$, which is more than sufficient to supply a 40-reactor NEC. The allowable consumption rate assumed for this case would be 3.72 of the mean annual flow, over 7 times that of the Arkansas River.

In suimary, for NECs without onsite storage, these ariteria require a minimum 7-day, 10-year or monthly, 20-year low flow of 3000 cfs for 10 reactors and $12,000 \mathrm{cfs}$ for 40 reactors. For rivers with: poor water quality, the restrictions on the concentration $r a t i o$, and thus the withdrawal rate, may impose requirements for iarger flows. However, for 
screening purposes, the 7-day, 10-year or monthly, 20-year flow of $3000 \mathrm{cfs}$ will be used to identify those areas having potential for supporting a 10-reactor conplex.

\subsection{Criteria ior River Flow with Storage}

Storage of water for use during periods of low river flu can add many potential NEC sites. In deriving a criterion for the river flow required for this case, neither the feasibility of buildiag the reservoir nor the required capacity of the reservoir will be considered because these consideratons are site-dependent and must be considered on a siteby-site basis.

Water may be stored by on-strean reservoirs or by puping to special single-purpose off-strean reservoirs for an XEC. If the water use or resource requirement considerations are liaited to water consuption and downstream ef fects, then requirements for the two systens are identscal. Off-stream storage, which requires an additional puming systen with the water withdrawal rate I inited by the river flow rate, is probably wore expensive than on-stream storage. For site screening purposes, the water use criteria for both storage systems will be assumed the same, and the following discussion will be limited to on-strean storage.

The criteria for required river flows with storage will depend on whecher the reservoir is intended for seasonal flow variations only or for both seasonal and annual variations. A rather cursory exanination of the dependable yield data for rivers, such as those shown in Tables 4,5 , and 6 for the lower part of the White, Arkansas, and Mississippi Rivers, 10 shows that storage for annual flow variations coulc be very difficult and expensive. Thus, for the purpose of this analysis, storage will be assumed tc be for seasonal variatious only, and the flow criteria will be based on low annual average flows.

The criterion assumed for deterwinting the reguired flow with storage is that the consumption rate must not exceed $10 \%$ of the annual average low flow expected for any one year out of each 20 years (annual, 20-year low flow). The Arkansas and Tenuessee Rivers are used as examples to show the extremes of the effect of this cricerton on the percentage of 
Dean annual flow and wothly, 20-year low flows that will be consumed. Although the man annual flow of the Arkansas Riwer at little Rock is $39,800 \mathrm{cfs}$, the annual, 20-year low flow is expected to be as low as $11,100 \mathrm{rfs}^{9}$ ien percent of this low annual flow is, therefore, $1100 \mathrm{cfs}$. Alchough this $1100 \mathrm{cfs}$ is only 2.782 of the mean annual flow, it is 52.97 of the expected conthly, 20-year low flow; that is, 52.92 of the noral reservoir through-f low could be consuned during this pertod. For such low flow periods, it would be necessary to draw on the reservoir to augaent dowstrean flow.

The Tennessee River, at Paducah, Rentucky, has a cean annual ilow of 63,000 cfs and an expected annul, 20-year low flow of 48,600 efs. 9 The criterion would pernit the consuption of $4860 \mathrm{cfs}$, which is $7.7 \%$ of the mean ansual $f$ low and 20.62 of the projected monthly, 20-year low flow of $23,600 \mathrm{cfs}$. These exaples again enphasize the desirability of locating NECs on controlled river systems having small variations in annual runoff.

Tabl2 4. Dependable yield, thite River at Clarendon, Arkansas, Station 7-0778, under regulated conditions

\begin{tabular}{cccc}
$\begin{array}{c}\text { Consecutive years } \\
\text { of lowest flow }\end{array}$ & $\begin{array}{c}\text { Inclusive } \\
\text { years }\end{array}$ & $\begin{array}{c}\text { Average flow } \\
\text { for inclusive } \\
\text { years (cfs) }\end{array}$ & $\begin{array}{c}\text { Percent of mean } \\
\text { for period } \\
\text { of record }\end{array}$ \\
\hline 1 & 1963 & 13,100 & 43.6 \\
2 & $1963-64$ & 15,400 & 51.3 \\
3 & $1954-56$ & 17,170 & 57.1 \\
4 & $1953-56$ & 19,480 & 64.8 \\
5 & $1963-67$ & 19,940 & 66.4 \\
$n$ & $1962-67$ & 20,990 & 69.8 \\
7 & $1959-65$ & 22,670 & 75.5 \\
8 & $1960-67$ & 23,090 & 76.8 \\
9 & $1959-67$ & 22,890 & 76.2 \\
10 & $1959-68$ & 24,230 & 80.6 \\
47 & $1924-70$ & 30,010 & 100.0 \\
\hline
\end{tabular}


Table 5. Dependable yield, Arkansas River at Little Rock, Arkansas, Station 7-2635, under unregulated conditions

\begin{tabular}{cccc}
\hline $\begin{array}{c}\text { Cunsecutive years } \\
\text { of iovest flow }\end{array}$ & $\begin{array}{c}\text { Inclusive } \\
\text { years }\end{array}$ & $\begin{array}{c}\text { Average flow } \\
\text { for foclusive } \\
\text { years (cfs; }\end{array}$ & $\begin{array}{c}\text { Percent of mean } \\
\text { for period } \\
\text { of record }\end{array}$ \\
\hline 1 & 1940 & 10,820 & 27.2 \\
2 & $1963-64$ & 16,990 & 37.6 \\
3 & $1954-56$ & 14,260 & 35.8 \\
4 & $1953-56$ & 16,920 & 42.5 \\
5 & $1963-67$ & 19,170 & 48.1 \\
6 & $1962-67$ & 23,120 & 58.1 \\
7 & $1962-68$ & 26,639 & 66.9 \\
8 & $1963-70$ & 29,160 & 73.2 \\
9 & $1962-70$ & 30,680 & 77.1 \\
10 & $1931-40$ & 30,560 & 76.8 \\
43 & $i+28-70$ & 39,820 & 100.0 \\
\hline
\end{tabular}

Table 6. Dependable yield at Station 72890.00, Mississippi River at Vicksbur8, Mississippi

\begin{tabular}{cccc}
$\begin{array}{c}\text { Consecutive years } \\
\text { of lowest flow }\end{array}$ & $\begin{array}{c}\text { Inclusive } \\
\text { years }\end{array}$ & $\begin{array}{c}\text { Average flow for } \\
\text { inclusive years } \\
\text { (1000 cfs) }\end{array}$ & $\begin{array}{c}\text { Percent of } \\
1929-1970 \\
\text { mean }\end{array}$ \\
\hline 1 & $1931-1931$ & 272 & 49.2 \\
2 & $1940-1941$ & 330 & 59.7 \\
3 & $1954-1956$ & 394 & 71.4 \\
4 & $1953-1956$ & 409 & 74.0 \\
5 & $1953-1957$ & 441 & 79.9 \\
6 & $1936-1941$ & 473 & 85.7 \\
7 & $1953-1959$ & 473 & 85.7 \\
8 & $1934-1941$ & 478 & 86.5 \\
9 & $1934-1942$ & 491 & 88.9 \\
10 & $1931-1940$ & 495 & 89.7 \\
42 & $1929-1970$ & 552 & 100.0 \\
\hline
\end{tabular}


The ilpact of this criterion on the ecology of the river and the water available for other uses is not severe. The ecologist is aost concerned about mintaining adequate flows during the spring flood (freshet) or during periods of very low flow. In analyzing the flow requiremeats for the river ecology. it is assuned that the normal low river flow would be maintained by drawing on the reservoir during periods of low flow. The amount of water stored during the freshet (if any) need have litcle or no effect on either the mount of water that way be consuned by an NEC or the storage requirements for an NEC. There are several reasons for this. First, in wost cases, the amunt of water dran fron the reservoit during low river flows will be $n 0$ greater than about 100 days of full power operation, which is less than 3: of the annual, 20-year low flow. Thus, even if no water is stored for one monch during the freshet, there is still sufficient flow available to refill the reservoit before the next low flcw season. Second, a low anmual flow sometimes results from iack of a heavy runoff during the freshet, and there is little loss in letting this flow pass through the reservoir.

The effect of an NEC on the river ecology or, conversely. the eflect of maincaining flow for river ecology on the flow available for an NEC can be shown by Fig. 15. This figure shows an assumed set of river flow conditions, plant water usage, and reservoir operation for a low-f low year. Although the river flow rates are assumed, the $90 \%$ duration flow (20\% of the mean andual flow) and the low flow (10z of the mean annual fluw) are typical of many U.S. rivers. Also, the annual lor flow used in Fig. Is (1/2 of the mean annual flow) is typical of the innual, 20-jear low flow of many li.s. rivers.

The assused conditions for Fig. 15 are a river wea, annual flow of $6000 \mathrm{cfs}$, a $90 \%$ duration flow of $1200 \mathrm{cfs}$, a plant withdrawal rate of $450 \mathrm{cfs}$, and a plant consumption rate of $300 \mathrm{cfs}$ (a 10-reactor energy center using $10 \%$ of the annual, 20-year low flow). The reservoir is assumed to be full at the end of March, and piant withdrawal requitements are to be net by using the reservuir during the freshet (April) or when withdrawal from the river would reduce the river flow below 1200 ifs. The reservir is not used to augment low river flows when the flow drops 

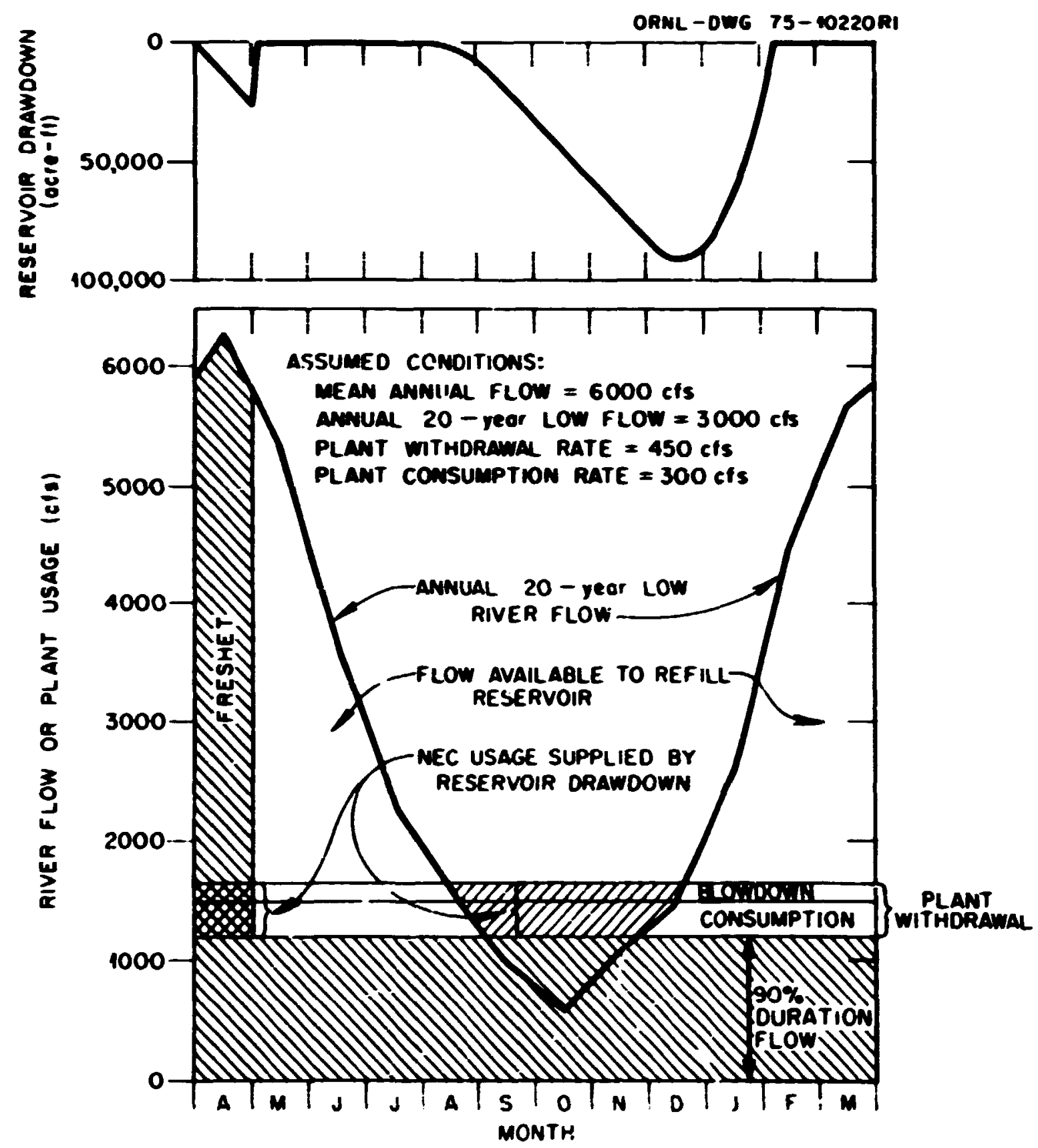

Fig. 15. River flow rates, plant water usage, and reservolr operation for a 10-reactor NEC. 
below the 1200 efs; hovever, it che plant blowdown is returned to the river during periods of low flow, this blowdown flow would add $150 \mathrm{cts}$ to the low river flow.

As show in Fig. 15, the reservoir drandown during the freshet is about 27,000 acre-ft and is rapidly refilled during early kay. The maximul demand on the reservoir will be during excended low river flow conditions. For the conditions used in this exaple, the reservoir supplies all or part of the plant withdrawal requirements for about four month, results in a drandown of about 90,000 acre-f $t$, and requires about six weeks to be refilled. The total water consuned by the plant is 103 of the cotal tiver flow during the year and about 202 of the flow not set asice for ecological considerations. Although the consumt ion rate used in this exaple was held constant near its maximm, in actual operaticn the water consuption and reservoir draudown would be less. Also, the probability of all 10 reactors operating at full power for six months is cre year is negligible. Furt:ernore, during part of the tie that tI 2 reservoir is being used, the bloudowil can probably be added to the : :ver as part of the 902 duration flow of $1200 \mathrm{cfs}$.

In an average year the river flow would be about twice that shown in Fig. 15. The water consuned would be about $5 \%$ of the coral river flow and atout 7.5\% of the flow not set aside for ecological considerations.

other factors that aust be considered from an overall water mageaent viewpoint are the effects of reservoir operation on aquatic Iffe and management of the blowdown. The percent of the cotal reservoir volume that is used should be liaited to prevent excess loss of aquatic life. This will influence the reservofr capacity but not the required river flow rate. Another factor that must be evaluated is the effect of the blowdown on the river during periods of low flow. If this becomes a serious problem, then some off-strean storage ay be needed to cool or store the blowdown unt il the reservoir's through-f low rate Increases.

In sureury, for streans having storage, a water availability retcetion requíring an annual, 20-year low flow of 3000 cfs for 10 reactor: and $12,000 \mathrm{cfs}$ for 40 reactors dppears reasonable for initially srreening areas as potential NEC sites. 


\section{RIVER FLOU RATES}

Maps of the United States (48 contiguous states) showing those rivers with sufficient flow to be of incerest for varions sises of reactor complezes are shown in Figs. 16, 17, and 18. Ftoure 16 shows chose rivers hevine wean anual flows greater than $3000 \mathrm{cfs}$. The river flow rates are also identified by ranges -3000 to 6000,6000 to 12,000 , 12,000 to 24,000 , and greater then 24,000 cfs. Although the cean anounal flow is the wost comonly reported value for river flow rates, it does not give any indication of the vide variability in the ancal and seasoual runoff or their effects on flor rates. However, it does represent the maxim low flow potential of a completely developed river basin.

Figure 17 shows those rivers with an anval, 20-jear low flou that is greater chas $1500 \mathrm{cfs}$. The river flows are acain identified by ranges, and for this case the ranges are 1500 to 3000 , 3000 to 6000 , 6000 to 12,000 , and greater than 12,000 cfs. An discussed in Sect. 8.2, the ammual, 20-year low flow is the flow criterion proposed for rivers with storage. By using this criterion for storage and a weter consuption race of $30 \mathrm{cfs} / 1200$-nile reactor (a required annual, 20-jear flow rate of $300 \mathrm{cfs} / 1200$-ille reactor), the four flow ranges shown in Fis. $17 \mathrm{can}$ support power generation conplezes of 5 to 10,10 to 20,20 to 40 , and greater than 40 reactors.

Figure 18 shows those rivers with woathly, 20-year low flows greater than 1500 cfs with the flow rates again ideatified by ranges of 1500 to 3000,3000 to 6000,6000 to 12,000 , and greater than 12,000 cfs. The conthly, 20-year low flow is the criterion proposed for the case of no storage, and the flow ranges represent rates sufficient to support 5 to 10,10 to 20,20 to 40 , and greater than 40 reactors without storage.

The purpose of these axp is to identify water resources and not to reflect restrictions that affect reactor sicins or other needs or restrictions that affect water availability in the various regions. For exmple, both the Colorado and Sacranato Rivers are show as being capable of supportins nuclear eargy centers. However, diversion of water from the lower part of the rivers is such that the outflow from 


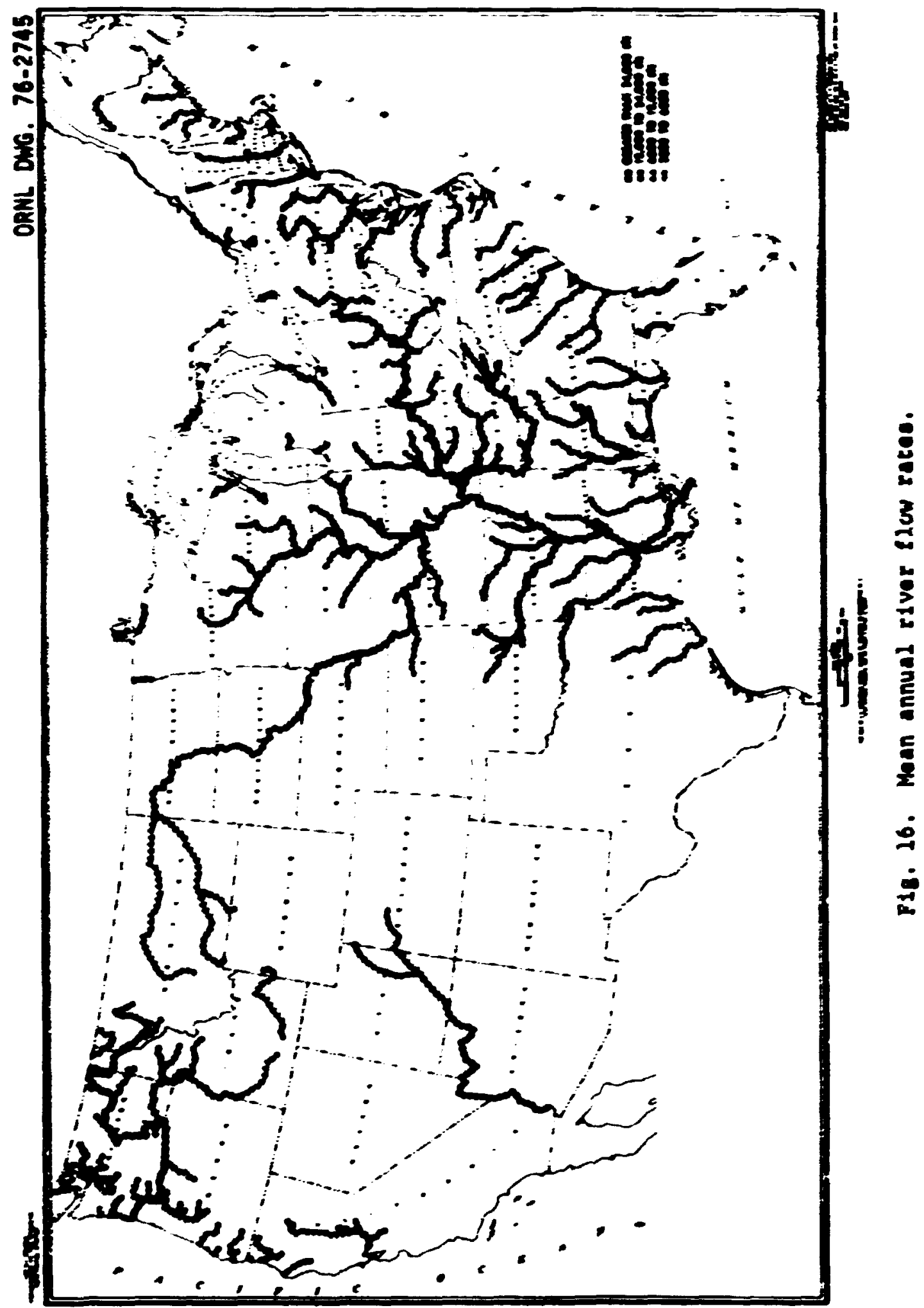




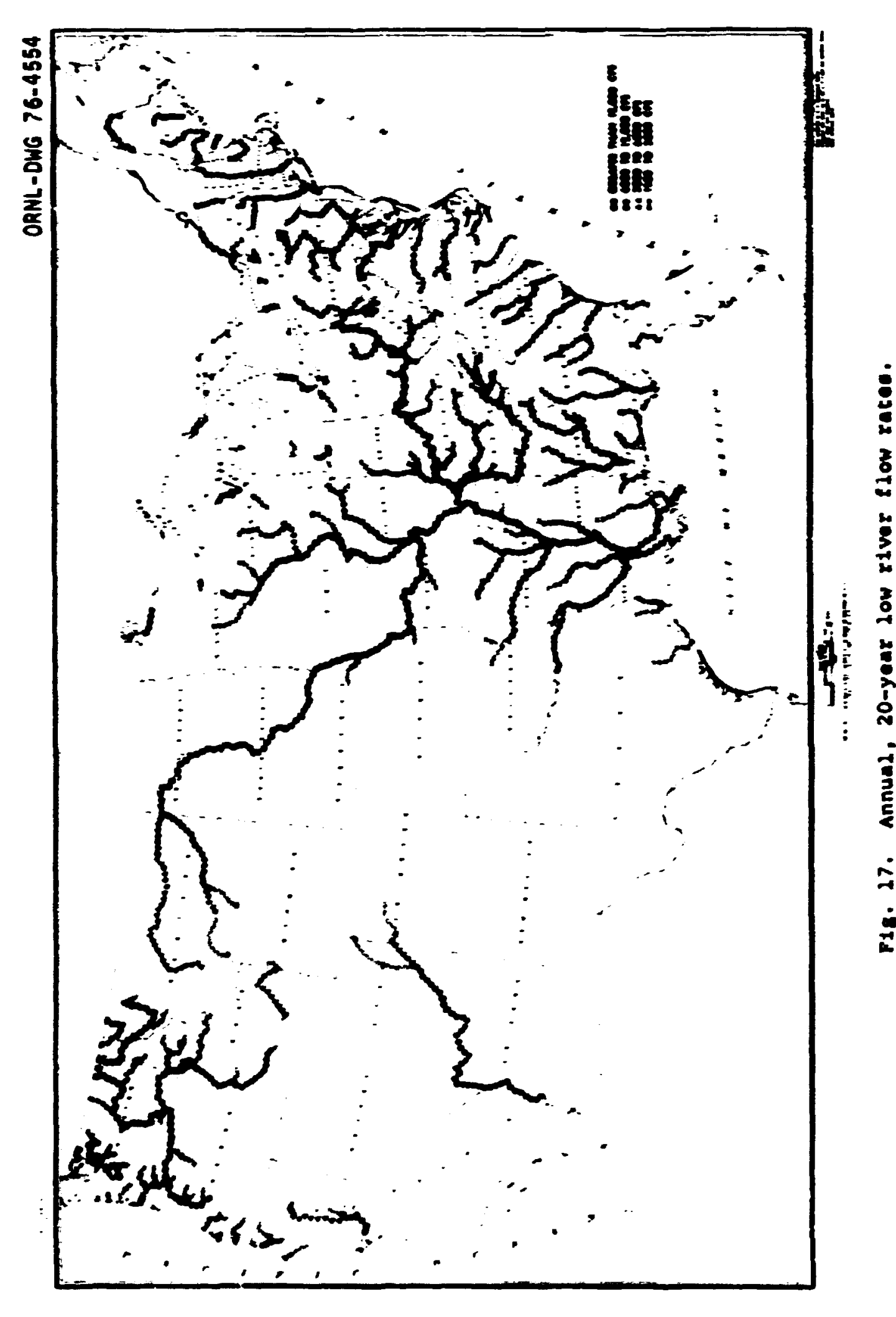




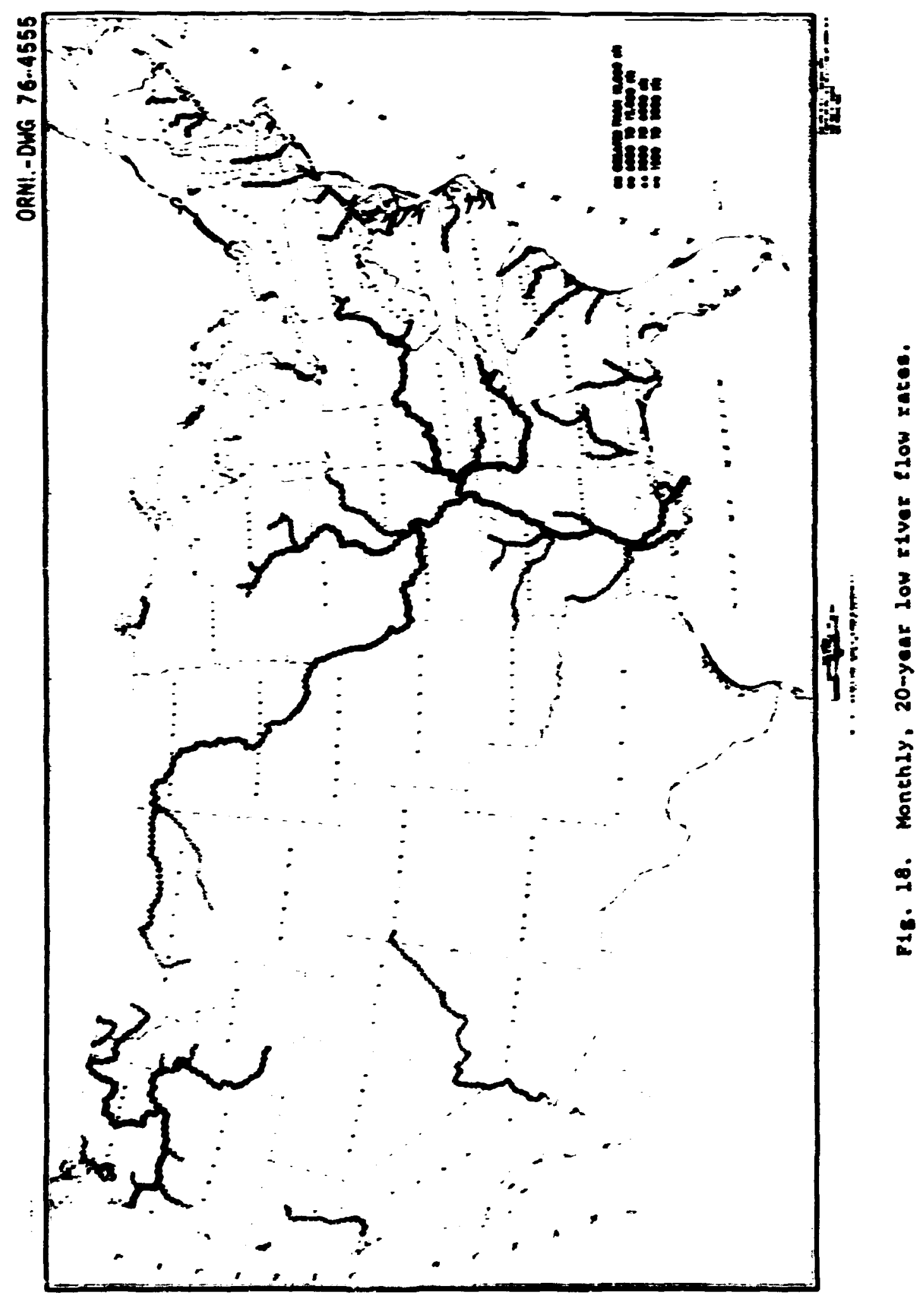


these basins is insufficieat for an energy center. Thus, any vater utilization in chis region would have to be at the expense of other uses. Arother exmple is the Snake River. The upper Snake River in eastern Idaho and westem Hyoming is shown in Fiks. i6 and 17. However. west of Pocatello, Idaho, large Irrigation uses and losses stu the min channel to ground water flow reduces the ilou telow the level sequired for energy cen.ers for about 100 miles. Also, as show in Fig. 14. there are other large areas of the country that have been identified by the URC as water critical areas. Thus, the location of energy centers in these regions my requite establishment of priorities for the use of available water resources or the use of alternative covling exthods. such as dry cooliag towers, or, where available, the use of searater.

\subsection{Data Soures, Linitations, and Interpretations}

Several sources of data vere uned in deternining the river flows.

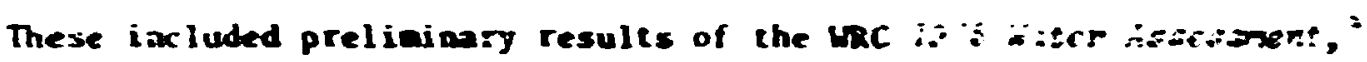
the comprehensive framework studies of various river basir. comaissions (e.g.. the Columbia-Xorth Pacific," the Ohio," or ite lover Mississippi $\left.{ }^{13}\right)$, LSCS data from vater supply papers and computer capes, and the

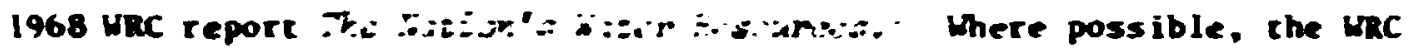
A7s is. 5 isseszar: data vere used; however, these data are cabulated on an area basis, which in many cases, includes several rivers. Ar exaople of this zype of data is show in Table 7 for arc region 01 , ageregated subarea 01, which incluces the St. John, Arcostcook. Penubsent. keancbec, and Androscogeins Rivers in Maine. The table shows the mean inflow and outflow on an anaul basis as well as for each wonth and the prubabilities $(0.30,0.2 n, 0.90$, and 0.95$)$ of a given flow being exreeded. Although the data fur areas that combine the flou of several rivers dn nut provide data for individual rivers, it dnes give the prohability of annual flows. The 0.95 probability yalues give an extinate of the linu flow to be expected I year out of 20 years, and the difference hetween the cutflow and inflow gives the probihi i itg if runoff fror the irra. Konchly flows are significaltly influenced by lakes and rescrvoirs 
Table 7. Surface water supply atectetica for reglon 01, agszegate subarea $01^{a}$

\begin{tabular}{|c|c|c|c|c|c|c|c|c|c|c|}
\hline \multirow[b]{3}{*}{ Period } & \multicolumn{5}{|c|}{ Outf lou fron ascregate eubarea 01} & \multicolumn{5}{|c|}{ Inflow co asgregate suberea $01^{b}$} \\
\hline & \multirow{2}{*}{$\begin{array}{c}\text { Mean } \\
\text { diecharge }\end{array}$} & \multicolumn{4}{|c|}{$\begin{array}{c}\text { Dlecherge with Indlcated } \\
\text { percent shance of baing } \\
\text { excesded us a man }\end{array}$} & & \multicolumn{4}{|c|}{$\begin{array}{c}\text { Diacharge with Indicated } \\
\text { percent chance of beins } \\
\text { exceeci=d as a bean }\end{array}$} \\
\hline & & 30 & 80 & 90 & 93 & diecharge & 50 & 80 & 90 & 95 \\
\hline Annual & 59,400 & 58,900 & 48,000 & 42.600 & 38,200 & 4,100 & 4,100 & 3,300 & 3,200 & 2,900 \\
\hline October & 34,300 & 28,100 & 18,000 & 14,300 & 11,900 & 3,000 & 2,300 & 1,200 & 890 & 680 \\
\hline Novaber & 50,700 & 39,700 & 23,600 & 17.800 & 14,400 & 4.300 & 3,200 & $1 ., 700$ & 1,300 & 970 \\
\hline Deceaber & 55,900 & 45,000 & 27,000 & 20,500 & 16.600 & 2,600 & 2,100 & 1,200 & 900 & 690 \\
\hline Januaxy & 39.200 & 34,700 & 23,900 & 19,800 & 17,000 & 1,100 & 970 & 670 & 340 & 460 \\
\hline February & 37,600 & 32.800 & 22,000 & 17,900 & 15,200 & 840 & 730 & 480 & 380 & 310 \\
\hline March & 53,000 & 47,500 & 32.600 & 26,800 & 23,000 & 1,000 & 830 & 490 & 370 & 280 \\
\hline Apr11 & 152,000 & 140,000 & 100,000 & 84,400 & 74,000 & 10,900 & 9,400 & 6,000 & 4,700 & 3,800 \\
\hline May & 138,000 & 125,000 & 87,200 & 71,000 & 61,200 & 14,800 & 1.00 & 3,900 & 7,100 & 5,100 \\
\hline June & $5 ?, 100$ & 47,300 & 33,100 & 27.600 & 23,900 & 3,700 & $2, .00$ & 1,600 & 1,200 & 900 \\
\hline July & 31,600 & 28,900 & 21,000 & 17,800 & 15,800 & 2,300 & 1,800 & 1,100 & 820 & 610 \\
\hline iuguat & 29,100 & 25,400 & 17,800 & 14,900 & 13,200 & 2,700 & 1,500 & 610 & 370 & $: 70$ \\
\hline Septenber & 30,000 & 24,600 & 16,000 & 12,800 & 10,800 & 2,500 & 1,600 & 780 & 300 & 350 \\
\hline & B. & Approximat & monihly & iotmibuti & on of net & -vaporation & lin inch & a) & & \\
\hline Oct. & Nov. & Dec. & Feb. & Mar. & Apr. & June & July & Aus. & Sept & \\
\hline-0.7 & -2.4 & -2.2 & -1.9 & -1.8 & -1.6 & -1.5 & -0.9 & -0.3 & -0.8 & \\
\hline
\end{tabular}

a Additional statiatica: Surface ares of reservales - 630,000 acres: nat annual aurface Import or export = 0 acre-ft; net annual reservolr evaporation rate - -18 in.

bif different fron upstrean aceregate aubara outflow.

Source: U.S. Hater Resou-ces Counc11, 1975 Water Aesesement, to be published. 
on the rivers; thus, the area data cannot be directly applied to obtain the probability of monthly flows.

The procedure used to estimate the individual river flows in this region was to obtain the mean annual flow from UScS data. The annual, 20-year low river flow was then calculated by multiplying the USGS mean annual flow by the ratio of the low annual flow expecced 1 year in 20 years (the annual flow with an 0.95 chance of being exceeded) to the mean annual flow from the WRC regional data. This value was then checked with the USCS data. The estimated monthl:, 20-year low flow was obtained by examination of menthly USCS data for the rivers. This estimate was made by visual exmination of the data, and no detailed statistical analysis was made.

There are many regions in which the WRC 1975 Assessment data can be used directly. An example is shown in Table 8 for region 10, aggregate sujarea 0S, for the Missouri River between the Montana-North Dakota boundary and the Ft. Randall Dam (in southern South Dakota near the junction of the Missouri River and the Nebraska state line). The inflow to this area is the flow from aggregate subarea 04, the Yellowstone River, and aggregate subarea 01, the Missouri River at the Montana-North Dakota boundary. Thus, for this area, one has the mean annual flow, the annual, 20-year low flow, and the monthly, 20-year low flow at various locations along the river. The flow in the headwater areas, such as the upper end of the Yellowstone River in area 1004, is estimated from USCS and WRC data as for the case with the Maine Rivers.

The data of Table 8 (in combination with that of the upstream aggregate subarea 01 and $0: 4$ ) show some characteristics of western rivers, in which stream regulation has a significant effect on flow conditions. The mean annual inflow to the area is $22,800 \mathrm{cfs}$ and the annual, 20-year low inf low is $13,100 \mathrm{cfs}$, as compared with outflows of 23,700 and $11,800 \mathrm{cfs}$ respectively. Thus, while the mean annual flow increases slightly, the water use and evaporation exceeds the indigenous supply during dry years. The monthly (February), 20-year low flow of $2800 \mathrm{cfs}$ shows the effect of $\mathbf{r}$ iver flow regulation and a problem in interpreting the data. The low February inflows to the area are 9100 and $3100 \mathrm{cfs}$, 
Table 8. Surface water aupply atatiatica for region 10 , aggregate aubarea $05^{a}$

A. Summary of streamflow statistics

\begin{tabular}{|c|c|c|c|c|c|}
\hline \multirow[b]{3}{*}{ Perind } & \multicolumn{5}{|c|}{ Outflow from aggregate aubarea 05} \\
\hline & \multirow[b]{2}{*}{ Mean discharge } & \multicolumn{4}{|c|}{$\begin{array}{c}\text { Discharge with ladicated percent chance } \\
\text { of being exceeded as a mean }\end{array}$} \\
\hline & & .50 & 80 & 90 & 95 \\
\hline $\begin{array}{l}\text { Anaual } \\
\text { October } \\
\text { November } \\
\text { December } \\
\text { January } \\
\text { Februery } \\
\text { March } \\
\text { April } \\
\text { May } \\
\text { June } \\
\text { July } \\
\text { Auguet } \\
\text { September }\end{array}$ & $\begin{array}{r}23,700 \\
30,500 \\
26,500 \\
13,300 \\
11,300 \\
9,500 \\
14,200 \\
23,900 \\
27,300 \\
27,200 \\
31,800 \\
34,900 \\
33,700\end{array}$ & $\begin{array}{r}23,700 \\
28,400 \\
22,500 \\
12,200 \\
10,300 \\
7,900 \\
12,400 \\
21,500 \\
26,500 \\
25,300 \\
30,800 \\
33,900 \\
32,700\end{array}$ & $\begin{array}{r}17,800 \\
20,400 \\
14,000 \\
8,800 \\
7,200 \\
4,700 \\
8,100 \\
14,600 \\
21,600 \\
18,200 \\
24,500 \\
26,900 \\
25,900\end{array}$ & $\begin{array}{r}15,000 \\
17,400 \\
10,900 \\
7,200 \\
5,900 \\
3,600 \\
6,400 \\
12,000 \\
19,400 \\
13,500 \\
21,600 \\
23,700 \\
22,900\end{array}$ & $\begin{array}{r}11,800 \\
15,300 \\
8,700 \\
6,300 \\
5,100 \\
2,800 \\
5,300 \\
10,300 \\
17,700 \\
13,600 \\
19,700 \\
21,600 \\
20,900\end{array}$ \\
\hline
\end{tabular}

B. Approximate monthly distribution of evaporation as a feroent of the net onnual rate

\begin{tabular}{cccccccccccccc}
\hline Oct. & Nov. & Dec. & Jan. & Feb. & Mar. & Apr. & May & June & July & Aug. & Sept. & \\
\hline 12 & 4 & 1 & 0 & 1 & 1 & 4 & 6 & 9 & 20 & 23 & 19 & 9 \\
\hline
\end{tabular}

additional atctistics: Surface inflow to aggregate abarea - outflow from aggregate subareas ol and 04 (reglun 10); surface area of reservolrs - 973,000 acrea; net annual surface 1 mport or export - 0 acre-ft; net anaual reeervolr evaporation rate $-28 \mathrm{in}$.

Source: U.S. Warer Reoources Counc1l, 1975 Water Aseresment, to be publlshed. 
or a minimum total of $12,200 \mathrm{cfs}$ (this value is a minimu and would be this low only if the inflow from the two upstream areas were a minimum in the same year). Thus, rather large quantities of vater are stored during this period. An examination of USGS data for intermediate points in this area indicates that water is stored in most of the min stem reservoirs in this region (primarily Garrison, Oahe, and Ft. Randall, having reservoir capacities of $24.4 \times 10^{6}, 23.6 \times 10^{6}$, and $5.7 \times 10^{6}$ acre-ft respectively) during the winter. Reference 13 states that releases of water during the winter (from late November to late March when ice condicions prevent use of the river for navigation) are made to maintain satisfactory downstream water quality. The water impounded during this period is released during the 8-month navigation season to maintain adequate channel depth. It is also interesting to note that the total storage capacity of the min stem reservoirs is over $75 \times 10^{6}$ acre-ft, or greater than three times the mean annual flow from the lowermost dam. Thus, che extensive development of the Missouri River Basin has a pronounced effect on seasonal flow and has sufficient capacity to influence annual flows.

The low February flow also brings out a problem in relating the water flow rates of Figs. 17 and 18 to the generating capactly that the river can support. The criteria for flow without storage would limit the number of reactors to nine. Hovever, the lowest flow occurs only in February when the watc $\dot{r}$ consumption rate is considerably less than the $30 \mathrm{cfs} / 1200$-Me plant typical of hot weather conditions, and a total of 11 or 12 reactors could be supplied without consumption exceeding $10 \%$ of the flow. However, if the current winter release rates are just sufficient to provide dilution flow for downstream wastes, then large consumptive uses of water coulo: equire larger winter releases and thus reduce the water aval able for augmenting flows during the navigation season.

In some areas, primarily the Columbia-North Paciftc, the ot io River, and the lower Mississippl River basins, the comprehensive framework studies ${ }^{10-13}$ included detailed statistical data of river flows. The results presented in these studies, aluns, with the WRC data, were used for estimating flcws. 
There is a basic difference in the manner in which the low monthly flows are presented in the various data sources. The comprehensive framework s:udies ${ }^{10-13}$ give 30-day low flows, whereas the procedure used to extract data from the USGS computer tapes gave nonthly averages from which low flows were obtained. The 30-day value implies that the lowest flow over 30 consecutive days was used. This would be lower, in wost cases, than the monthly averaged low flow, but the difference probably would be seall. The WRC data reports low wonthly flows by each specific month and can be different from the 30-day or monthly flows, which can be for any 30 days or any wonth. In wost cases rivars have flow characteristics such that the low flow occurs during one season (usually late sumer or fall), and the differences in the above methods of analysis are probably within about $10 z$.

\subsection{Power Capacity of Major River Basins}

The data presented in Figs, 17 and 18 show those rivers having sufficient flow to support various sizes of reactor complexes, bur. in most cases do not give the limits to the total number of reactors or power plants that the river basin can accomodate. As noted previously, the crittria used for the maps were based on rear-peak water consumption during the sumer and on full-power operation of all units; that is, no consideration was given to plant factor or to seasonal variation in water consumption per unit of uutput.

Although these assumptions are reasonably valio for streams with low flows of 1 ess than 8000 to $10,000 \mathrm{cfs}$, they are too restrictive to be applifed to a large river basin that can support a large number of power plants. For example, WASH-113914 estimates a plant ioad factor of 65 to $70 \%$ for nuclear plants. This inplies that the total installed capacity on a large river system could be lacreased by as much as $50 \%$ or, conversely, the plant factor could reduce the average water consumption to about 20 cís per 1200 me of installed capacity.

In evaluating the power plant capacity that can be instaileci on a river basin, the mix of nuclear and fossil-fired units should be considered. Case A of WASH-1139/4 estimated that, for the year 2000, about 
542 of the total installed generating capacity will be nuclear. For this analysis, the remaining 462 vill be assumed to be supplied by fossil-fired units. Modern fossil-fired plants have a base-load efficiency of about $40 z$ and reject about $50 z$ of the hrat input to the cooling vater. With wet cooling towers, this results in a sumer water consumtion rate of about $18 \mathrm{cfs}$ per 1200 me of power output. However, most power projections assume that the fossil-fired plants will be loadfollowing, which will reduce their load factor and efficiency. The exact efficiency will depend on the degree of cycling and the fraction of full-load operation. The combined effects of the lower part-load ef $f$ iciency and the load tactor for these plants will result in a water consumption rate of abuut $15 \mathrm{cfs}$ per 1200 me of installed capacity. Thus, the sumer water consumption rate for the expected aix of nuclear and fossil-fired plants will be about 17 to $18 \mathrm{cfs}$ per 1200 wie of installed capacity.

Finally, the vater consumtion rate during cold weather conditions will be reduced and will depend on the site location and the mode of operation of the cooling syste during this time. Taking all factors together, 16 cfs per 1260 me of installed capacity becomes a reasonable average value for water consumption on the larger river basins; this value is used in the following analysis.

Table 9 sives estiates of the mean annual flow, the annual, 20-year low flow, and the monthly, 20-year low flow at the outlet of the majur river basins. Also shown is the number of power plants of all types that could be accomodated by these flows if using a required river flow rate of $160 \mathrm{cfs}$ (a consumption rate of $10 \%$ of the low flow condition) per 1200 we of installed capacity. The number of power plants shown for both cases, with and without storage, provides some insight to availability of water resources; a far more detalled analysis of load factors and seasonal timing of peak loads would be required to arrive at firm estimates. For the smaller rivers show in the table, especially those for which less than 20 plants are allowable, the diversity due to plant luad factors may not be fully realized, and the numher of olants may not be quite as large as shown. 
Table 9. Estimated outflow of major U.S. river basins and number of 1200-kile power plants that can be located upstreas

\begin{tabular}{|c|c|c|c|c|c|}
\hline \multirow[b]{2}{*}{ River basin } & \multicolumn{3}{|c|}{ Flow (cfs) } & \multicolumn{2}{|c|}{$\begin{array}{c}\text { Number of power } \\
\text { plants }\end{array}$} \\
\hline & $\begin{array}{c}\text { Mean } \\
\text { annual }\end{array}$ & $\begin{array}{l}\text { Annua!, } \\
\text { 20-year }\end{array}$ & $\begin{array}{l}\text { HonthIy, } \\
20 \text {-year }\end{array}$ & $\begin{array}{l}\text { With } \\
\text { storage }\end{array}$ & $\begin{array}{l}\text { Wi thout } \\
\text { storage }\end{array}$ \\
\hline Connecticut & 18,600 & 11,600 & 2,800 & 72 & 17 \\
\hline Hudson & 24,200 & 15,600 & 4,200 & 97 & 26 \\
\hline Delaware & 24,300 & 14,200 & 3,900 & 88 & 24 \\
\hline Susquehanna & 37,900 & 26,300 & 3,400 & 164 & 21 \\
\hline Apalachicola & 24,200 & 15,200 & 8,000 & 95 & 50 \\
\hline Mobile & 64,000 & 39,800 & 9,000 & 248 & 56 \\
\hline Al abana & 32,400 & 21,100 & 6,700 & 131 & 41 \\
\hline Tombigbee & 32,200 & 18,700 & 1,600 & 116 & 10 \\
\hline Mtssissippi-Atchafalaya & 615,000 & 390,000 & 150,000 & 2437 & 937 \\
\hline Illinois" & 20,600 & 10,500 & 4,800 & 65 & 30 \\
\hline Missouri & 70,800 & 28,300 & 13,400 & 176 & 83 \\
\hline Ohio & 276,000 & 162,000 & 41,700 & 1012 & 260 \\
\hline \multicolumn{6}{|l|}{ Allegheny- } \\
\hline Monongahela & 30,500 & 22,000 & $5,000^{-}$ & 137 & 31 \\
\hline Wabash & 30,500 & 12,100 & 2,100 & 75 & 13 \\
\hline Cumber 1 and & 33,400 & 18,000 & 4,000 & 112 & 25 \\
\hline Tennessee & 63,100 & 48,600 & 23,600 & 303 & 147 \\
\hline Whit $\mathrm{e}^{i \vec{i}}$ & 30,000 & 15,000 & 8,000 & 94 & 50 \\
\hline Arkansas & 39,800 & 11,100 & 2,100 & 69 & 13 \\
\hline Red & 30,500 & 10,100 & 1,600 & 63 & 10 \\
\hline Co lumb ia & 240,000 & 170,000 & 110,000 & 1062 & 688 \\
\hline Snake & 56,200 & 38,200 & 17,400 & 238 & 108 \\
\hline Wi I lame t te & 38,500 & 24,200 & 5,400 & 150 & 33 \\
\hline St. Lawrence & 240,000 & 190,000 & 160,000 & 1187 & 1000 \\
\hline
\end{tabular}

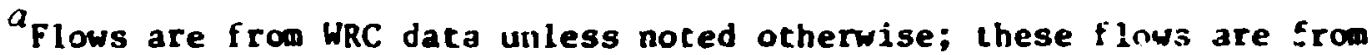
the WRC water regions and in some cases are not the fluw from the mouth of the river.

Erom liscs data.

$\because$ U.S. Army Engineer Division, Ohio River, Ohio kiver Basin Compreireneivestudy, Appendix C:, Cincinnati, Ohio, August 1966.

Lower Mississippi Region Comprehensive Study Coordinacing Committee,

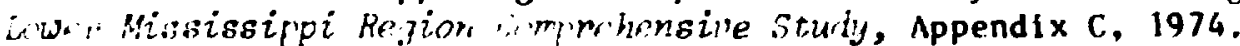

Pacific Northwest River Basins Comission, "Numbia-Worth Pacifir ifyion : mprehensive Framcisork Studu, Appendix $v$, vols. 1 and 2 , Vancouver, Washington, April 1970. 
Table 9 emphasizes the large difference in the annual, 20-year lou flow and the wonthly, 20-year low flow and thus the number of power plants that can be supported with and without storage. This difference ref lects both the seasonal variation in runof $f$ and the degree of development or regulation of the river basin. The "with storage" case does not necessarily require that the power plants be located on a reservoir. It is possible to obtain the sawe results by building upstrean reservoirs to adjust for seasonal variations in flow. However, to reach the total number of plants shown under the "with storage" heading would require that the plants be built on reservoirs or that sufficient storage be provided to eliainate seasonal flow variations. The number of power plants shown under the "without storage" column represents the total number that might be accomodated by the river system with the current degree of regulation; again, for porer utilization a linft of $10 z$ of the monthly, 20-year low flow is used.

The total mean annual runcf $f$ rom the United States (48 s:ates, excludi ig runoff from Canada) is $1,860,000 \mathrm{cfs}^{2}$ The annual, 20-year low flow (ref. 2) for the various URC regions can be calculated at $1,018,000 \mathrm{cfs}$, or about $55 \%$ of the mean. This value is probably lower than the actual annual, 20-year runof $f$ because the dry years are not the same for all regions of the country. Part of this runof $f$ is in small coastal rivers that are too small for power plants, and some is in areas that are unsuitable for other reasons. However, the mean annual flow from the three largest rivers (including runoff from Canada), the Mississippi-Atchafalaya, the Columbia, and the St. Lawrence, 1s 1,095,000 cfs. The annual, 20-year and the monthly, 20-year low flows for these rivers are 750,000 and 435,000 cfs respectively.

The total Installed power capacity for the United States in the year 2000 is estimated to be about 1,575,000 MHe (from case A of WASH$1139), 14$ or the equivalent of 1312 plants, each producing 1200 Me. By using the same assumptions for wate. as above, total consumption would be about $21,000 \mathrm{cfs}$, which requires a total river flow of $210,000 \mathrm{cfs}$. In practice, since part of this capacily will be provided by hydroeleccric power and part will be cooled by seawter, the freshwater requirements for fower plant cooling need not place a serious burden on the 
total amount of water avallable. Furthernore, some fraction of the water evaporated will be returned to the contineat as additional precipitation downind of the NECs, and part of this will show up as increased runoff to the various river basins. In sumary, any restrictions on power plants due to water availability restit frov the distribution rather than the total avallability of resources. 


\section{REGIONLL MATER RESOURCES AND REQUIREIENTS}

There are several ways to anelyze vater resources for power require-ments. One method is rather broad and comares the overall availability of vater (as determined by runoff) to the denand. A second, wore site-specific approach is concerned with the distribution of water, the concentration of runof $f$ in rivers and streans, and the ecologicai fmpact of large energy centers on the flows. Either of these approaches must address the question of the reliability of runof $f$ and streasflows. The following analysis of regional water resources discusses both aspects with primary emphasis on streanf lows and the identification of rivers with sufficient flow to support various sizes of energy centers.

Some perspective of possible problems in providing for future pover growth can be obtained by considering future power density requirenents (megawatts per square mile). The projected pcwer capacity requirenents for the 48 contiguous states for the years 2000 and 2020 are $1,575,000$ and 3,000,000 me respectively. With an area of 3,000,000 sq miles, the power densities are $0.53 \mathrm{mWe} / \mathrm{sq}$ mile and $1.0 \mathrm{mWe} / \mathrm{sq}$ mile. A power density of $1.0 \mathrm{MHe} / \mathrm{sq}$ mile will consume water, at full-power output, at the rate of $0.025 \mathrm{cfs} / \mathrm{sq}$ mile, or, expressed in terms of runoff, about $0.34 \mathrm{in}$. per year. Including overall plant factors and allowing for lower water consumption during cold weather reduces this value to about $0.18 \mathrm{in}$. per year for each $1 \mathrm{me} / \mathrm{sq}$ mile of installed capacity. The average runof for the United States is about $8.4 \mathrm{in}$. per year.

Another way of getting an overall vitw of future power requirements and the relative merits of energy centers 18 to determine the area that can be served by centers of various sizes. For example, with a power density requirement of $1 \mathrm{mWe} / \mathrm{sq}$ alle, a 1200-MWe plant will serve $1200 \mathrm{sq}$ miles and, if the plants are assumed to be located in a rectangular pattern across the country, would require one 1200-Mie unit every 34.6 miles. Comparable distances for energy renters of $f$ ive, ten, and forty $1200-$ Me units would be 77,110 , and 219 miles respectively. There are wide variations in power density requirements throughout the country, and some regions can use the output of large energy centers in relatively small areas. 
In exaninang the regional water iesources and requirements for power, a total of eleven regions were used. These regions follow the general outline used in the National Atlas except that states are not split between regions. A list of the regions and the states inciuded in each are shown in Table 10. Table 10 also gives a compilation of vater data for each region and projections of installed power capacity for the year 2020. The water data are given in terns of inches per year, cfs, and cfs per capita, and, with the exception oz the per capita data, are for both the average and the annial, 20-year low flow (or runoff). The per capita data are for the annual, 20-year low flow and 1970 census data. The sooling water consumption rates for the installed capacity for the year 2020 are based on an annual corsumption rate of $16 \mathrm{cfs}$ per 1200 me of installed capacity. The distance between various sizes of energy centers is based on a simple rectangular pattern of sites and capacity projections for the year 2020 .

In the following discussion of rejional water resources, primary exphasis is placed on the avallability of resources in comparison with requiremetits tor power generation. The political, econcaic, ant environmental problems associated with the development of water resources and the use of land for power plants and transmission corridors, although very important in some areas of the country, are not addressed here.

\subsection{Northeast Region}

The northeast region has the highest, and least variable, runof f (inches per year) of any region in the country. The total runoff averages $186,000 \mathrm{cfs}$, and the annual, 20-year low runoff $18132,00 \mathrm{cfs}$. If all cooling for power generation vere provided by wet cooling towers using fresh water, the consumption by 2020 would be about $3900 \mathrm{cfs}$, or 3.07 of the annual, 20-year low runoff. The region has access to two of the Great Lakes, the St. Lawrence River, the Atlantic Ocean, and over twenty rivers having an annual, 20-year low flow in excess of 1500 r.fs. (Of these rivers, ten have flows greater than $3000 \mathrm{cfs.}$ )

Table $1:$ ists the rivers in or bordering this region which have mean annual flows greater than $3000 \mathrm{cfs}$, annual, 20-year low flows 


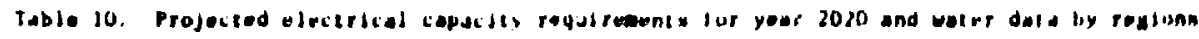

\begin{tabular}{|c|c|c|c|c|c|c|c|c|c|c|c|c|c|}
\hline \multirow[b]{2}{*}{ Metion } & \multirow[b]{2}{*}{ seacos } & \multicolumn{2}{|c|}{$\begin{array}{l}\text { Indsyenous } \\
\text { nn ln yent }\end{array}$} & \multicolumn{2}{|c|}{$\ln \frac{101}{1000} \mathrm{~T}$} & \multirow{2}{*}{$\begin{array}{l}\text { minoll per } \\
\text { inplise } \\
\left(10^{-1}(1,1)\right.\end{array}$} & \multirow{2}{*}{$\frac{- \text { Electids }}{\text { totel }}$} & \multirow{2}{*}{ 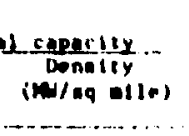 } & \multirow{2}{*}{ 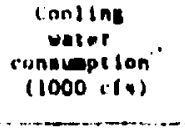 } & \multirow{2}{*}{$\begin{array}{l}\text { sinelus: } \\
\text { unle: }\end{array}$} & \multirow{2}{*}{$\begin{array}{l}\text { anse pet } \\
\text { unti. }\end{array}$} & \multirow{2}{*}{$\begin{array}{l}\text { cencestes } \\
10 \\
\text { unice }\end{array}$} & \multirow{2}{*}{$\frac{4}{40}$} \\
\hline & & Av & $2 \mathrm{~s}^{3}$ & Av & $\therefore \omega^{\prime}$ & & & & & & & & \\
\hline Northeast & 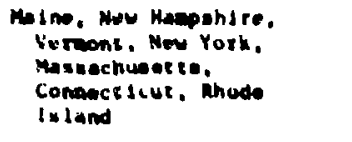 & 21.8 & 13.6 & 146 & 112 & 4.6 & 293 & 2.5 & 3.9 & 22 & 49 & 69 & 139 \\
\hline $\begin{array}{l}\text { Middle } \\
\text { Aelanele }\end{array}$ & 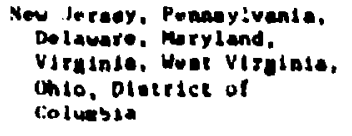 & 16.0 & 10.0 & 202 & 127 & 3.1 & $\$ 16$ & 3.2 & 1.1 & 19 & 63 & 1 & 122 \\
\hline South Acleneic & $\begin{array}{l}\text { North Caroline, Suuth } \\
\text { cerolina. Cieorids }\end{array}$ & 16.2 & 0.4 & 169 & 80 & 1.2 & 266 & 1.7 & 3.3 & 26 & 90 & at & 160 \\
\hline Elurida & Floride & 11.0 & 4.6 & 41 & 14 & 2.0 & 214 & 1.7 & 2.9 & 10 & 41 & 31 & 115 \\
\hline South cenerel & 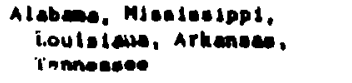 & 18.1 & 9.6 & 324 & 132 & 11.6 & $|s|$ & 1.0 & 3,1 & 36 & 16 & 100 & 210 \\
\hline MIdwexi & 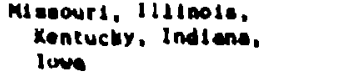 & 10.5 & 4.2 & 200 & $\mathbf{2 0}$ & 3.0 & $36 n$ & 1.4 & 4.9 & 20 & os & 12 & 104 \\
\hline $\begin{array}{l}\text { Worthorn Great } \\
\text { Lakes }\end{array}$ & $\begin{array}{l}\text { Michisan, Uleconein, } \\
\text { Minnequese }\end{array}$ & 1.1 & 4.5 & 113 & 66 & J.3 & 204 & 1.1 & 2.8 & 34 & 15 & 101 & 213 \\
\hline Contral plat nom & $\begin{array}{l}\text { Nebraske, Kanaces. } \\
\text { Colorado }\end{array}$ & 2.4 & 0.9 & 46 & 17 & 2.9 & 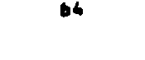 & 0.2 & 0.9 & 10 & $|3|$ & 222 & 463 \\
\hline Soushuent & $\begin{array}{l}\text { Othlahueas, Texen, Mev } \\
\text { Moxiseo, Art soma }\end{array}$ & 2.5 & 0.7 & 101 & 30 & 1.1 & 33 & $0 . n$ & 4.5 & is & 101 & 163 & 226 \\
\hline Northuest & 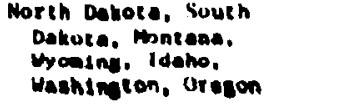 & 0.0 & 3.2 & 374 & 262 & 28.4 & 113 & 0.2 & 1.5 & 12 & 103 & 239 & 310 \\
\hline $\begin{array}{l}\text { Caldiomla- } \\
\text { Grear Basin }\end{array}$ & Wiah, Novene, Callfornda & 6. 3 & 1.8 & 112 & n7 & 2.2 & 312 & 1.1 & 5.0 & 36 & 16 & 107 & 216 \\
\hline
\end{tabular}

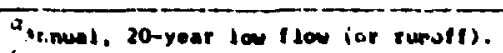

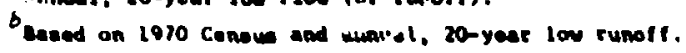

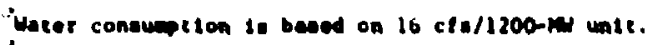

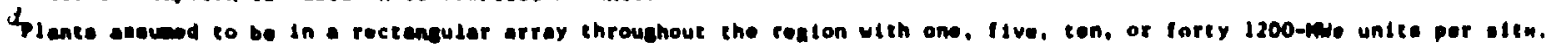


Table 1l. Hater resourcen fur the nurtheset reston"

\begin{tabular}{|c|c|c|c|c|c|c|c|c|c|c|c|c|}
\hline \multirow[b]{3}{*}{ Nuver basins } & \multicolumn{12}{|c|}{ Miver d dow caten (cte) } \\
\hline & \multicolumn{4}{|c|}{ Meon andual tlow } & \multicolumn{4}{|c|}{ Annuel, 20-yuar low tlow } & \multicolumn{4}{|c|}{ Monehly, 20-yoer 100 1100 } \\
\hline & $3000-$ & $\begin{array}{r}6000 \\
12,000\end{array}$ & $12,000-$ & $-24,000$ & $1300-$ & $3000-$ & $\begin{array}{l}6000- \\
12,000\end{array}$ & $>12,0150$ & $\begin{array}{l}1900- \\
3000\end{array}$ & $3000-$ & $\begin{array}{l}6000- \\
12,000\end{array}$ & $.17,020$ \\
\hline \multicolumn{13}{|c|}{ 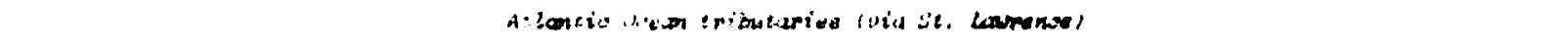 } \\
\hline St. Lavrence & & & & $x$ & & & & $x$ & & & & $x$ \\
\hline Niagere & & & & $\mathrm{x}$ & & & & $x$ & & & & $x$ \\
\hline Cerougee & & & & & $x$ & & & & & & & \\
\hline Unvere & $x$ & $x$ & & & $x$ & $x$ & & & & & & \\
\hline Onelde & & & & & x & & & & & & & \\
\hline Senoca & $x$ & & & & $x$ & & & & & & & \\
\hline Wack & $x$ & & & & $x$ & & & & & & & \\
\hline $\begin{array}{l}\text { Lake Cheoplolin } \\
\text { Mt chel teu }\end{array}$ & $x$ & $x$ & & & $x$ & $x$ & $x$ & & $x$ & & & \\
\hline \multicolumn{13}{|c|}{ Atlume is dewan tmibutarise } \\
\hline $\begin{array}{l}\text { Se. John } \\
\text { Arouetuok }\end{array}$ & $x$ & $x$ & & & $\begin{array}{l}x \\
x\end{array}$ & $\therefore$ & $x$ & & & & & \\
\hline Penobncu: & $x$ & $x$ & $x$ & & $x$ & $x$ & $x$ & & $x$ & $x$ & & \\
\hline Keunets: & $x$ & $x$ & & & $x$ & $\mathbf{x}$ & & & $x$ & & & \\
\hline ditdruscoges in & $\ddot{i}$ & $x$ & & & $x$ & $x$ & & & $x$ & & & \\
\hline Saco & $x$ & & & & $x$ & & & & & & & \\
\hline Wher teac & $x$ & $x$ & & & $x$ & $x$ & & & & & & \\
\hline Sonnect tcue & $x$ & $x$ & $x$ & & $x$ & $x$ & $x$ & & $x$ & & & \\
\hline Mousat on le & $x$ & & & & $x$ & & & & & & & \\
\hline Hudean & $x$ & $x$ & $x$ & & $x$ & $x$ & $x$ & $x$ & $x$ & $x$ & & \\
\hline notiouk & $x$ & & & & $x$ & $x$ & & & & & & \\
\hline De lavere & $x$ & & & & $x$ & $x$ & & & & & & \\
\hline Susquentunne & $x$ & $x$ & & & $x$ & $x$ & & & & & & \\
\hline Chanengo & & & & & $x$ & & & & & & & \\
\hline rhereuns & & & & & $x$ & & & & & & & \\
\hline \multirow{2}{*}{\multicolumn{13}{|c|}{ 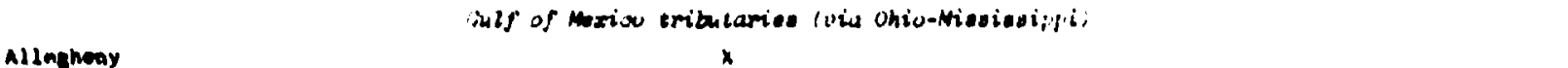 }} \\
\hline Allanghoay & & & & & & & & & & & & \\
\hline
\end{tabular}


greater chan $1500 \mathrm{cfs}$, and wonthly, 20-year low fluws greater than 1500 cfs. The range of flow rates (see figs. 16, 17, and 18) are also indicated for each river. The rivers having annual, 20-year low flows greater than 1500 cfs in this regton are also shown in Fig. 19.

Table 11 can be used as an aid to identify tile rivers shown on the U.S. and regional maps. The rivers are listed under the heading of the ocean (or gulf) to which they cventually flow. For the nurtheast region, the Atlantic Ccean tributaries are listed from north to suth. Inland rivers are listed starting with the river farthest upstream. The tributaries to the Great Lakes are 1 isted as if the Great Lakes were a river system, with the river farthest upstream from the St. Lawrence River listed first. For chose regions in which two rivers combine to form a third, the eastern or northern tributary is listed first.

From an overall regional viewpoint, the northeast has sufficient water resources. The problems associated with the region are described in a WRC report, 6 from which the following quote is taken:

The most serious water supply problem associated with energy development exists in the coastal portion o: the New England and northern portions of the Mid-Atlantic Regions. Whether the development is power plants, ofl terminals, refirerics, tank farms, or other energy developments, the primary problem is the incompatibility of development with the desire for return to or maintenance of a natural environment on the part of a large vocal segment of the population. Reservoirs have been proposed and authorized to solve most of the problems of seasonal variations in stream flow, only to be held up by these naturalists. Siting of ofl terminais in New England has been shunted from site to site by objections of local people to construction at particular sites. These are just examples of the same type of problem which exists with ail types of water resources development whether or not related to energy.

The same WRC report, in reference to the Great lakes, notes that water quility of the lakes is of primary importance with respect to water avallability and that quality, rather than quantity, may serve as a limiting factor in water resources utilization.

This :gion, with its large load centers, is a pitine candidate for large energy centers. From the vicwpoint of water resources, there 


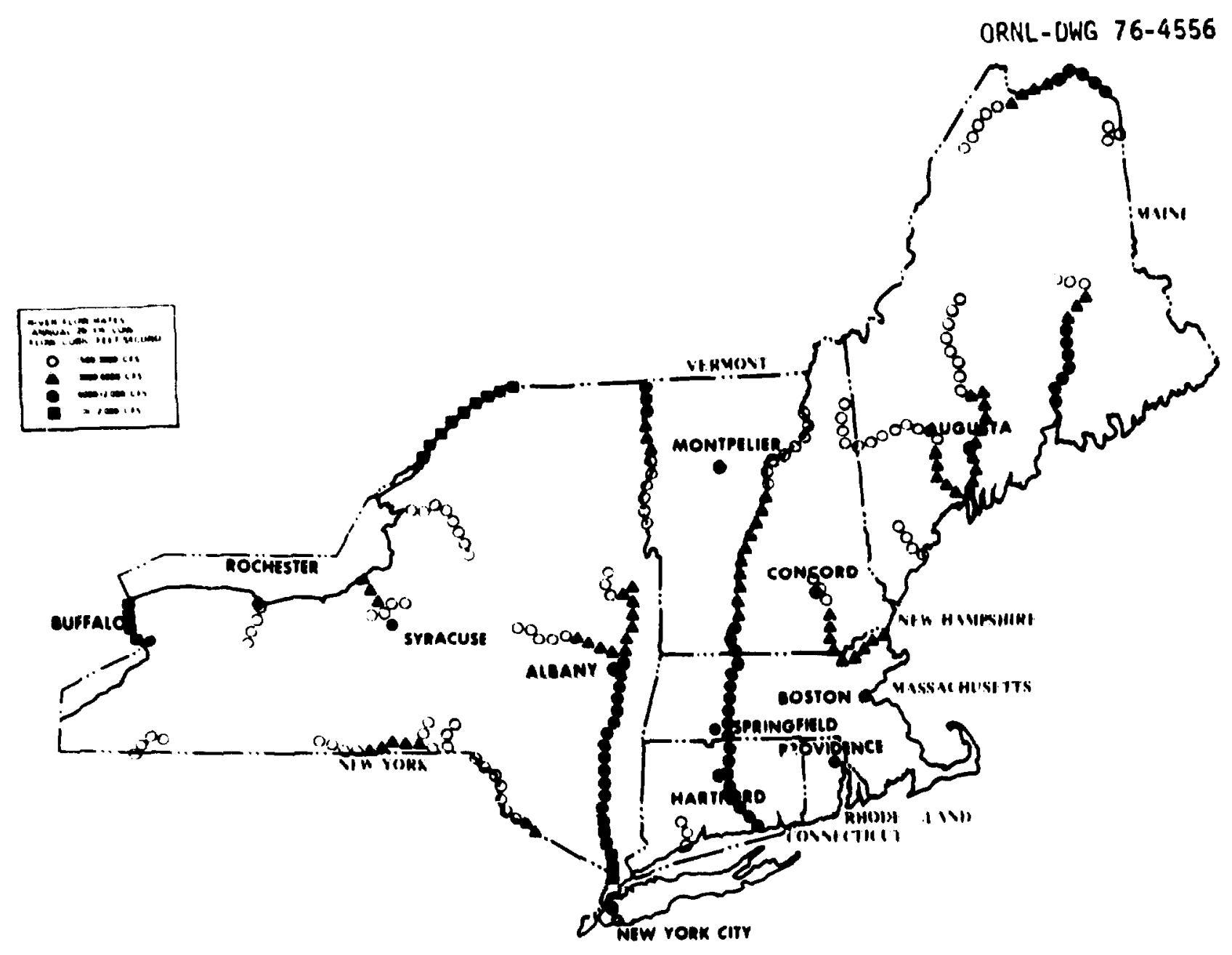

Fig. 19. Rivers having an annual, 20-year low flow great 'r than $1500 \mathrm{cfs}$ - northeast region. 
appears to be little, if any, difference between swall dispersed sites and large centers. In view of the problems currently being encountered in this region, a snaller nuber of very large installations may be preferable.

\subsection{Middle Atlantic Region}

The middle Atlantic region has the largest projected electrical capacity (534,000 me) of any region. The water resources and problems In this region are similar to those of the northeast regicn, and the WRC quotation given in the previous section refers also to this region. The overall total water resources are about the sase as for the northeast, but saller on a per capita basis. The region has access to Lake Erie, the At lantic Ocean, and over twenty rivers having annual, 20-year low flows in excess of $1500 \mathrm{cfs}$. ( $O \dot{\mathrm{i}}$ these rivers, ten have flows in excess of $3000 \mathrm{cfs}$.) This region also has the largest estuaries in the country. However, the general importance of estuaries to the marine life cycle may severely restrict their use as a source for cooling vater.

Table 12 lists the larger rivers in or bordering this region. The criteria for listing, the ranges shown, and the format for identifying rivers are the same as for Table 11. The map of Fig. 20 shows those rivers having an annual, 20-year low flow greater than 1500 cfs.

The distribition of load centers and water resources are fairly well matched in this region. In general, the larger load centers are on, or whthin a short distance of, water supplies sufficient to serve their needs. For example, there are five load centers that require the capacity equivalent ts 30 or more 1200-Me units. Thtse are NewarkJersey City, Philadelphia, Washington, Cleveland, and Pittsburgh. Newark-Jersey City is on the lower Hudson River and the Atlantic Ocean; Philadelphia is on the Delaware River and within about 50 miles of the Atlantic Ocean; Washington 18 on the Potomac and within about 75 miles of the lower part of the Susquehanna River; Cleveland is on Lake Erie; and Pittsburgh is on the Ohio River. Thus, this area is especially well suited for large energy centers. 


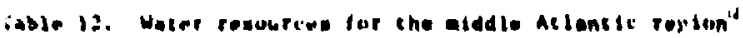

\begin{tabular}{|c|c|c|c|c|c|c|c|c|c|c|c|c|}
\hline \multirow[b]{3}{*}{ Aiver banine } & \multicolumn{12}{|c|}{ Hiver (tow ratex (s) In] } \\
\hline & \multirow[b]{2}{*}{$\begin{array}{c}1000- \\
0000\end{array}$} & \multicolumn{2}{|c|}{ Men annuel flow } & \multirow[b]{2}{*}{$.34,000$} & \multicolumn{4}{|c|}{ Annual, do-yoar lan llow } & \multicolumn{4}{|c|}{ Honehiy, 20-year lon flow } \\
\hline & & 12,000 & $: 2,000$. & & $\begin{array}{l}1300- \\
2000\end{array}$ & $\begin{array}{l}1000- \\
0000\end{array}$ & $\begin{array}{l}.000)= \\
12,000\end{array}$ & $\cdot 12,0010$ & $1300-$ & $\begin{array}{l}3000- \\
6000\end{array}$ & $\begin{array}{l}1000- \\
11,000\end{array}$ & 212,000 \\
\hline \multicolumn{13}{|c|}{ 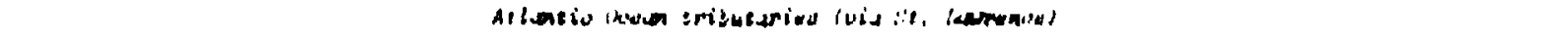 } \\
\hline Moume. & $x^{2}$ & & & & $x$ & & & & & & & \\
\hline \multicolumn{13}{|c|}{ At Imtio a wem eribularies } \\
\hline Muduan & & & $x$ & & & & & $x$ & & $x$ & & \\
\hline Do lavare & $x$ & $x$ & $x$ & & $x$ & $x$ & $x$ & & $x$ & $x$ & & \\
\hline Susqualuenne & $x$ & " & $x$ & $x$ & $x$ & $x$ & $\mathbf{x}$ & $x$ & $\mathbf{x}$ & $x$ & & \\
\hline Chemenges & & & & & $x$ & & & & & & & \\
\hline $\begin{array}{l}\text { Meat Br anch } \\
\text { S sequehanas }\end{array}$ & $x$ & $x$ & & & $x$ & $x$ & $x$ & & & & & \\
\hline Junlets & $x$ & & & & $x$ & & & & & & & \\
\hline Pusconec & $x$ & $x$ & & & $x$ & b: & & & & & & \\
\hline ingens & $x$ & $x$ & & & $x$ & $x$ & & & & & & \\
\hline Roonowike & $x$ & $x$ & & & $x$ & $x$ & & & $x$ & & & \\
\hline man & & & & & $x$ & & & & & & & \\
\hline \multicolumn{13}{|c|}{ 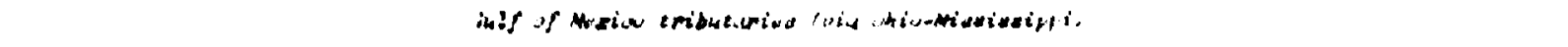 } \\
\hline (nts so & & & & $x$ & & & & $x$ & & $x$ & $x$ & \\
\hline Allegheny & $x$ & $x$ & $x$ & & $\mathbf{x}$ & $x$ & $x$ & $x$ & $x$ & & & \\
\hline Mosongehele & $\mathbf{x}$ & • & $x$ & & $x$ & $x$ & $x$ & & $x$ & & & \\
\hline Tyears Valley & & & & & $x$ & & & & & & & \\
\hline cheal & & & & & $x$ & & & & & & & \\
\hline roughsoegheny & & & & & $x$ & & & & & & & \\
\hline Eeaver & $x$ & & & & $x$ & & & & & & & \\
\hline Mushingere & $x$ & $x$ & & & $x$ & $x$ & & & & & & \\
\hline Kenauna & & & $x$ & & & & $x$ & & $x$ & & & \\
\hline Mon & $x$ & $x$ & & & $x$ & $x$ & & & & & & \\
\hline Couley & & & & & $x$ & & & & & & & \\
\hline ME Siendy & $x$ & & & & $x$ & & & & & & & \\
\hline Sctole & $x$ & & & & $x$ & & & . & & & & \\
\hline Grear Miend & $x$ & & & & & & & & & & & \\
\hline
\end{tabular}




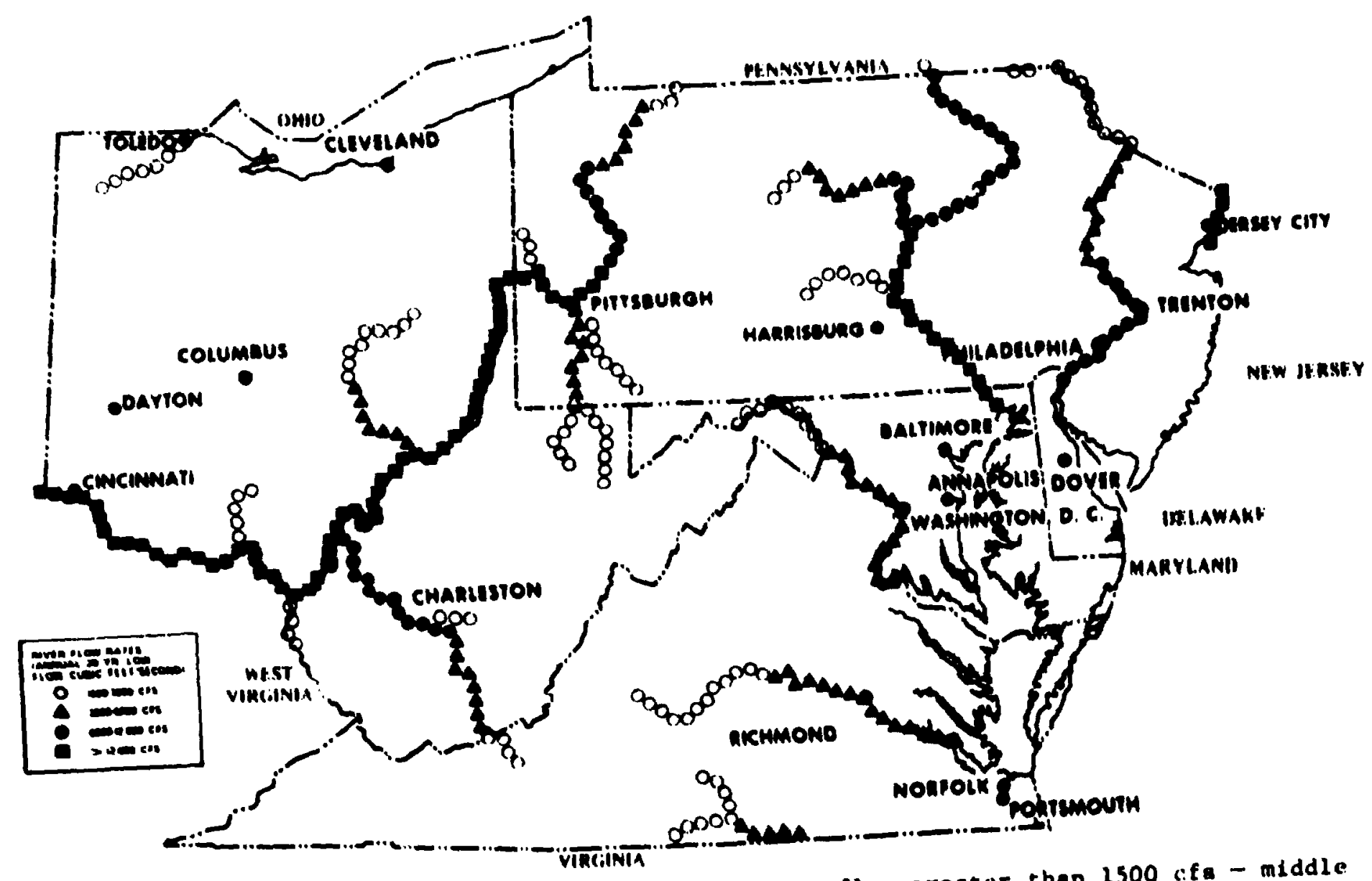

20-year low flow greater than 1500 Atlantic region. 


\subsection{South At lantic Region}

Although the south Atlantic region does not contain acy large river basins, It does contain may saller rivers capable of supporting all energy centers ( 5 to 20 units) and has access to the Atlantic Ocean. The region has one of the higher per capita rumoffs, and water reswurces should be sufficieat to net future requirenents.

A list of the larger rivers in this region is given in Table 13 and the ap of Fig. 21 shows chose rivers having an annul, 20-year low flow greater than 1500 cfs.

This region does have the problen that the large sources of cooling weter are in the constal areas, whereas the major load centers are inland. The largest load center is Atlanta, and the nearest source of cooling water large enough to meet the At lanta requireneat $(60,000 \mathrm{miv})$ in year 2020 is the Tennessee River (about $100 \mathrm{miles}$ avay) in the south central region. Although the loads and water distribution are poorly eatched, the distances involved are not large; therefore, a combination of coastal energy centers and saller, inland, dispersed plants should serve the area without excessive electrical transingsion distances.

\subsection{Florida Region}

Florida has the largest projected density of installed e'ectr fcal capacity ( $3.7 \mathrm{he} / \mathrm{sq} \mathrm{miles)}$ of any region. Furthersore, about 175 of the 214 we projected for the region are concentrated in the southern half of the state - an area short of fresh water and without any rivers capable of supporting even small energy centers. Fortunately, mo part of this region is more than 75 miles from the Atlantic Ocean or the Gulf of Mexico. The load distribution in the southern part of the region is ideal for large coastal energy centers. The northuest part of the region has rather low power requirements, and both fresh and sea water are available for cooling.

A list of the larger rivers in this region is given in Table 14, and the map of $\mathrm{Pig}_{\mathrm{g}} 22$ shows those rivers having an annud, 20-year low flow greacer than $1500 \mathrm{cfs}$. The format for Table 14 is the same as for 


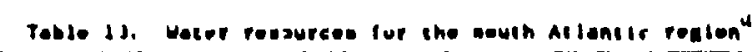

\begin{tabular}{|c|c|c|c|c|c|c|c|c|c|c|c|}
\hline \multirow[b]{2}{*}{ Morer basina } & \multirow[b]{2}{*}{ 10000- } & \multicolumn{2}{|c|}{ man annusl llow } & \multirow[b]{2}{*}{$\times 26,000$} & \multicolumn{3}{|c|}{ Annual, 20-your line 110} & \multicolumn{4}{|c|}{ Monthly, 10-year Iev 1100} \\
\hline & & $\begin{array}{r}1000- \\
12,1000\end{array}$ & $\begin{array}{l}12,0001 \\
26,000\end{array}$ & & 1500. & $\begin{array}{l}1000- \\
0000\end{array}$ & $\begin{array}{cc}0000- \\
12,000\end{array} * 12,000$ & $1900-$ & 10000 & 11,000 & $-12,000$ \\
\hline \multicolumn{12}{|c|}{ 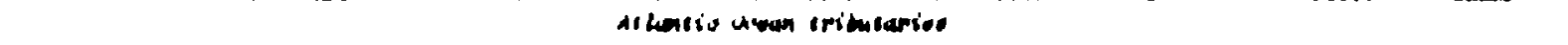 } \\
\hline Moenowe & & $x$ & & & & $x$ & & $x$ & & & \\
\hline moven & $x$ & & & & $x$ & & & & & & \\
\hline Cape rour & $x$ & & & & $x$ & & & & & & \\
\hline reathin-reed bees & $x$ & $x$ & $x$ & & $x$ & $\boldsymbol{x}$ & $\boldsymbol{x}$ & $x$ & & & \\
\hline 218110600000 & $x$ & & & & & & & & & & \\
\hline Cacententwolarese & $x$ & $x$ & $x$ & & $x$ & $\mathrm{x}$ & $\mathrm{x}$ & & $\pi$ & & \\
\hline Conparee & & $x$ & & & & $x$ & & $x$ & & & \\
\hline Drand & $x$ & $x$ & & & $x$ & $x$ & & & & & \\
\hline cooper $r^{n}$ & & & $x$ & & & & $x$ & & $x$ & & \\
\hline Savaracen & $x$ & $x$ & & & $x$ & $x$ & $x$ & $x$ & $x$ & & \\
\hline Altionam & & $\mathrm{x}$ & $x$ & & & $x$ & $x$ & $x$ & $A$ & & \\
\hline oxumes & $x$ & & & & $x$ & & & & & & \\
\hline Ocevilece & $x$ & & & & $x$ & $x$ & & & & & \\
\hline \multicolumn{12}{|c|}{ 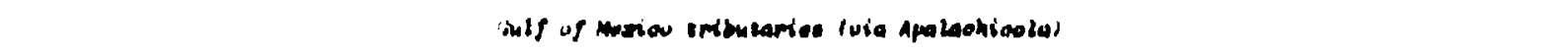 } \\
\hline milat & $x$ & $x$ & & & $\mathbf{x}$ & $x$ & & $x$ & & & \\
\hline Chat r abeochee & $x$ & $x$ & & & $x$ & $x$ & $x$ & x & $x$ & & \\
\hline \multicolumn{12}{|c|}{ 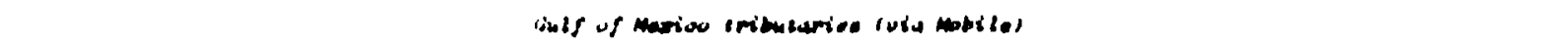 } \\
\hline Cuonen & & $x$ & & & & $x$ & & & & & \\
\hline Dosecanaule & $x$ & & & & $x$ & & & & & & \\
\hline Rlowen & & & & & $x$ & & & & & & \\
\hline \multicolumn{12}{|c|}{ 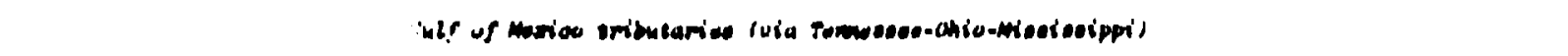 } \\
\hline Dranch oraed & & & & & $x$ & & & & & & \\
\hline Litilde Tomapoese & $x$ & & & & $x$ & & & & & & \\
\hline
\end{tabular}




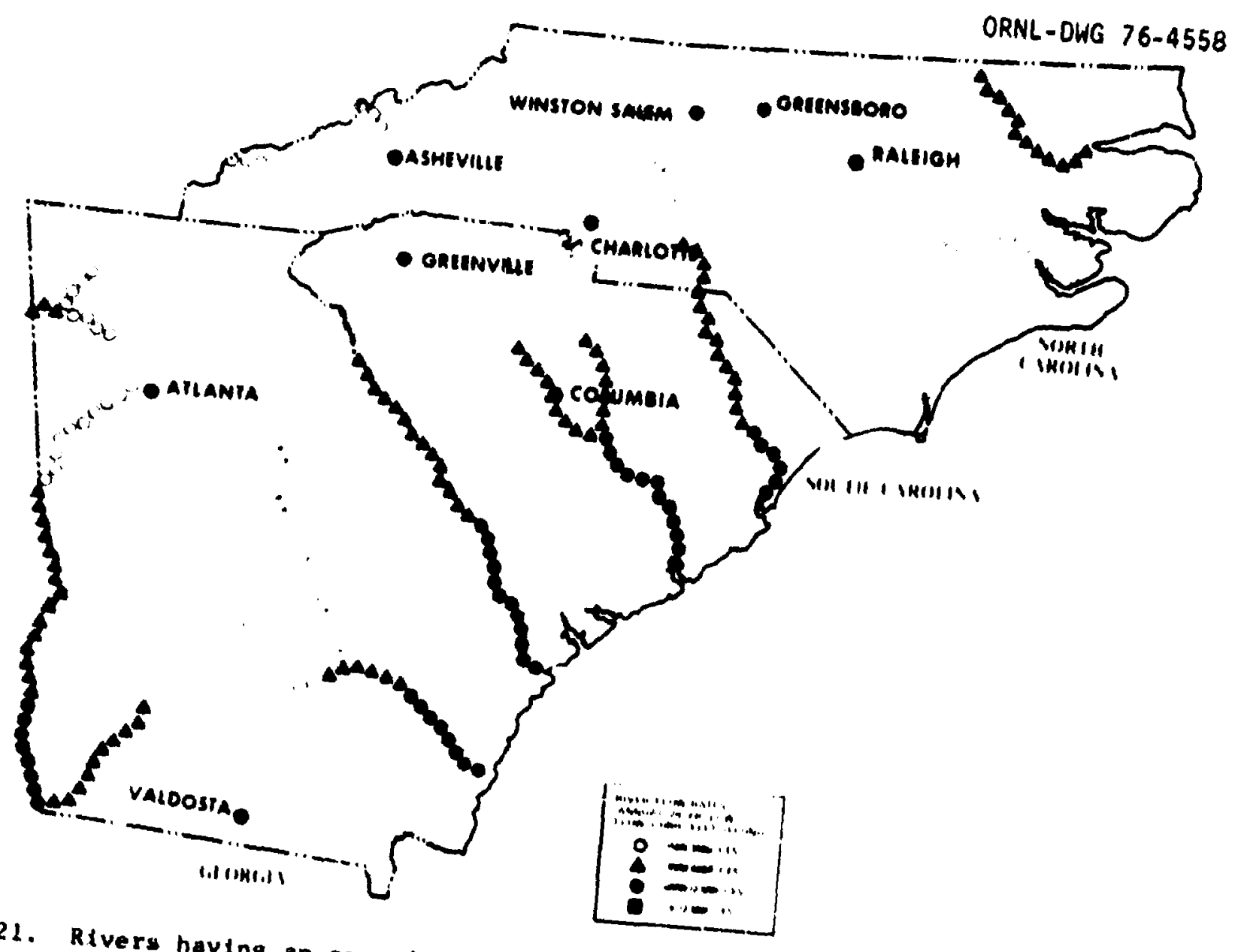

region.

Fig. 2

an annual, 20-year low flow

$$
\text { than } 1500 \text { cf a - south Atbantlc }
$$


Table 14. Hater recources for Vlordda

\begin{tabular}{|c|c|c|c|c|c|c|c|c|c|c|c|c|}
\hline \multirow[b]{3}{*}{ River basing } & \multicolumn{12}{|c|}{ Aiver llow ratas (ale) } \\
\hline & \multicolumn{4}{|c|}{ hean anawel thon } & \multicolumn{4}{|c|}{ Ansual, 20-year low flow } & \multicolumn{4}{|c|}{ Monthly, 20-year low t10u } \\
\hline & $\begin{array}{l}3000- \\
6000\end{array}$ & $\frac{6000-}{12,000}$ & $\begin{array}{l}12,000- \\
21,000\end{array}$ & 224,000 & $\begin{array}{c}1300- \\
3000\end{array}$ & $\begin{array}{l}3000- \\
6000\end{array}$ & $\begin{array}{l}6000- \\
12,000\end{array}$ & 212,000 & $\begin{array}{c}1500- \\
3000\end{array}$ & $\begin{array}{l}3000 \\
6000\end{array}$ & $\begin{array}{l}6000- \\
22,000\end{array}$ & $>12,000$ \\
\hline \multicolumn{13}{|c|}{ Attontio Oaean tributamies } \\
\hline St. Johne & $x$ & $x$ & & & $x$ & & & & & & & \\
\hline \multicolumn{13}{|c|}{ oulf of masioo tributamien } \\
\hline Sunasmes & $x$ & $x$ & & & $x$ & $x$ & & & $x$ & $x$ & & \\
\hline Apalech1cola & & & $x$ & $x$ & & & & $x$ & & & $x$ & \\
\hline Chocrenmatcheo & $x$ & $x$ & & & $x$ & $x$ & & & $x$ & & & \\
\hline zecembla & & $x$ & & & & $x$ & & & & & & \\
\hline Conocuh & $x$ & & & & $x$ & & & & & & & \\
\hline
\end{tabular}

amie reston cosolote of oaly the state of ploride. 


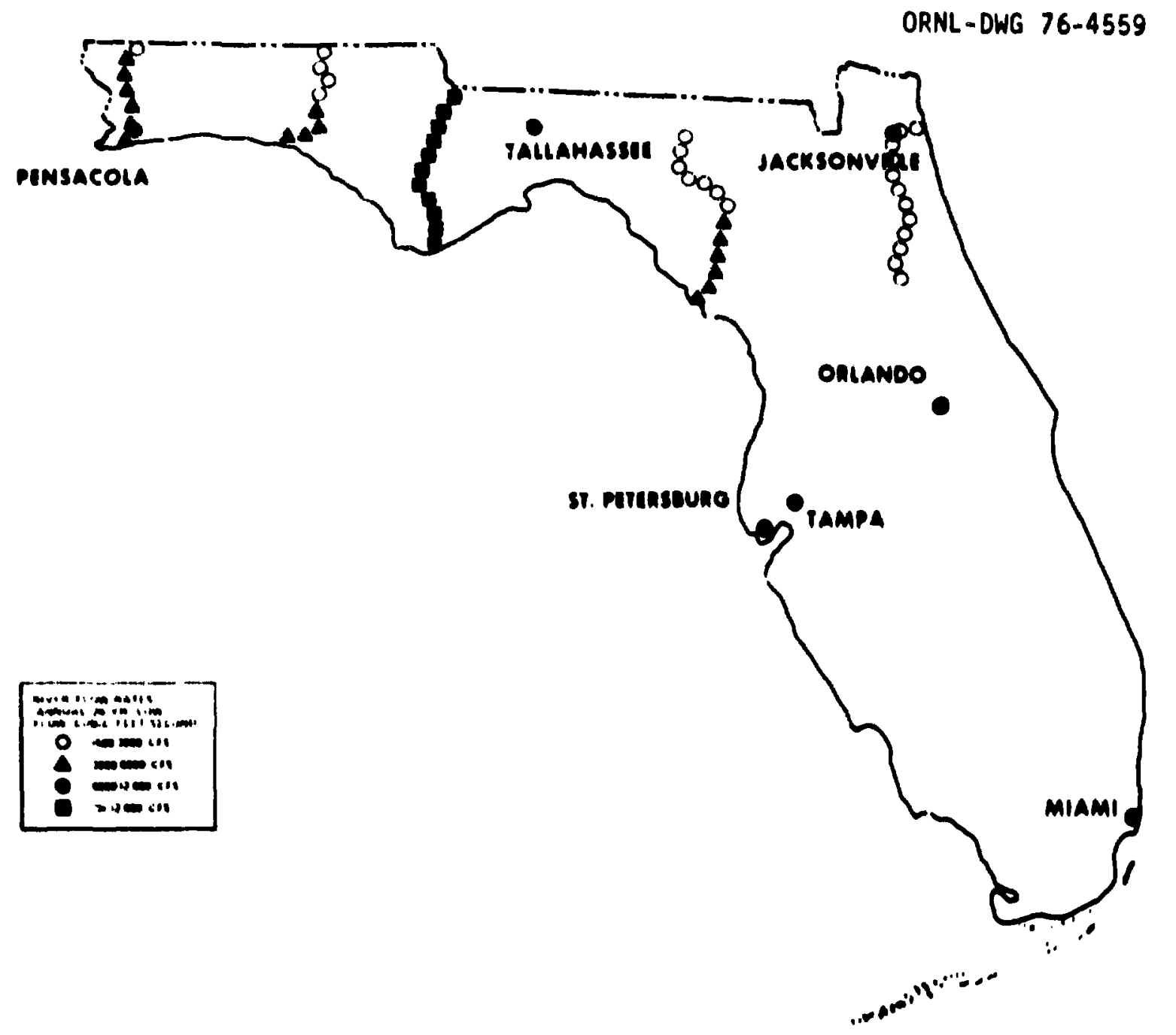

ฮ

Fig. 22. Kjvers having an annual. 20-year luw fluw greater chan 1500 efa - Florida region. 
the previous sections. The Guif of Hexico tributaries are listed frue east to west.

\subsection{South Central Region}

The south central region has an abundant runoff of water plus an enorwous inflow from upstrean regions. Water resources are well distributed throughout the region, axd decisions conceming energy centers vs dispersed sites will not depend on availability of cooling vater: In general, the largest load centers are on rivers having surficient cooling water to met their power requirements.

$A$ list of the larger rivers in this region is given in Table 15 , and the ap of Fig. 23 shows those rivers having an amnul, 20-year lou flow greater than 1500 cfs.

\subsection{Midrest Region}

The indizenuus renoff from the niduest region is not large on a per capica basis or in terms of cocling water reauirements, which are projected to be about $6 \%$ of the indigenous runoff. However, the large inflows to the region frow the ufper parts of the Missouri, Mississippi, and chio Rivers and access to and withdrawals from Lake Michigan by the city of Chicago should be adequate for future requitewents. The water resources avaflable to this rezion are concentrated in large rivers and are well distributed throughout the region. The larger load centers in this region are also located on or near the water resources. This region appears to be especially well suiled for large energy centers.

$A$ Ifst of larger rivers in this region is given in Table 16, and the ap of Fig. 24 shows those rivers with an annual, 20-jear low flow greater than 1500 cfs.

\subsection{Northern Great l.akes Region}

Yost of the cooling water for power generation in the northern rreat l.akes region nust be "upplied by the lakes. Energy-related problems in part of this area any be associaced with water quality and 


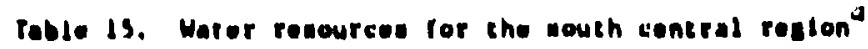

\begin{tabular}{|c|c|c|c|c|c|c|c|c|c|c|c|c|}
\hline \multirow[b]{3}{*}{ River basine } & \multicolumn{12}{|c|}{ Mivor llow rates (cto) } \\
\hline & \multicolumn{3}{|c|}{ Meen annual IIm } & \multicolumn{5}{|c|}{ Annuel, 20-year low flow } & \multicolumn{4}{|c|}{ Monihly, 20-year dou ilou } \\
\hline & $\begin{array}{c}2000- \\
6000\end{array}$ & $\begin{array}{l}1000 \\
12,000\end{array}$ & $\begin{array}{r}12,000- \\
24,000\end{array}$ & $-24,000$ & $\begin{array}{r}1300- \\
3000\end{array}$ & $\begin{array}{r}3000- \\
\$ 000\end{array}$ & $\begin{array}{r}1000- \\
17.000 \\
\end{array}$ & $.12,000$ & $\begin{array}{r}1500- \\
3000\end{array}$ & $\begin{array}{r}000- \\
6000 \\
\end{array}$ & $\begin{array}{l}1000- \\
12,000\end{array}$ & $.12,000$ \\
\hline \multicolumn{13}{|c|}{ in lf of Mustivo emibutamies } \\
\hline Comecuh (vis Racenbla) & $x$ & & & & $x$ & & & & & & & \\
\hline notilo & & & & $x$ & & & & $x$ & & & $x$ & \\
\hline Alabeas & & & $x$ & $x$ & & & & $x$ & & $x$ & $x$ & \\
\hline Coosen & & $x$ & $x$ & & & $x$ & $x$ & & $x$ & & & \\
\hline Tedrepoose & $x$ & & & & $x$ & $x$ & & & $x$ & & & \\
\hline Toed igboe & $x$ & $x$ & $x$ & $x$ & $x$ & $x$ & & $x$ & $x$ & & & \\
\hline Dech Werrlor & & $x$ & & & & $x$ & & & & & & \\
\hline Mulborry Pork & $x$ & & & & $x$ & & & & & & & \\
\hline Paocesonude & & $x$ & & & & $x$ & & & & & & \\
\hline Chrekeserchay & $x$ & & & & $x$ & & & & & & & \\
\hline Lonf & $x$ & & & & $x$ & & & & & & & \\
\hline Peerl & $x$ & $x$ & & & $x$ & $x$ & & & & & & \\
\hline Misesien ippi-Atchateleye & & & & $x$ & & & & $x$ & & & & $x$ \\
\hline Conberiend (vis onlo) & & $x$ & $x$ & $x$ & & $x$ & $x$ & $x$ & & $x$ & & \\
\hline Canoy Pork & $x$ & & & & $x$ & & & & & & & \\
\hline Tennesece (vis Ohlo) & & & $x$ & $y$ & & & $x$ & $x$ & & $x$ & $x$ & $x$ \\
\hline Moleton & $x$ & & & & $x$ & & & & & & & \\
\hline French Droad & $x$ & $x$ & & & $x$ & $x$ & & & $x$ & & & \\
\hline Licele Tanneoses & $x$ & & & & $x$ & $x$ & & & $x$ & & & \\
\hline Clineh & $x$ & & & & $x$ & $x$ & & & $x$ & & & \\
\hline Klveeseses & $x$ & & & & $x$ & $x$ & & & $x$ & & & \\
\hline rath & $x$ & & & & $x$ & & & & & & & \\
\hline Duck & $x$ & & & & $x$ & & & & & & & \\
\hline Marchle & & & & & $x$ & & & & & & & \\
\hline
\end{tabular}


Tabin is (cont inued)

\begin{tabular}{|c|c|c|c|c|c|c|c|c|c|c|c|c|}
\hline \multirow[b]{3}{*}{ Aiver boulne } & \multicolumn{12}{|c|}{ Rivel I lov rased (cla) } \\
\hline & \multirow[b]{2}{*}{$\begin{array}{l}3000 \\
0000\end{array}$} & \multicolumn{3}{|c|}{ Non annuel flow } & \multicolumn{4}{|c|}{ Annual, 20-yuar Jow flow } & \multicolumn{4}{|c|}{ Monthly, 20-year low tlow } \\
\hline & & $\frac{1000}{12.000}$ & $\begin{array}{l}12,000 \\
24,000\end{array}$ & 244,000 & $\begin{array}{l}1500- \\
3000\end{array}$ & $\begin{array}{l}3000 \\
6000\end{array}$ & $\begin{array}{l}1000- \\
1.2,000\end{array}$ & $>12,000$ & $\begin{array}{l}1500- \\
3000\end{array}$ & $\begin{array}{l}3000- \\
0000\end{array}$ & $\begin{array}{l}1000 \\
12,000\end{array}$ & $.12,0013$ \\
\hline Se. Franc to & $x$ & $x$ & & & $x$ & $x$ & & & & & & \\
\hline mite. & $x$ & $x$ & $x$ & $x$ & $x$ & $x$ & $x$ & $x$ & $x$ & $x$ & $x$ & \\
\hline Dleck & $x$ & $x$ & & & $x$ & $x$ & & & $x$ & & & \\
\hline Curteat & & & & & $x$ & & & & & & & \\
\hline Arkaneses & & & & $x$ & & & $x$ & & $x$ & & & \\
\hline Yaroo & & $x$ & & & & $x$ & $x$ & & $x$ & & & \\
\hline 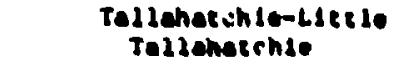 & $x$ & $x$ & & & $x$ & & & & & & & \\
\hline De Dlack & $x$ & & & & $x$ & & & & & & & \\
\hline and & & $x$ & $x$ & $x$ & & $x$ & $x$ & $x$ & $x$ & $x$ & & \\
\hline Hete & $x$ & & & & $x$ & & & & & & & \\
\hline Quachite & $x$ & $x$ & $x$ & & $x$ & $x$ & $x$ & & & & & \\
\hline Sobine & $x$ & $x$ & & & $x$ & & & & & & & \\
\hline
\end{tabular}

$a_{\text {see Table }} 20$ for acalon Included in the nouth cencral ragion. 


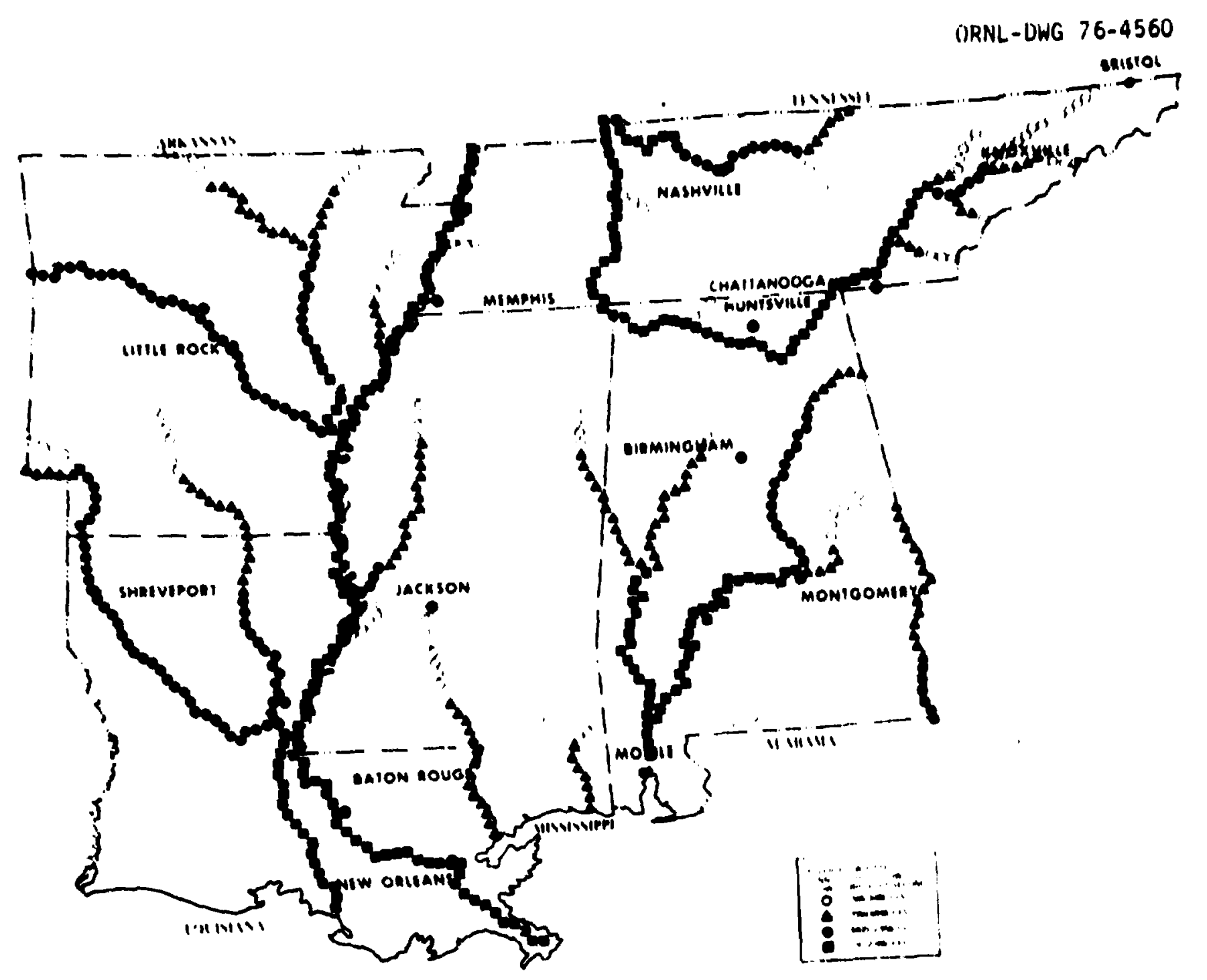

Fig. 23. Rivera having an annual, 20-yeur low flow greater than $15 c 0$ efs - south central region. 


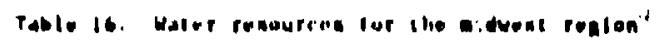

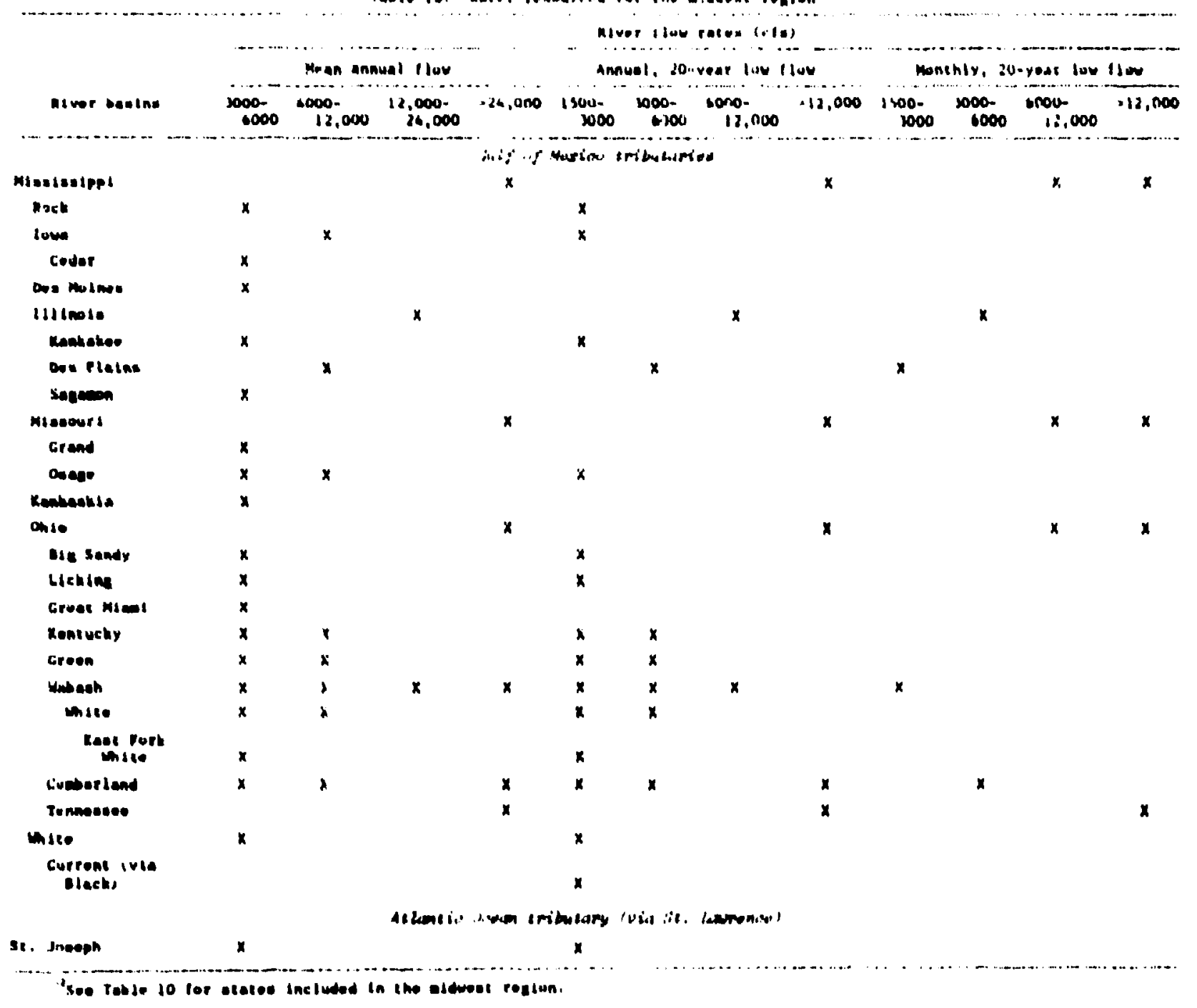




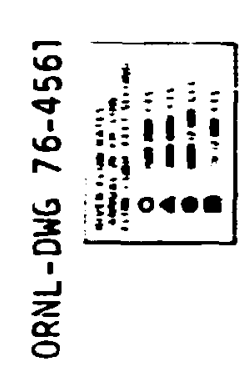


land use. The WRC discussion of developing problens in the Graat Lakes Basin is quoted below: 6

Energy-related water problem in the Great Lakes Region are associated with providing sufficient land for porrer plant sites along the Grtat Lakes and the theraal and perhaps consuptive use effects of additional cooling needs.

The land requirements for porer facilities ust compete with those of other industries, housing, public facilities, ecc. Power facilities ust also overcome opposition from the public and commities which have become facreasingly concerned with the appearance of the surroundings and with the envirosmental quality of the air and landscape.

Hater quality is of prinary ipportance with respect to water availability and ay serve as a linting factor in water resource utillzation rather than a shortage of water per se. The ircreasing use of evaporative cooling neasures should ultimately mininize any thermally induced inpact on water quality.

Water supply problems may arise in certain areas within the Basin; however, with sound water resource managenent, these should not be severe. It must be exphasized that the criteria for lar.d use, in conjunction with water use, sannot be overlooked, and this may be the single most important factor in facilitatiog or restricting future water resource development in the Great Lakes Basin.

The power density characteristics of the region are diverse, with only a few large load centers. The northern part of the region does not appear to be well suited for exergy centers unless centers located in this area send power into the southern and eastern parts of the regiun. The western part of the region has nelther the deand nor the resources for an energy center.

A 1 ist of the larger ifvers in this region is given in Table 1i, and the map of Fig. 25 shows those rivers $h$ :ving an amual, 20-year low flow greater than $1500 \mathrm{cfs}$.

\subsection{Central Plains Region}

The only water resources of zuffictent size to support even a 5-unit complex in the central plains region are along the Missouri River 
Toble 17. Water resources for the northern Great Lakes restion

\begin{tabular}{|c|c|c|c|c|c|c|c|c|c|c|c|c|}
\hline \multirow[b]{3}{*}{$\begin{array}{l}\text { River } \\
\text { bastus }\end{array}$} & \multicolumn{12}{|c|}{ River llow races (cla) } \\
\hline & \multicolumn{4}{|c|}{ Mean anuei flow } & \multicolumn{4}{|c|}{ Annual, 20-yoar low thow } & \multicolumn{4}{|c|}{ Honehly, 20-year low llow } \\
\hline & $\begin{array}{l}3000- \\
n 000\end{array}$ & $\begin{array}{l}6000- \\
12,000\end{array}$ & $\begin{array}{l}12,000- \\
26,000\end{array}$ & $>2 \div, 000$ & $\begin{array}{l}1500- \\
3000\end{array}$ & $\begin{array}{l}3000- \\
6000\end{array}$ & $\begin{array}{l}6,000= \\
12,000\end{array}$ & $>12,000$ & $\begin{array}{l}1500- \\
3000\end{array}$ & $\begin{array}{l}3000 \\
6000\end{array}$ & $\begin{array}{l}6000- \\
12,000\end{array}$ & $>12,000$ \\
\hline
\end{tabular}

At Lantio Docan smibutaries (via St. Lommenoe)

St. Louls

Se. Sary':

St. Joseph $X$

Grand $X$

Pax

Menoninee $x$

St. Cielt

Detrolt

\begin{tabular}{|c|c|}
\hline Mesisetppl & $\mathbf{x}$ \\
\hline Munaore & $x$ \\
\hline st. Crolx & $x$ \\
\hline Chippere & $x$ \\
\hline Hiscoan in & $\mathbf{x}$ \\
\hline
\end{tabular}

$x$

$x$
$x$
$x$
$x$

$x$

Oulf of Marioo tmibutamies $x$

$x$

$x$

$\mathbf{x}$

\section{$x$}

$x$

$\mathbf{x}$

$\boldsymbol{x}$

$x$

$\mathbf{x}$

$x$

$\mathbf{x}$

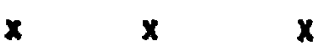

$x$

$x \quad x \quad x$

$x \quad x$

Hudeon Bay tiributamies

Rod

$x$

Relay

$\mathbf{x}$

$\mathbf{x}$

$x$

$a_{\text {See Table }} 10$ for seates lacluded in the northern Great Lakes reation. 


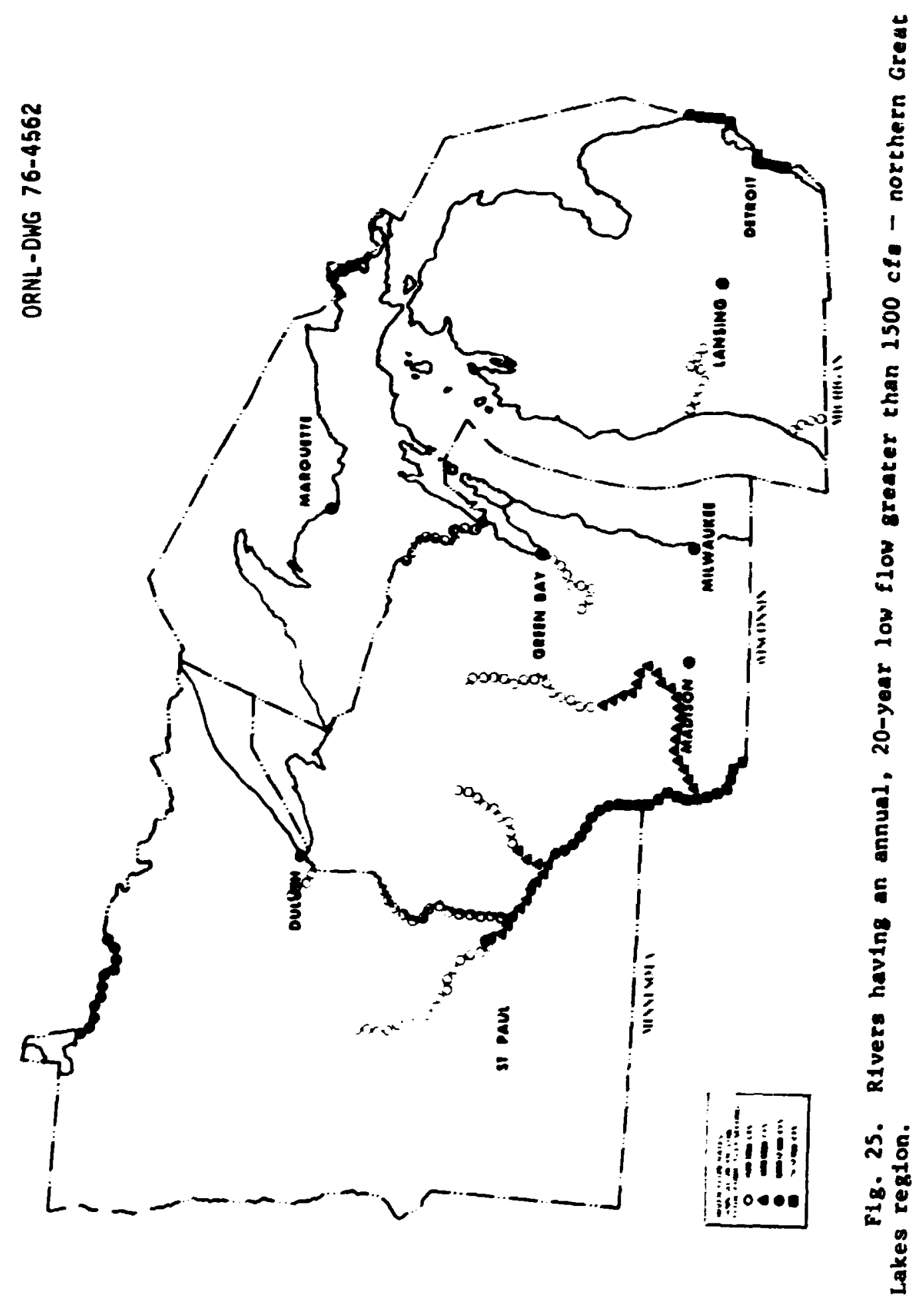


at the eastern boundary of the region. Although the Colorado River is shown in Table 18 and on the ap of the region (F1g. 26), diversion of water fion the lower Colorado is so extensive that the outflow is not sufficient for an energy center. Thus, any utilization of this water would be at the expense of other uses.

This region has neither the resources nor load characteristics for large energy centers to be attractive. The only large load center is the Denver area with a projected capacity of about 30,000 we. The nearest river having sufficient flow to serve this size of load is the Missouri River, about 400 alles away.

The total cooling water consurption required for the projected power requirements is about 27 of the mean annual runoff from the region and about 5 to $6 z$ of the annual, 20-year low runoff. Thus, development of existing water resources should emable the region to weet the projected cooling water requirements with dispersed plants.

\subsection{Southwest Region}

On an overall basis, the southwest region has the lowest per capita runof $f$ and the highest cooling water requirenent, in relation to runof $f$, of any region. The problem is tempered somewhat because nost of the required power capacity and the largest load centers are in the eastern part of the region, which contains mcst of the fresh water resources and which is also within a reasonable distance from the Gulf of Mexico. Large energy centers along the Gulf and smaller centers on the Red and Arkansas Rivers in the extreme easterin part of the region (see Fig. 27 and Table 19) would place about 75 to $85 \%$ of the required capacity within about 250 miles of the demand.

Arizona, New Mexico, and the western part of Texas already have wacer supply pr'-lems, which wi!l probably get worse (see Fig. 14). This area is faced with the alternatives of importing power over long transmission distances, using dry coolling syteas, or obtaining rights to water currently being used for agriculture. 
Table 18. Water reecurces for the central plaine regtona

\begin{tabular}{|c|c|c|c|c|c|c|c|c|c|c|c|c|}
\hline \multirow[b]{3}{*}{ Rtver besins } & \multicolumn{12}{|c|}{ Ruver flow rates (cfa) } \\
\hline & \multicolumn{4}{|c|}{ Man anual tlow } & \multicolumn{4}{|c|}{ Anaual, 20-year low Ilow } & \multicolumn{4}{|c|}{ Monthly, 20-year low tlow } \\
\hline & $\begin{array}{l}3000- \\
5000\end{array}$ & $\begin{array}{l}6000- \\
12,000\end{array}$ & $\begin{array}{r}12,000 \\
24,000\end{array}$ & $>24,000$ & $\begin{array}{l}1500 \\
3000\end{array}$ & $\begin{array}{r}3000- \\
6000\end{array}$ & $\begin{array}{l}6700- \\
12,000\end{array}$ & $>12.000$ & $\begin{array}{l}1500- \\
3000\end{array}$ & $\begin{array}{l}3000- \\
6000\end{array}$ & $\begin{array}{l}6000- \\
12,000\end{array}$ & $>12,000$ \\
\hline \multicolumn{13}{|c|}{ oulf of Mexioo tmibutaries } \\
\hline Paseour 1 & & & $x$ & $x$ & & & $x$ & $x$ & $x$ & $x$ & $x$ & \\
\hline Platte & $x$ & & & & $x$ & $\mathbf{x}$ & & & & & & \\
\hline \multirow[t]{2}{*}{ reases } & $x$ & $x$ & & & $x$ & & & & & & & \\
\hline & & & & P2o & ifio oose & $\infty$ tribu & taries & & & & & \\
\hline Coloredo & $x$ & $x$ & & & $x$ & $x$ & & & $x$ & & & \\
\hline Green & $x$ & & & & $x$ & & & & & & & \\
\hline
\end{tabular}

aseo rable 10 tor etated tacluded in the contral platne reston. 


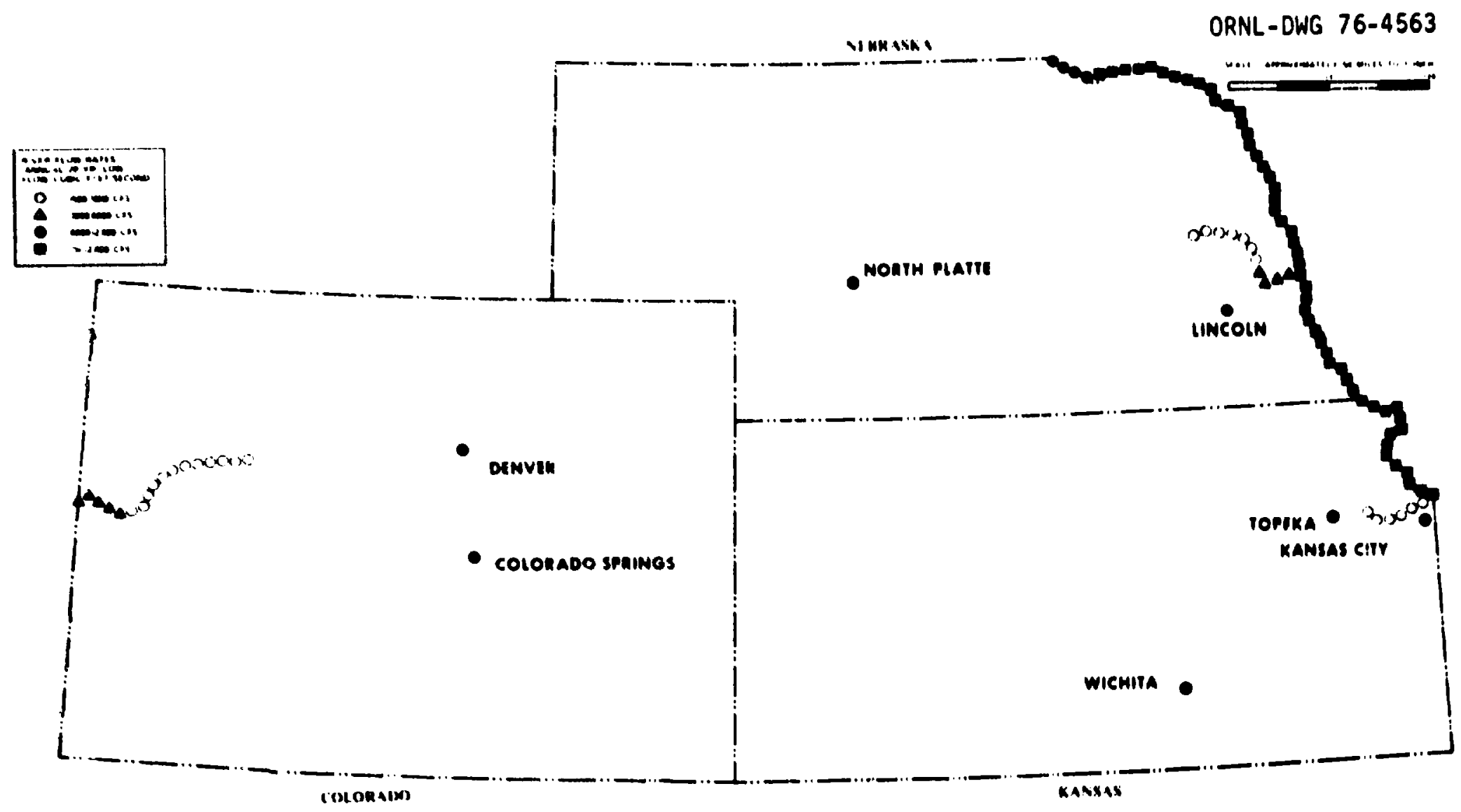

Fig. 26. Rivers having an annual, 20-year low flow greacer than 1500 cfa -- central pluinu regions. 


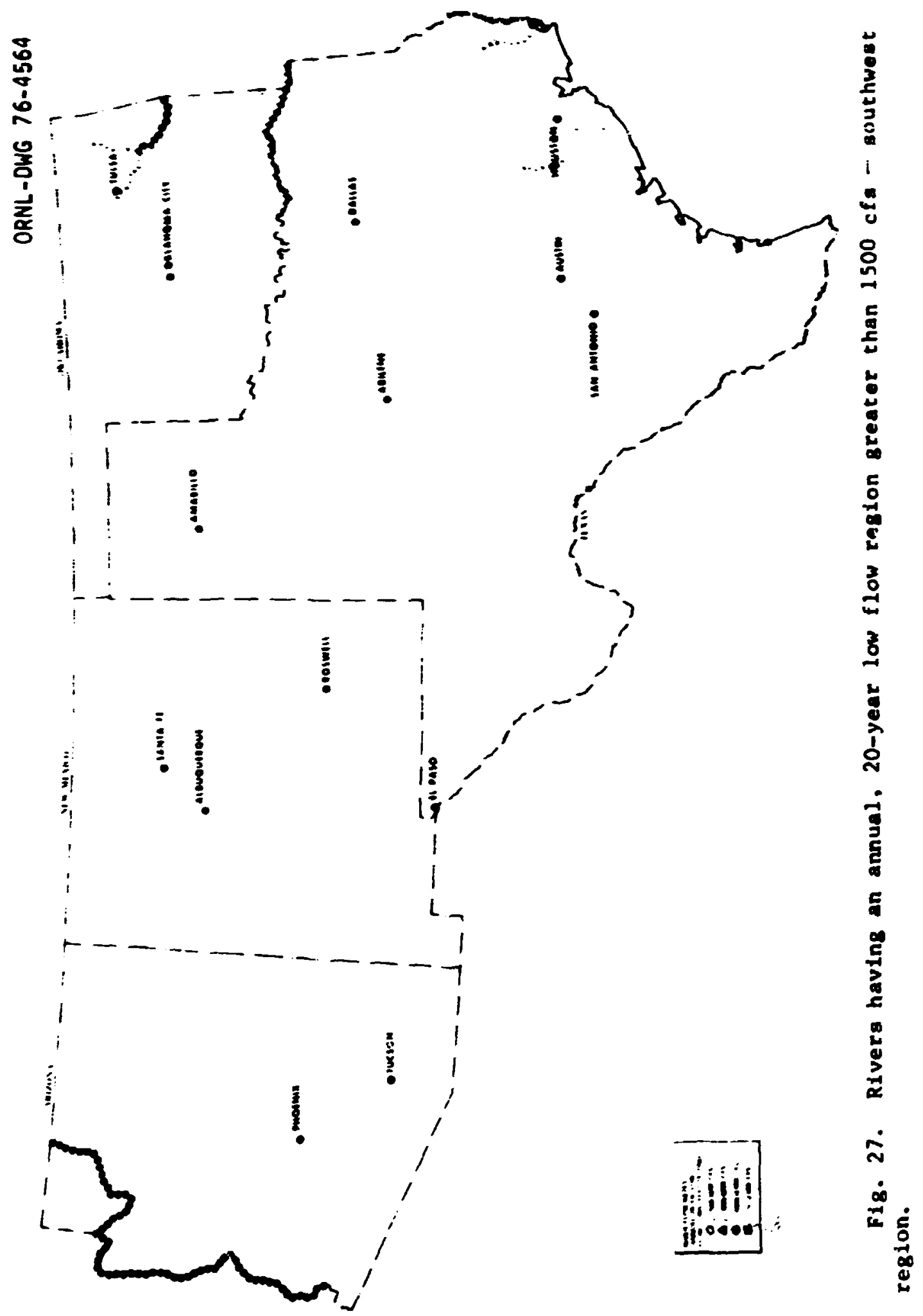


Table 19. Water resources for the southwent reglon

\begin{tabular}{|c|c|c|c|c|c|c|c|c|c|c|c|c|}
\hline \multirow[b]{3}{*}{ Kiver basina } & \multicolumn{12}{|c|}{ River flow rates icls) } \\
\hline & \multicolumn{4}{|c|}{ Mean annual flow } & \multicolumn{4}{|c|}{ Annual, 20-year low flow } & \multicolumn{4}{|c|}{ Monthly, 20-your low Ilow } \\
\hline & $\begin{array}{r}3000- \\
6000 \\
\end{array}$ & $\begin{array}{r}6000 \\
12,000 \\
\end{array}$ & $\begin{array}{r}12,000- \\
24,000 \\
\end{array}$ & $.24,000$ & $\begin{array}{r}1500- \\
3000 \\
\end{array}$ & $\begin{array}{r}3000- \\
6000 \\
\end{array}$ & $\begin{array}{r}6000 \\
12,000\end{array}$ & $>12,000$ & $\begin{array}{r}1500- \\
3000\end{array}$ & $\begin{array}{r}3000- \\
6000\end{array}$ & $\begin{array}{l}6000 \\
12,000 \\
\end{array}$ & $>12.000$ \\
\hline \multicolumn{13}{|c|}{ (inlf of Mexico tributaries (uia Miouiadiphi) } \\
\hline Arkanses & $x$ & $x$ & $Y$ & $x$ & $x$ & $x$ & $x$ & & $\mathbf{x}$ & & & \\
\hline Neceho & $x$ & $x$ & & & $x$ & & & & & & & \\
\hline Verdigise & $x$ & & & & & & & & & & & \\
\hline Canedian & $\mathbf{x}$ & & & & & & & & & & & \\
\hline Red & $x$ & $x$ & & & $x$ & $x$ & & & & & & \\
\hline Lecle & & & & & $x$ & & & & & & & \\
\hline \multicolumn{13}{|c|}{ lintf of Mexice tributarien } \\
\hline Sabine & $x$ & $x$ & & & $x$ & & & & & & & \\
\hline Neclies & $x$ & $x$ & & & $x$ & & & & & & & \\
\hline Tx.nity & $x$ & $x$ & & & $x$ & & & & & & & \\
\hline Brazos & $x$ & $\mathbf{x}$ & & & $x$ & & & & & & & \\
\hline \multicolumn{13}{|c|}{ Pacific Qcean tributarice } \\
\hline Coluredo & & & $x$ & & & & $x$ & & $x$ & & & \\
\hline
\end{tabular}

${ }^{a}$ See Tabla 10 for states included in the southwast region. 


\subsection{Borthuest Region}

The northwest region has the largest runoff of any region. However, mst of the water resources are in the vestern part of the region, whereas the eastern part is expected to have rather critfcal waterrelated energy problees. These probless, as discussed in Ref. 6, are priearily associated with profections of large increases in water requirements for development of the area's shale ofl and coal deposits. Considering the enorzous coal deposits in the area and the fact that foss: 1fired plants require less cooling water than do nuclear plants, nuclear energy centers do not appear to be 1 ikely candidates sor the eastern part of this region.

The western part of the region should have sufficient vater to meet both agricultural and industrial needs. The only two large load areas are around Seattle and in the Willanette Valley. Buth the quantity and distribution of water resources are satisfactory for either dispersed plants or large energy centers.

A list of the larger rivers in this rogion is given in table 20 , and the map of Fig. 28 shows those rivers having an annual, 20-year low flow greater than 1500 cfs. Although the upper Snake River in eastern Idaino and western hyoaing is shown in Fig. 28, large irrigation uses and losses from the main channel reduce the flow below that required for energy centers for about 100 wiles. The feasibility of large uses of water cpstream of this break is questionable. The format used for Tabls 20 is simflar to those for the east coast in that the Paciffc Ocean tributaries are 1 isted from north to south and inland rivers start with the river farthest upstream.

\subsection{California-Great Basin Region}

Most of the future rooling water tiv tha power needs of California and perhaps the Great Basin area will have to be from the Pacific Ocear. Although the map of Fig. 29 and data of Table 21 list the color-ndo and Sacramento Rivers, the Colorado is already comitted to other purposes, and tine California Water Project will divert betwer.n 4 and 5 million 
Table 20. Heter resources for the norelmeat reglon"

\begin{tabular}{|c|c|c|c|c|c|c|c|c|c|c|c|c|}
\hline \multirow[b]{3}{*}{ Rive: beetne } & \multicolumn{12}{|c|}{ River flow roten (cfa) } \\
\hline & \multicolumn{4}{|c|}{ Men enaual d luw } & \multicolumn{4}{|c|}{ Annual, 20-year dow llow } & \multicolumn{4}{|c|}{ Monehly, 20-year low ldow } \\
\hline & $\begin{array}{r}3000- \\
6000 \\
\end{array}$ & $\begin{array}{r}6000- \\
12,000\end{array}$ & $\begin{array}{r}12,000 \\
24,000 \\
\end{array}$ & $>2 h, 000$ & $\begin{array}{r}1500- \\
3000 \\
\end{array}$ & $\begin{array}{r}3000- \\
\$ 000\end{array}$ & $\begin{array}{r}1000- \\
12,000 \\
\end{array}$ & $>12,000$ & $\begin{array}{r}1500- \\
3000\end{array}$ & $\begin{array}{r}3000- \\
6000\end{array}$ & $\begin{array}{r}1000 \\
12,000 \\
\end{array}$ & $\cdot 12,000$ \\
\hline \multicolumn{13}{|c|}{ ou?f of Mrrioo tmibutarios (via Niseineippi) } \\
\hline Mescurl & $\mathbf{x}$ & $x$ & $x$ & $x$ & & $x$ & $x$ & $x$ & $\boldsymbol{x}$ & $x$ & $x$ & \\
\hline Yellavetono & $x$ & $x$ & $x$ & & $x$ & $x$ & $x$ & & $x$ & & & \\
\hline Brenorn & $x$ & & & & $x$ & & & & & & & \\
\hline \multicolumn{13}{|c|}{$\begin{array}{l}\text { Paoifio vesean tmibutaries (via Haght Sound) } \\
x\end{array}$} \\
\hline Snohoentah & & $\mathbf{x}$ & & & & $x$ & & & & & & \\
\hline Skykodeh & $x$ & & & & $x$ & & & & & & & \\
\hline Snoquelate & $x$ & & & & $x$ & & & & & & & \\
\hline Stlllapuentah & $x$ & & & & $x$ & & & & & & & \\
\hline Skasil & $x$ & $x$ & $x$ & & $x$ & $x$ & $x$ & & $x$ & $x$ & & \\
\hline Sauk & $x$ & & & & $x$ & & & & & & & \\
\hline Eakex & & & & & $x$ & & & & & & & \\
\hline Mookeark & $x$ & & & & $x$ & & & & & & & \\
\hline \multicolumn{13}{|c|}{ Paoifio avean tmibutaries } \\
\hline Moh & & & & & $x$ & & & & & & & \\
\hline Quiaheule & $x$ & & & & 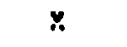 & & & & & & & \\
\hline Chehal te & $x$ & $x$ & & & $\mathbf{x}$ & $x$ & & & & & & \\
\hline Columble & & & & $x$ & & & & $x$ & & & & $x$ \\
\hline Rootenay & & $x$ & $x$ & & & & $x$ & & $x$ & $x$ & & \\
\hline Pead Oreslle & & & $x$ & $x$ & & & & $x$ & & $x$ & & \\
\hline Clark Fork & $x$ & $x$ & $x$ & & $x$ & $x$ & & $x$ & & $x$ & & \\
\hline Flachaed & $x$ & $x$ & $x$ & & $x$ & $x$ & $x$ & & $x$ & & & \\
\hline $\begin{array}{l}\text { South Fork } \\
\text { Plathead }\end{array}$ & $x$ & & & & $x$ & & & & & & & \\
\hline
\end{tabular}


iable 20 (cone Inued)

\begin{tabular}{|c|c|c|c|c|c|c|c|c|c|c|c|c|}
\hline \multirow[b]{3}{*}{ Rlver bentas } & \multicolumn{12}{|c|}{ Aiver flow rotes (cifa) } \\
\hline & \multicolumn{4}{|c|}{ Mean anaual 1100} & \multicolumn{4}{|c|}{ Annual, 20-year lov fiow } & \multicolumn{4}{|c|}{ Monthly, 20-yoar sow t100 } \\
\hline & $\begin{array}{l}3000- \\
6000\end{array}$ & $\begin{array}{l}6000- \\
: 2,000\end{array}$ & $\begin{array}{r}12,000 \\
24,000\end{array}$ & 226,000 & $\begin{array}{l}1300- \\
3000\end{array}$ & $\begin{array}{l}3000- \\
6000\end{array}$ & $\begin{array}{l}6000- \\
12,000\end{array}$ & $>12,000$ & $\begin{array}{l}1300- \\
3000\end{array}$ & $\begin{array}{l}3000- \\
6000\end{array}$ & $\begin{array}{l}1000- \\
12,000\end{array}$ & $\$ 12,000$ \\
\hline \multicolumn{13}{|c|}{ Paoifio } \\
\hline Recte & $x$ & & & & $x$ & & & & & & & \\
\hline Spoleme & $\mathbf{x}$ & $x$ & & & $x$ & $x$ & & & & & & \\
\hline Okenogna & $x$ & & & & $x$ & & & & & & & \\
\hline Wrateches & $x$ & & & & $x$ & & & & & & & \\
\hline Tense & $\mathbf{x}$ & & & & $x$ & & & & & & & \\
\hline Sanke & $\mathbf{x}$ & $\boldsymbol{x}$ & $x$ & $x$ & $\mathbf{x}$ & $x$ & $x$ & $x$ & & & $x$ & $x$ \\
\hline Parecte & & & & & $x$ & & & & & & & \\
\hline Saloon & $x$ & $\mathbf{x}$ & & & $\boldsymbol{x}$ & $x$ & $x$ & & $x$ & & & \\
\hline Clearweter & & $x$ & $x$ & & & & $x$ & & $x$ & & & \\
\hline $\begin{array}{l}\text { morch Pork } \\
\text { Clearwater }\end{array}$ & $x$ & & & & $x$ & $x$ & & & & & & \\
\hline $\begin{array}{l}\text { Kidjle Fork } \\
\text { Clourweter }\end{array}$ & & $x$ & & & & $x$ & & & & & & \\
\hline Lochere & & & & & $x$ & & & & & & & \\
\hline Sollay & $x$ & & & & $x$ & & & & & & & \\
\hline Drechutes & $x$ & & & & $x$ & $x$ & & & $x$ & $x$ & & \\
\hline Willented & $x$ & $x$ & $x$ & $x$ & & $x$ & $x$ & $x$ & $\mathbf{x}$ & $x$ & & \\
\hline $\begin{array}{l}\text { Mulle Pork } \\
\text { Wileste }\end{array}$ & $x$ & & & & $x$ & & & & & & & \\
\hline Meloan 10 & $x$ & & & & $x$ & $x$ & & & & & & \\
\hline Senter & & $x$ & & & & $x$ & & & & & & \\
\hline Dorth santico & $x$ & & & & $x$ & & & & & & & \\
\hline South Seate 100 & $x$ & & & & $x$ & & & & & & & \\
\hline Cleckenenes & $x$ & & & & $x$ & & & & & & & \\
\hline Leats & $x$ & & & & $x$ & $x$ & & & & & & \\
\hline
\end{tabular}


Table 20 (contlinuad)

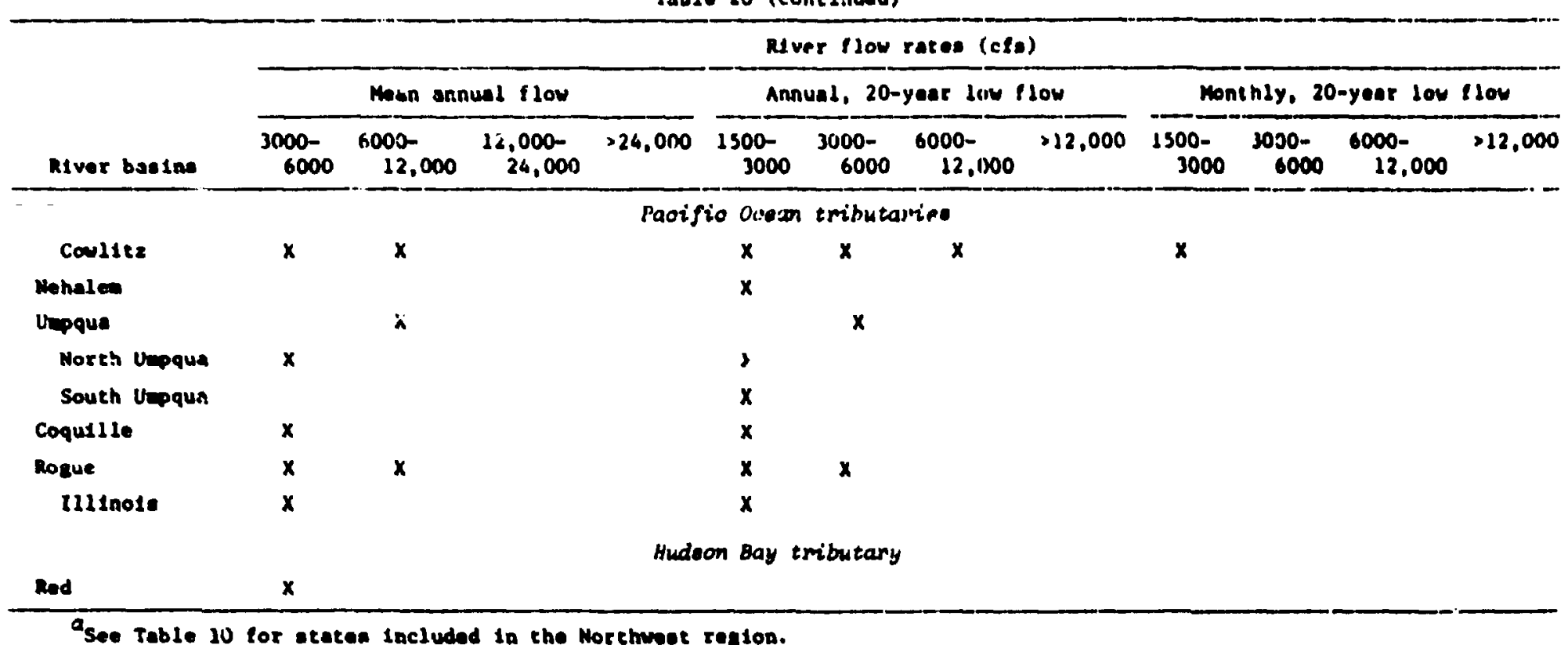

asee Jable 10 tor ateten Included in the Morthmot reglod. 


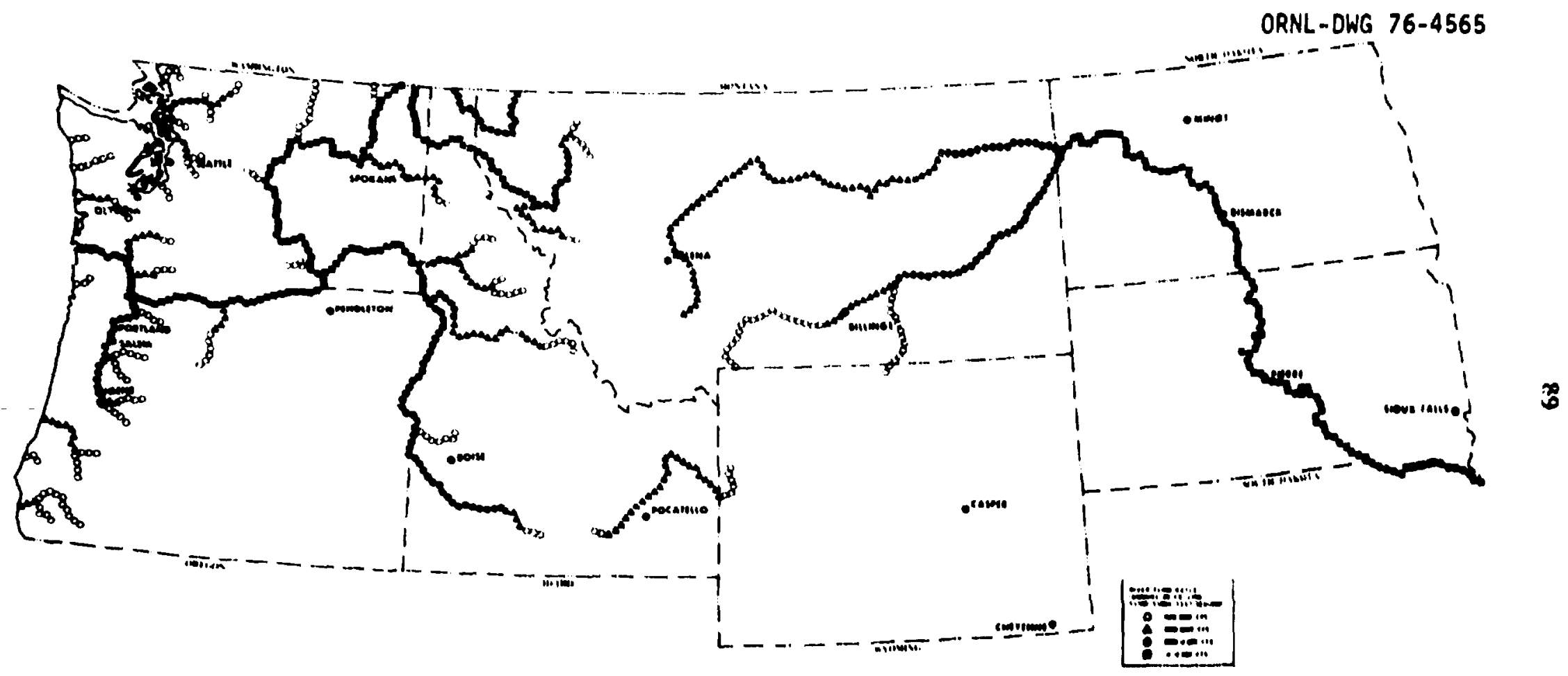

F1g. 28. Rivers having an annual, 20-year low tlow greater than 1500 cfa - nort.hweat reglon. 


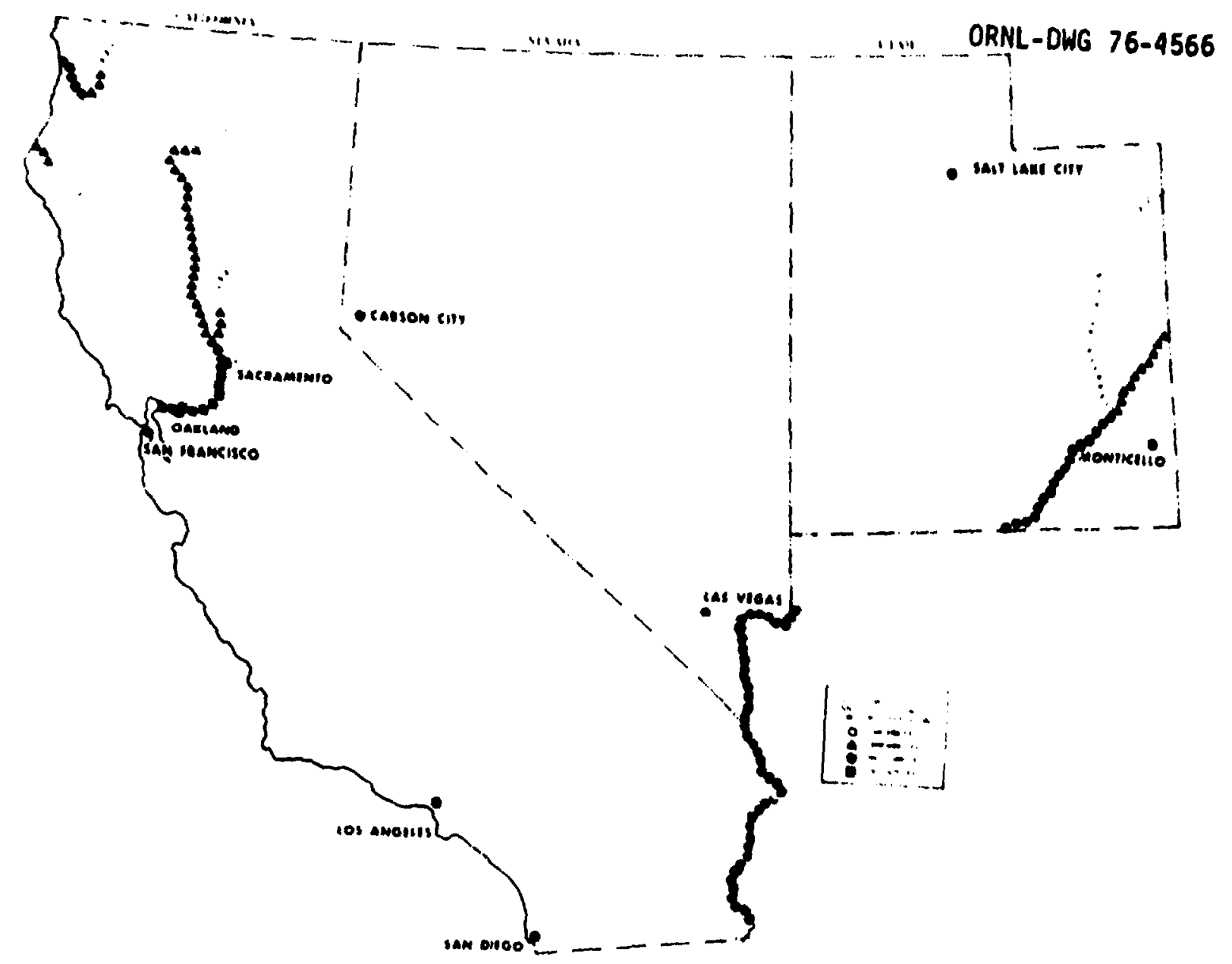
Fig. 29. Rivers having an annual, 20-year low flow greater than 1500 cfo- Callfornia-Great
Basin region. 
Table 21. Water resourcee tor the Colltornda-Great Daein regtona

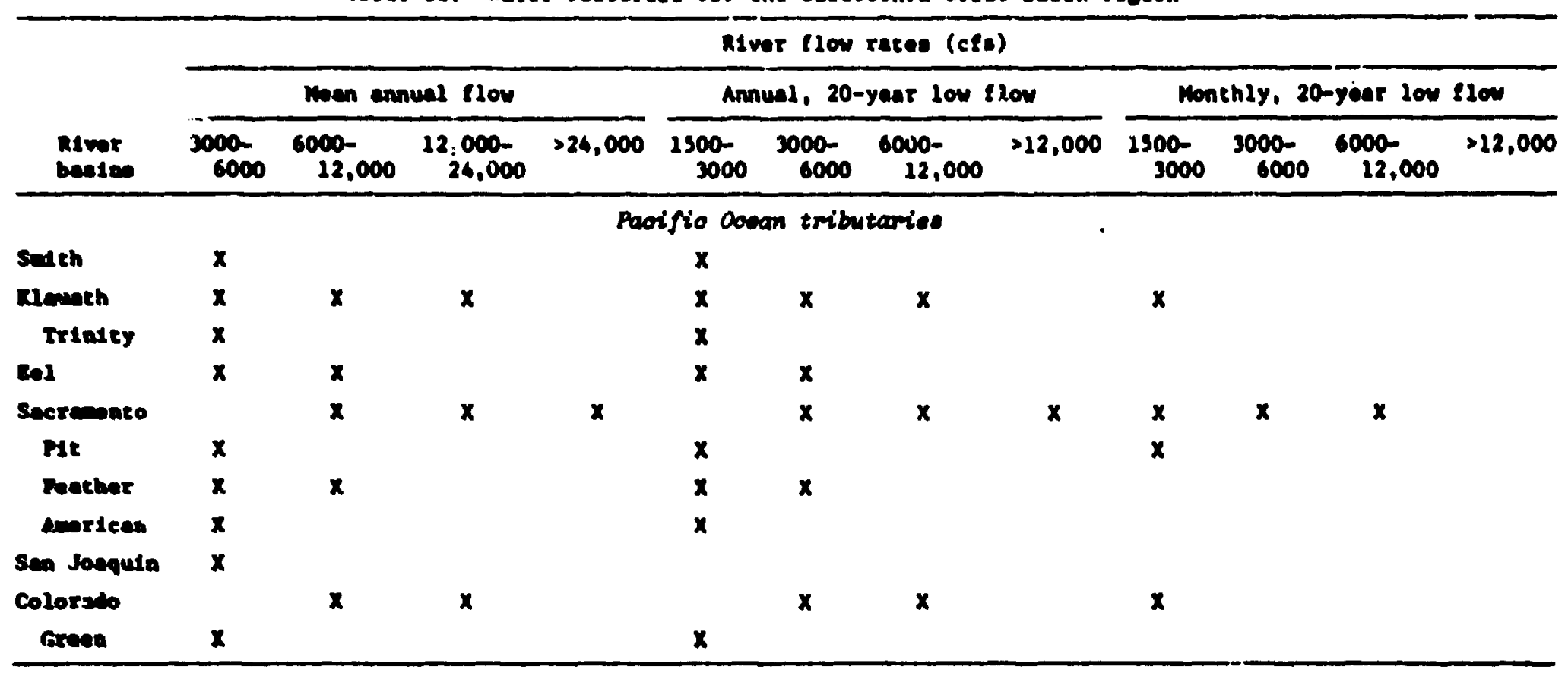

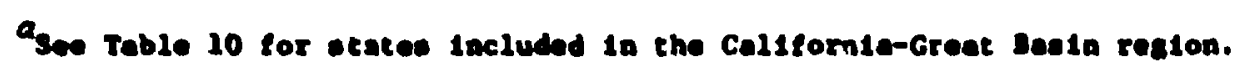


acre-fe of wacer per year from the Sacranento Deita to central and southern Caifforsie, prianily for agricultural purposes. The northern California coastal rivers are rather sali and far from the largest load centers, and the Great Basin area of Nevada and ltah already has water supply probless. The feasibility of large energy centers for this region will depend on finding coastal sites with acceptable seiswic risk, the use of dry cooling systems, or obtaining rights to water currently being used for other purposes. 


\section{Sunerr An concusions}

The quantity of water used for pouner plant cooling will be the same per unit o: output for elther large energy ceaters or all, dlepersed plants. From a wer resources vieupoint, the principal dafference is the larger local water deand of enersy centers, which reatricte the potential sites for these ceaters to relatively large rliers.

The two criterld used for screening purposes to lantify thowe rivers having sufficient flow to be of Interest as potential water sourcas for energy ceaters ephasize the advantages of locazing the centers on rewervolis. The 7-day, 10-year or wonthly, 20-year low flow is about 10 to 202 of the mean amaual flow for any U.S. rivers, wheress

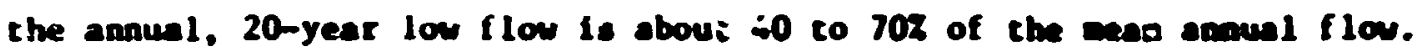
Thus, the use of reservolrs to frovide cooling water durinz periods of low seascnal fimm will increase both the nuber of rivers that can suppist energy centers and the size of energy centers that can be located on che rivers. These differences are readily apparent from Fige. 17 and 18.

The mean annual runoff from the United States (48 states, excluding runoff frce Canada) is about 1,860,000 cfs, and the anounl, 20-year low runoff is about $1,100,000 \mathrm{cfs}$. The area of the 40 states is about $3 \times$ $10^{6} \mathrm{sq}=1 \mathrm{les}$, and the mean ampul rusoff is then $0.62 \mathrm{cfs} / \mathrm{kq}$ alle and the annusl, 20-year low runoff is $0.37 \mathrm{cfa} / \mathrm{aq}$ mile. These values can abso be expressed as 8.4 and 5.0 in. per year reopectively. Part of this runoff is in sall cosstal tivers that are too enell to suppott energy centers, and part will be in areas that are casultable for othar reasons. However, the mean anaul flow from the thres largest ivers (Including runoff from Canada), the Misalibippl-Atchafalaya, the Colubia, and the St. Laurence, 1s 1,095,000 cfs. The amual, 20-year and the wonthly, 20-year low flows for these three rivers are 750.000 and 435,080 cf respectively.

The cotal inscalled electical capactity projected for the United States in the years 2000 anc 2020 is $1,575,000$ and 3,000,000 swe respectively. These correapond to the equivalent of 1312 and 2500 unite 
(1200-rine). The coolin water requirconats ior this capacity, chen considertas the plent land factors. se 1 variation in miter deand. and the alx of moclear and foesil-ficed plancs. will average sbout 16 cfo/1200-mile unit on an anomal basis. The cocai coolise water reguiteents for these yanrs vill be about 21,000 and 40,000 cfs. In practice. part of this capacity will be provided by ingdroelectric statlone, and part uill be cooled by semater. The cocal fresh eater requirements for

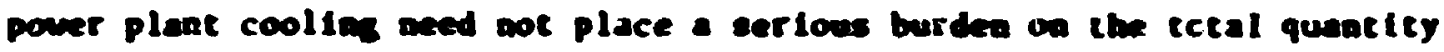
of water avallable. Furthernore, sene fraction of the meter evaphrated will be returned to the contibent as additional prectifitation downit of the necs. and part of this vill show up as facteana ronoff to the varlous rivet basias.

An Intereating enner in which ons can analyze pourer requitrenents and also derive som inalght as to che practicality of large emergy cencers is by the power density requitenents. that is. Che capacl.y requited per square alle. For the year 2020, the projected mast

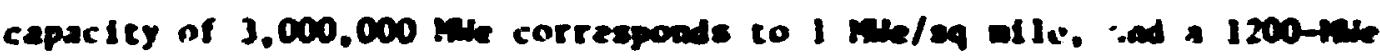
unit vili serve a area of 1200 alles. If plants were visced on a rectanguler pottern acroses the country. thate would be oat glant each 36.6 alles: the distance beturen energy centers of 4,10 , and 40 units would be 69, 110, and 219 alies rapectively. The average anmel cooling

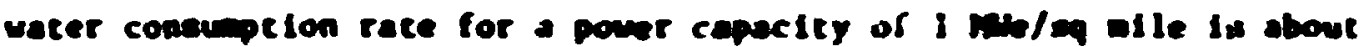
0.18 in. per year, wich is 2.12 of the meas anoual flow and 3.62 of the anmul. 20-year rwaoff for live Unded staces.

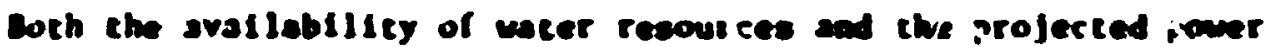
capacily density vary widely acroes the country. The genter resources cast of the hissisulppl hiver are plentiful. These recources inclide the Coreat Lakers. At lantic Ocean. Culf ef Maxlco, and wost of the rivers In the country capoble of supportion easrey centers. The painer denstity requitrmencs in much of this ares are extendive ad wll loceced in relation to the weter rewources for latge energy cencers. Some parts of the heavily populated eastern ciestal areas have had cater supply probleme in receat years. However, these problems are pritarily the resill of Inadequate development of avallable ceter resources rather 
than a lack of resources. The soucharn part of Florida does wot have suffictent frech witer supplice asd w1l have to depead on saneter for power piant cooling.

Bctween the Missiasippl River and the g7th neridian (a line between the eastern border of the bukotas and Dallas. Texnes). the weter resources are much leas pleatiful. However, woet of the larget loed centers is this area are aloas or within a reasable distance of the anjor tivers (Missiselppi, Miseouri, Arkuseas, Red, or Hite) or the culf of Mexico and could be served from large eneres cencers.

The area of the cowatry west of the 97th wer1dian, with ihe excepcion of the Pacific Northnes, has or will heve uater apply problems. There are only three large rivers in this area - the upper Hasourl. Colorado, and Sucrenento. The upper mesourt hiver region to expected to hove critical water supply probles due prtentily to projections of large increaces in vater requirenonts for the developenent of the region's shale oll and cosl deposits. Becaue dinersion of water froe the lower part of the Colorado and Secranento Rivers, primarily for agriculcural furposes. Is extensive. the outflow of these rivers is insuificient to support an eaergy center; therefore, any large utilization of vater from these rivers for emergy centere would be at the expense of otber vese. The electrical loeds and damad deasify in woet of this area are enall and wot well sulted to eares centers. The largeet lood cencers are alone the Callfornte const, and the feasibility of supplying thee loads from large energy centers will depead on fladtre cosetal stees hovios

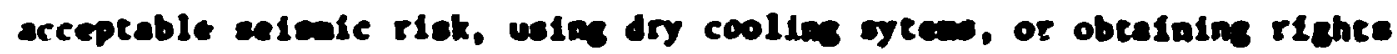
to water curreatly belas used for other purposes.

The Pacifte Dorthuse abould hove eufficleat water to weet both apricultural and iadustial aneds. The oaly two large load centers in this area are around Seatele and in the Willanetce valley. Doth the quentity and distribution of water resources are eatisfactory for either dispersed plancs or large enerey ceaters.

This study das no: Inteaded to discuse national or industial f-inclites for water use. However, It is apporene that rather decalled ling-range piaming will be meeded to resolve conflicting deands on vacer resivu:ces. 
Appendix

TEMIINOLOCY AND CONVERICN FACTORS

Hydrology, like wost disciplines, has evolved its ma cerminolcsy and, like other disciplines, has several sets of units to express quantities. This section defines sone of the terms nost comonly used In studies of water resources and provides conversion tables for the units not comonly used.

Hydrograph: A graph showiag stage, flow, velocity, or other properties of weter with respect to time.

Amaual diacharge hydroraph: A graph of wean daily discharge vs data for a onc-year period (usually October 1 to September 30).

Average flow: The average discharge, usually expressed in cubic feet per second (cfs), for any spec if -ed period of time.

Anneal average flow: The average discharge for any specific year. Meen annual fiou: The average of the avallable (recorded) annual average flows.

Fupoff: That portion of the precipitation that ultimately reaches streans or rivers. Runoif is usually expressed in inches per unit of tine (month or year). For a river basin, runof $f$ is of ten expressed as cublc feet per second per square mile of drainage area (cf sisq wile). The mean annual runoff for the United states east of the 100th meridian Is about $1 \mathrm{cfs} / \mathrm{sq}$ Elle.

Flow duration: The discharge, usually expressed in cfs or cfs/sq wle, that is equaled or exceeded a specific percent of the time; that 1s. the 902 duration flow is that which is equaled or exceeded $90 \%$ of the tise. The 902 duration flaw for the United States east of the 100th meridian is about $0.2 \mathrm{cfs} / \mathrm{sq}$ aile and for unregulated streans is about 202 of the mean annusl flow.

Flou frequency: That disharge, averaged over some time period, that will recur at some speciflc cine Interval. This tern can refer to efther high or low flows and is expreased in many ways. For example, the 7-day, 10-year low flow is the lowest 7-day average discharge that will occur on the aversge of once every 10 years. The animan annusl average 7-day flow will be equal to or less than the 7-day, 10-year low flow at 
intervals averaging 10 years in leagth, or the probability 1 s 0.1 that the ainitur average 7-day flow in any year will be equal to or leas chan the 7-day, 10-yea: low flow. Frequency curves, giving flow frequencies, of ten use average flow periods ranging fron three days to one year and recurrence intervals from one to fifty years. Por unregulated strenes, the 7-day, 10-year low flow is about 100 of the mean sumal flow.

Host of the data published in the USCS water cupply papers provide flow data in cfs; however, studies intended for bore general use give flows in other tafte, usually allion gallow fer day (ind). The follow ing tables provide cusversion factors for the we comonly used units of volune and tlon rates.

\begin{tabular}{cll}
\multicolumn{3}{c}{ Volune } \\
\hline Cubic feet & Gellows & Acre-feet \\
\hline 1 & 7.48 & $2.30 \times 10^{-5}$ \\
0.134 & 1 & $3.07 \times 10^{-6}$ \\
43.560 & $3.26 \times 10^{5}$ & 1 \\
\hline
\end{tabular}

Flow Rates

\begin{tabular}{lcll}
\hline $\begin{array}{c}\text { Cubic feet } \\
\text { per second }\end{array}$ & $\begin{array}{c}\text { Gallons } \\
\text { per aimute }\end{array}$ & $\begin{array}{c}\text { M111ion gallows } \\
\text { per day }\end{array}$ & $\begin{array}{c}\text { Acre-feet } \\
\text { per day }\end{array}$ \\
\hline 1 & 449 & 0.646 & 1.98 \\
$2.23 \times 10^{-3}$ & 1 & $1.44 \times 10^{-3}$ & $4.76 \times 10^{-3}$ \\
1.55 & 694 & 1 & 3.07 \\
0.505 & 226 & 0.326 & 1 \\
\hline
\end{tabular}




\section{DxpDAces}

1. 0.S. Huclear Regulatory Conisalca, Buclear Enargy Center Site Survey - 1875, Whec-0001, Jamury 1976.

2. United States Water Resources Covac1l, The Uation's Hater Resources, 0.S. Covernent Printing Office, Unshington, D.C., 1968.

3. C. C. Durwe11, Mater Pollution and ELootriaity Production: The Open Cycle cooling Tower for Strwan deration - A Prelininary Evaluation, OJIh/TH-3979, Oak Ridge Hational Laboratory, Oak Ridge. Teua., October 1972.

4. W. Wollena and C. W. Bowes, the Outlook for Mater, The Jobn Hopkins Prese, Baltieore, Haryland, $197 i$.

5. U.S. Departaneat of Agriculture, the Yearbook of Agriculture 1955: Mater, U.S. Government Prz.tion Off Ice, Washington, D.C.

6. U.S. Hater Resources Counc11. Project Independenon, Watej Requiremente, Availab-lities, Constrainth, and Recommenied Isderal Antions, 0.S. Goverunent Printins Office, Unchington, D.C., Novenber 1974.

7. U.S. Envirownentel Protection Azencs. Proposed Criteria for dater Quality, wol. I, U.S. Covernment Frintios Office, Weshington, D.C.. October 1973.

8. United Engiseers and Coneructors, Heat Sink jeoign and Cost Study for Poseil and muclear Pourp PLants, MSA-1360, Decenber 1974.

9. U.S. Hater Resources Counc11, IU75 ilater Assesenent, to be publiabed.

10. Lower Miselesippl Resion Compebenelve Study Coordination Comittee, lower Miseiseippi Region Comprehenoive Study, Appeadix C, vols. I and 11, 1974.

11. Pacif 1i Morthuest River Basta Comisesion, Columbric-north Pacific Region Cimprehensive Prameurork Study, Appendix V, vols. 1 and Z, Vancouver, Washington, April 1970.

12. U.S. Army Engineer Division, Onto River, Ohio River Bcein Comprehensive Study, Appeadix C, Cinc1mane1, On10, Auguet 1966.

13. Miscour1 Basin Inter-Agency Comftee, The Missowi Rivir Banin Comprehenoive Promasork Stiudy, vol. 6, December 1971.

14. U.S. Atonic Energy Comiseion, Muclear Power Grovth, 1971-2000, UASH-1139, February 1974. 